\title{
The Emergence of the Arms Trade Treaty as a Global Norm Cluster
}

Belinda Kay Gardner

A thesis submitted in fulfilment of the requirements for the degree of Master of Arts in International Relations at Victoria University of Wellington.

June, 2011 


\section{Abstract}

The Arms Trade Treaty brings together a number of small arms control norms into one instrument and is a new initiative, which was instigated by state and NGO norm entrepreneurs. This thesis attempts to understand what has led to the emergence of these norms in the Arms Trade Treaty, in what will be termed a 'cluster' of small arms norms. Examining the small arms norms associated with the Arms Trade Treaty will explain their development and their likelihood of successfully being incorporated into this instrument.

Analysis of the development of the norms related to the Arms Trade Treaty will explore the relationship between norms, their promoters and their opponents. This thesis will do this by providing detailed analysis of the development of specific norms in a series of case studies: control over arms brokering, transfers to non-state actors and civilian possession. It will place this development within the broader context of the ATT instrument and the international society in which it is emerging into. This thesis finds that power and powerful states have a significant role to play in the emergence of norms, in some cases despite the efforts of norm promoters. Norms were not able to emerge in their original form due to the influence of powerful states, which resulted in norms evolving in different directions or not emerging at all. 


\section{Acknowledgements}

I would like to thank the following people: my family and friends for their support and encouragement; the Peace and Disarmament Education Trust for their financial assistance which enabled my field research; my supervisor Dr David Capie for his guidance and help; the Academic Council on the United Nations System for their practical assistance which enabled my field research; and Luke Roughton and Oxfam New Zealand for their invaluable time during my internship experience. 


\section{Table of contents}

The Emergence of the Arms Trade Treaty as a Global Norm Cluster

Abstract

Acknowledgements

Table of contents 4

Abbreviations 8

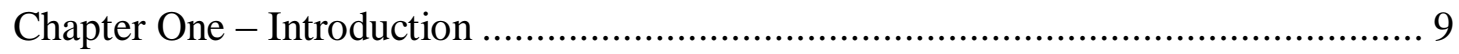

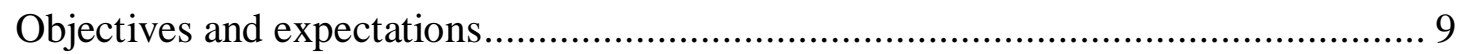

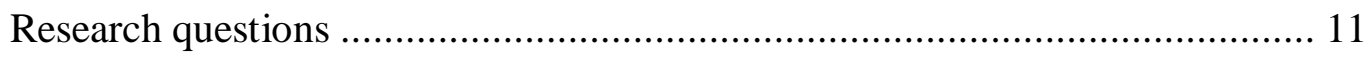

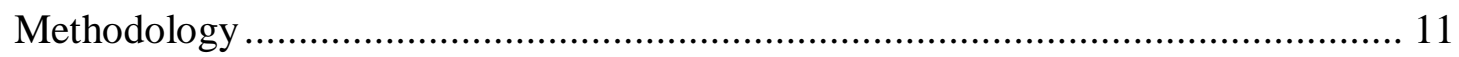

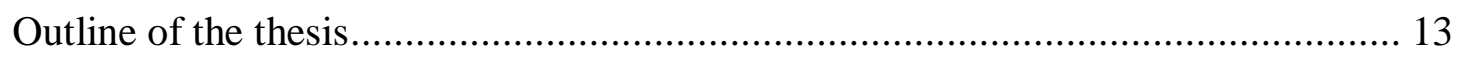

Chapter Two - A review of norms in theory and practice ................................ 14

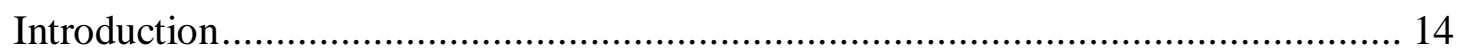

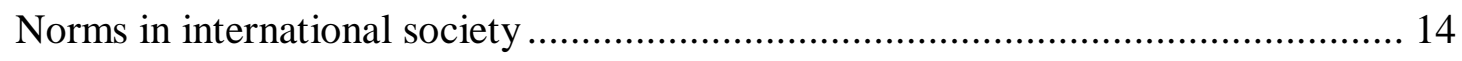

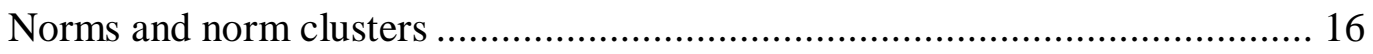

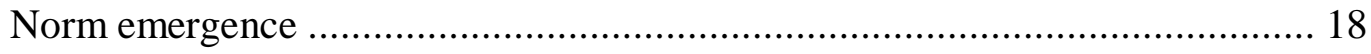

Norm diffusion and institutionalisation .................................................. 24

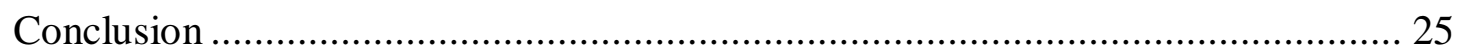

Chapter Three - The emergence of the Arms Trade Treaty norm cluster...... 26 
What is the small arms problem?

The emergence of conventional weapons controls

Norms that influenced the Arms Trade Treaty norm cluster

What are the current formal controls on small arms and light weapons?

General conventional weapons measures

The Firearms Protocol

The Programme of Action.

Specific regional agreements 38

The Arms Trade Treaty 40

The Arms Trade Treaty norm cluster

Conclusion

Chapter Four - Brokering and the Arms Trade Treaty 50

Introduction

What is brokering?

What is the norm regulating brokering in small arms?

The norm regulating brokering in relation to the Arms Trade Treaty 57

Illicit brokering 59

Conclusions 71

Chapter Five - Non-State Actors and the Arms Trade Treaty 73

Introduction 
Non-State Actor Acquisition of Small Arms and Light Weapons

Why weapons transfers to non-state actors are problematic

The development of the norm against SALW transfers to non-state actors

The norm against SALW transfers to non-state actors in the Arms Trade

Treaty 78

Preventing diversion of weapons to non-state actors 80

Authorised non-state actors versus unauthorised non-state actors.... 87

Conclusions 93

Chapter Six - Civilian Possession and the Arms Trade Treaty 95

Introduction 95

Regulating Civilian Possession of Small Arms 95

Why civilian possession of small arms needs regulation 96

The development of the norm regulating civilian possession of small arms 97

Regulating civilian possession of small arms in relation to the Arms Trade

Treaty 102

Opposition to the norm regulating civilian possession. 103

Support for the norm regulating civilian possession of small arms 109

Conclusions

Chapter Seven - Conclusions

The evolution of the Arms Trade Treaty norm cluster.

Some answers to my research questions 
Bibliography

Primary Sources . 


\section{Abbreviations}

APEC - Asia-Pacific Economic Community

ATT - Arms Trade Treaty

CAC - Control Arms Campaign

CICAD - Inter-American Drug Abuse Control Commission

CoCCW - Convention on Prohibitions or Restrictions on the Use of Certain

Conventional Weapons Which May Be Deemed to Be Excessively Injurious or to

Have Indiscriminate Effects

CGP - Consultative Group Process (of the Biting the Bullet Project)

CTOC - Convention against Transnational Organised Crime

DSAAC - Defense Small Arms Advisory Council

ECOWAS - Economic Community of West African States

EU - European Union

FARC - Fuerzas Armadas Revolucionarias de Colombia

IANSA - International Action Network on Small Arms

ICBL - International Campaign to Ban Landmines

IHL - International Humanitarian Law

IHRL - International Human Rights Law

MANPADS - Man-Portable Air Defence System

NRA - National Rifle Association of America

NRA-ILA - Institute for Legislative Action, National Rifle Association of America

NSA - Non-state actor

OAS - Organisation of American States

OSCE - Organisation for Security and Cooperation in Europe

PrepCom - Preparatory Committee

SADC - South African Development Community

SALW - Small arms and light weapons

UN - United Nations

UNIDIR - United Nations Institute for Disarmament Research

UN ROCA - United Nations Register of Conventional Arms 


\section{Chapter One - Introduction}

Armed violence has claimed hundreds of thousands of lives since the end of the Cold War. Conventional weapons, including small arms and light weapons, are increasingly acknowledged by the international community as presenting a human security issue that needs to be addressed with cooperative action. One manifestation of this has been the development of a proposal for an Arms Trade Treaty (ATT) within the United Nations, an international law which aims to regulate transfers of conventional weapons. The ATT is currently being negotiated and is due to be completed in 2012. ${ }^{1}$ The Treaty is not the only mechanism which has addressed small arms and light weapons; there are a number of norms related to the control of small arms and light weapons (SALW) which have been advanced by various sources outside the Treaty process. ${ }^{2}$ The ATT seeks to bring them together into one instrument, an effort which has obvious benefits, but also some drawbacks. This thesis attempts to understand how small arms norms emerged and to understand the impact of what I will term a 'cluster' - or interconnected set - of small arms norms on the ATT.

\section{Objectives and expectations}

This thesis explores the development of a norm cluster around the Arms Trade Treaty, seeking to understand why these norms have been associated with the Treaty and what role they will have in the future of the Treaty. The Treaty is a new initiative, prompted by state and civil society norm entrepreneurs in the field of small arms controls, but also in related fields such as peace-building, disarmament and

\footnotetext{
${ }^{1}$ The Arms Trade Treaty will alternatively be referred to by its acronym ATT.

${ }^{2}$ Small arms and light weapons will alternatively be referred to by the acronym SALW.
} 
human rights promotion. The ATT is still in the process of formation, and as such, little scholarship has been done on the emergence and diffusion of the cluster of small arms controls which are linked to it.

There is, however, substantial literature on small arms issues. Research has looked at the implementation of other small arms control mechanisms, such as the Programme of Action to Prevent, Combat and Eradicate the Illicit Trade in Small Arms and Light Weapons in all its Aspects and the Protocol against the Illicit Manufacture of and Trafficking in Firearms, Their Parts and Components and Ammunition. ${ }^{3}$ Other published work on small arms has been focussed on a specific area of arms control, such as disarmament programmes and tracing weapons ${ }^{4}$, or on a specific region such as South East Asia ${ }^{5}$, with the predominance of arms control efforts having focussed in the past on control of weapons of mass destruction or conventional weapons within a security framework. Despite a wave of norms literature published since the 1990s, there has not been enough attention paid to the way that power and powerful states contest, constrain and in some cases ultimately defeat emerging norms. In this thesis I seek to fill this gap in the academic work by looking in detail at the emergence and contestation of small arms norms in relation to the ATT. The thesis looks at the relationship between states and NGOs, arguing that whether or not particular small arms norms have been included in the Arms Trade Treaty cluster is strongly related to the efforts of strong states that either support or

\footnotetext{
${ }^{3}$ United Nations Department for Disarmament Affairs, "Programme of Action to Prevent, Combat and Eradicate the Illicit Trade in Small Arms and Light Weapons in All Its Aspects"; United Nations General Assembly, Protocol against the Illicit Manufacturing of and Trafficking in Firearms, Their Parts and Components and Ammunition, supplementing the United Nations. Hereafter these instruments will be referred to as the Programme of Action and the Firearms Protocol respectively.

${ }^{4}$ Muggah, Listening for a Change! Participatory Evaluations of DDR and Arms Reduction in Mali, Cambodia and Albania; Control Arms Campaign, Tracking Lethal Tools. Marking and Tracing Arms and Ammunition: A Central Piece of the Arms Control Puzzle.

${ }^{5}$ Capie, "Localization as Resistance: The Contested Diffusion of Small Arms Norms in Southeast Asia."
} 
object to the norm in question. It will look at the role of powerful states and rival NGOs, as well as considering the message that NGOs are promoting. By doing so, it fuses an interest in normative influence with a recognition of the role of power in international politics.

\section{Research questions}

How have small arms norms developed within the context of the Arms Trade Treaty? In seeking to answer this question, this thesis focuses primarily on three specific norms - action to address arms brokering, non-state actor acquisition of weapons and civilian possession. In the process of answering this larger question, the thesis will examine the content of these emerging norms and look at who has promoted (or opposed) them. I hope that these answers will shed light on the future direction and prospects for norms in the ATT norm cluster.

\section{Methodology}

In order to explore these issues, this thesis uses two main research methods: participant observation and content analysis. There has been a small but significant amount of academic work done in the past on the control of small arms and the norms which have arisen around it. Influential authors' works will be analysed and referenced, including academic small arms literature by scholars such as Garcia and Clarke. These authors have looked at how small arms norms have been emerging over time and on success and failure of these norms in comparison to other weapons norms. Analysis of documents from the United Nations' Institute of Disarmament Research and state submissions on a potential ATT will contribute to understanding the development of small arms norms. However, greater attention will be paid to the statements made by officials at the Preparatory Committee for the United Nations Conference on the Arms Trade Treaty in New York in July 2010 gathered during 
attendance $^{6}$, as well as documents from the second PrepCom in 2011 and past Government position papers on the Programme of Action.

States used the initial week of the PrepCom to outline their general positions on the Treaty, with chair Ambassador Roberto García Moritán establishing a basic agenda for discussing the Treaty's scope, parameters and implementation on the second day in closed sessions, despite opposition from NGOs. He allocated the remaining open sessions, which included time for civil society presentations, to discussing the elements, principles and goals of the Arms Trade Treaty. Moritán made it clear that he intended to cast a wide net with regard to what was being included in the ATT negotiations. Official documents released during the PrepCom by Moritán and his allocated 'Friends of the Chair', Ambassadors Aly, Charles and Quinlan, on these subjects will be analysed and referenced. Government position papers circulated at the PrepCom are used to inform the evaluation of state views of the norms in the Treaty. Notes taken from personal observation of states representatives at the PrepCom will also be used to form a better analysis of what states' views on the ATT are and the place of norms in the ATT cluster. This information was obtained by personal attendance at the UN PrepCom meetings and taken down as completely and objectively as possible, taking care to note stated positions on the various norms which are part of the cluster. In addition, I will offer a personal perspective on the negotiations from informal meetings with civil society representatives, including Amnesty International, IANSA and Oxfam, and state officials whom I met during breaks in official meetings at the PrepCom.

\footnotetext{
${ }^{6}$ The Preparatory Committee for the United Nations Conference on the Arms Trade Treaty was held in New York, July 12-23 2010. This was the first of three Preparatory Committees, the second and third being held in 2011, in anticipation of the 2012 United Nations Conference on the Arms Trade Treaty. Hereafter the first United Nations Preparatory Committee will be referred to as the first PrepCom, and the first 2011 PrepCom will be referred to as the second PrepCom.
} 


\section{Outline of the thesis}

The thesis has seven chapters. Following on from this introductory chapter, the next two chapters situate small arms controls in the context of international relations scholarship. Chapter two outlines the evolution of the scholarship on norms, in particular research that has identified different pathways to explain the spread of diffusion of norms. Chapter three then provides some background to small arms action, focusing on the emergence of the Arms Trade Treaty as a discrete mechanism. Chapters four, five and six then provide the empirical heart of the thesis, by looking in detail at the emergence and development of three key norms: control over arms brokering, the regulation of transfers to non-state actors and civilian possession. By focussing in depth on components of the Arms Trade Treaty as it relates to small arms, I show how small arms norms are developed, advanced and contested. Finally, the thesis concludes with answers to these questions based on the findings within, and makes some predictions about the future of the Arms Trade Treaty norm cluster. 


\section{Chapter Two - A review of norms in theory and practice}

\section{Introduction}

For most of the period leading up to the end of the Cold War, International Relations was dominated by realism and liberal institutionalism. It is only in the last decade and a half that political scientists have begun to experiment with sociological or social constructivist influences borrowed from other disciplines. The use of constructivist approaches to explain international politics has grown enormously in the last twenty years. In particular, the notion that the choices that actors make are influenced by how they perceive themselves and the world, and the influence of norms has come to have greater sway in political science. The field of norms is largely a practical one, in which a general assertion - that norms matter - is applied to a wide range of cases. One criticism directed at this scholarship is a focus on successful cases, examples where norms took hold, and ignoring cases where a norm failed to become established. ${ }^{7}$ For this reason, detailed case studies of the emergence of norms are useful, as they help to build a more accurate picture of which norms matter, why and when. This thesis uses three detailed cases of small arms control norms in the context of the Arms Trade Treaty to add to the emerging literature on norms theory. ${ }^{8}$

\section{Norms in international society}

Norms have arisen as a vehicle for understanding the motivations for decision-making in a way that rational choice theories of political science have not. During the 1980s and 1990s, several scholars undertook the study of norms in an

\footnotetext{
${ }^{7}$ Checkel, "Review: The Constructivist Turn in International Relations Theory."

${ }^{8}$ It should be noted here that the Arms Trade Treaty attempts to regulate all conventional weapons, not just small arms and light weapons. This will be explained in more detail in Chapter Three.
} 
attempt to comprehend the 'why' of political decision-making. In an era of Cold War and post-Cold War politics, states' reasoning in their international relations did not always make sense within the rational choice perspectives that were dominant at that time. It came to be theorised, by what is deemed the 'constructivist school', that people's choices are bounded by their beliefs and expectations of the world around them. Whilst variously defined as "logics of appropriateness", "standards of behaviour defined in terms of rights and obligations", or "collective expectations for the proper behaviour of actors with a given identity", the essential meaning is the same; that there are some 'standards of behaviour' - norms - which can be universal. ${ }^{9}$ The existence of these norms places a feeling of obligation on actors to comply with the new expectation, regardless of its legal standing. As Finnemore and Sikkink theorised, norms that are fully accepted are later institutionalised into law. ${ }^{10}$ In the field of arms control, scholars have increasingly turned to normative theory to explain why actors make decisions and chose courses which cannot be easily explained by other theories. This move has been accompanied by a greater interest amongst 'like-minded states' and NGOs in norm promotion and has resulted in more action by these actors to promote arms control norms. This thesis looks at normative theory in relation to small arms in the Arms Trade Treaty in general and in three specific cases, to determine how these norms are developed and advanced or defeated by the relationship between their proponents and their opponents. This

\footnotetext{
${ }^{9}$ Checkel, "Review: The Constructivist Turn in International Relations Theory"; Finnemore and Sikkink, "International Norm Dynamics and Political Change"; Florini, "The Evolution of International Norms"; Glatz, "Norm Diffusion: Top Down or Bottom-Up? Small Arms Norms in El Salvador, South Africa and on the International Level"; Krasner, International Regimes; O'Dwyer, "First Landmines, now Small Arms? The International Campaign to Ban Landmines as a Model for Small-Arms Advocacy."

${ }^{10}$ Finnemore and Sikkink, "International Norm Dynamics and Political Change," 898-899.
} 
chapter will begin with a brief overview of the scholarship on norms, before moving to apply the theory to the case studies.

\section{Norms and norm clusters}

This thesis uses Krasner's definition of norms - "standards of behaviour defined in terms of rights and obligations" - for several reasons. First, this definition is widely accepted. Second, it encompasses the way that a norm creates a commitment for actors to abide by the principles within it, and third, it reinforces the proposition that norms are actions or behaviours. However, this thesis goes further to suggest the Arms Trade Treaty is a norm cluster rather than a singular norm. ${ }^{11}$ The meaning of norm cluster here takes the simple form of 'norm' meaning "standards of behaviour defined in terms of rights and obligations" ${ }^{12}$, and 'cluster' meaning a group of related things arranged or happening together. A norm cluster is thus a collection of norms that address elements of the same issue, but which each contain individual normative obligations themselves, much like the informal definition proposed by Hetcher. ${ }^{13}$ These norms all relate to one common subject, but address different aspects of the whole problem and thus contain different standards of behaviour and obligations to fulfil. The norms within the cluster will generally, but not inevitably, be in accord, as they (may) arise from different norm entrepreneurs, platforms and concerns.

The emerging Arms Trade Treaty exists as a cluster of multiple norms. It does not outline a singular norm, nor is it an institution. Finnemore and Sikkink

\footnotetext{
${ }^{11}$ Ackerman, "The Prevention of Armed Conflicts as an Emerging Norm in International Conflict Management: The OSCE and the UN as Norm Leaders." Ackerman refers to "clusters of norms" here.

${ }^{12}$ Krasner, International Regimes.

${ }^{13}$ Hetcher, “The Music Industry's Failed Attempt to Influence File Sharing Norms," 12. The term 'norm cluster' is used in mathematics, biology, computer science and law, but each has a different meaning and none of them equate to the meaning of 'norm cluster' here.
} 
differentiate between the term 'norm', and the term 'institution', arguing that an institution puts the emphasis on the ways that the beliefs connect, rather than on the beliefs themselves. ${ }^{14}$ In a similar way, this thesis looks at a norm cluster as a set of norms which address a related issue - in this case small arms control - rather than looking at how they interrelate. For the purposes of this thesis, it is understood that the norms within the cluster might not act in coordination, but the focus is on the development of the Arms Trade Treaty. A norm cluster differs from a regime in that a regime consists of more than just norms. According to Haas, a regime is "sets of implicit or explicit principles, norms, rules and decision-making procedures around which actors' expectations converge in a given area of international relations". ${ }^{15}$ Rittberger and Mayer add that "regimes can be identified by the existence of explicit rules which are referred to in an affirmative manner by governments, even if they are not scrupulously observed". ${ }^{16}$ Given this, it is possible to say that a norm cluster is less formal than a regime, particularly considering Rittberger and Mayer choose to specify explicit rules and principles. Nor is a norm cluster an international institution, which is classified as "persistent and connected sets of rules (formal and informal) that prescribe behavioural roles, constrain activity, and shape expectations", and includes international and transnational organisations, conventions and international regimes. ${ }^{17}$ Again, this is a more formal and established concept than that of a norm cluster. A norm cluster could be nascent, be in the process of diffusion or be institutionalised, just as a singular norm might be. In this context, there are several norms relating to the control of arms which are under

\footnotetext{
${ }^{14}$ Finnemore and Sikkink, "International Norm Dynamics and Political Change," 891.

${ }^{15}$ Haas, "Words Can Hurt You; Or, Who Said What to Who About Regimes," 211.

${ }^{16}$ Rittberger and Mayer, Regime Theory and International Relations, 28.

${ }^{17}$ Ibid., 28-29.
} 
consideration for addition to the Arms Trade Treaty text, including rules around tackling illicit brokering, surplus stock destruction, regulation of civilian possession, and prohibiting transfers to non-state actors. ${ }^{18}$

\section{Norm emergence}

Finnemore and Sikkink's influential article, 'International Norm Dynamics and Political Change' has continued to resonate among scholars since its publication in $1998 .{ }^{19}$ It outlines a theory of norm creation that seeks to explain when and how new ideas and 'logics' came to exist. Whilst it is not the only theory of norm emergence, it is the dominant one. ${ }^{20}$ The authors look at gaps and puzzles in international politics, behaviours and decisions that realist and liberal theories cannot adequately explain. The resulting argument puts particular emphasis on the context in which decision-making occurs, and how it places limits on what choices appear available to decision-makers. How they understand the problem and see themselves in relation to others shapes their responses. New norms emerge from these situations, generally as a response to a perceived problem or when a situation changes making the normative guidelines less relevant. In line with this, Nadelmann's second stage in the creation of a global prohibition regime describes this change as the point when previously acceptable behaviour becomes

... redefined as a problem and as an evil - generally by international legal scholars, religious groups, and other moral entrepreneurs - and explicit government involvement in the activity is gradually delegitimized ... ${ }^{21}$

\footnotetext{
${ }^{18}$ See for example Garcia, Small Arms and Security: New Emerging International Norms.

${ }^{19}$ Finnemore and Sikkink, "International Norm Dynamics and Political Change."

${ }^{20}$ A simple search of the Google Scholar database for "norm emergence" shows over 1900 articles which cite Finnemore and Sikkink’s 'International Norm Dynamics and Political Change'. Comparatively, Ann Florini's article 'The Evolution of International Norms' has been cited by over 200 other articles. [March 2011]

${ }^{21}$ Nadelmann, "Global Prohibition Regimes: the Evolution of Norms in International Society," 485.
} 
It is this period of change and redefinition that signals the emergence of a new norm into international society.

The main hypothesis of Finnemore and Sikkink's article is that norms emerge via a process of persuasion, before reaching a critical point and 'cascading' into general use through socialisation and then internalisation. ${ }^{22}$ Stage one is norm emergence, when the norm is nascent and is marginally supported. Through persuasion, actors are able to convince a number of other actors to support the norm, leading to a "tipping point". ${ }^{23}$ Once a critical mass of actors support the norm - this can be a large number or a smaller number plus "critical" actors ${ }^{24}$ - the norm moves into the second stage, a period of strengthening, socialisation and diffusion. ${ }^{25}$ The final stage comprises of acceptance and internalisation of the new norm. ${ }^{26}$ Through their research, these authors determined that the mechanisms and actors differed at each of the three stages they identify. This has far-reaching consequences for both the study and practice of norms and norm change, as it seems that both during and after the initial phase of norm creation, the norm is reinforced and solidified by distinct devices. The subsequent stages of norm emergence follow a pattern of socialisation and institutionalisation, although the emergence of a norm does not guarantee its success. ${ }^{27}$

In the initial stage, the norm is built through the work of a 'norm entrepreneur'. This actor is responsible for the initial dissemination of the new norm,

\footnotetext{
${ }^{22}$ Finnemore and Sikkink, "International Norm Dynamics and Political Change."

${ }^{23}$ Ibid., 896-901.

${ }^{24}$ Ibid., 901.

${ }^{25}$ Ibid., 902-904.

${ }^{26}$ Ibid., 904-905.

${ }^{27}$ Finnemore and Sikkink, "International Norm Dynamics and Political Change"; Garcia, Small Arms and Security: New Emerging International Norms, pt. 3; Hetcher, "The Music Industry's Failed Attempt to Influence File Sharing Norms."
} 
using the influence that they have with others to establish it as both plausible and credible. Finnemore and Sikkink argue that this process occurs because a norm entrepreneur or group of entrepreneurs feels strongly about an idea. It may be an idea that they have taken on as an issue $d u$ jour; or it may be a new idea that transpires as a response to discussions, practices and interactions. They cite women's suffrage as an example of norm emergence based on the activity of norm entrepreneurs. ${ }^{28}$ The idea that women should have the vote was alarming and novel to some, but through the persistence of agents, it became more widespread and finally universal. Importantly, "new norms never enter a normative vacuum" 29 ; in cases of norm emergence, there is always competition between the old custom and the proposed change. It is the nature of the world, and of people, to compete and to question the appropriateness of ideas and practices. Finnemore and Sikkink note that the motivations of norm entrepreneurs can be described as "empathy, altruism and ideational commitment". ${ }^{30}$ They are driven to promote new norms, even at risk to themselves as changing the logic of appropriateness may involve, improper or 'inappropriate' actions. The norm promoters use praise, demonstration, and in some cases negative incentives, to convince other actors that these norms have merit. ${ }^{31}$ This may require some changes to the norm. When this happens, the main actors may attempt to 'frame' the issue in a way that the community will understand by deliberately highlighting certain aspects of the emerging norm which have similar characteristics to pre-existing beliefs and understandings. ${ }^{32}$ In grafting cases, the

\footnotetext{
${ }^{28}$ Finnemore and Sikkink, "International Norm Dynamics and Political Change," 897.

${ }^{29}$ Ibid.

${ }^{30}$ Ibid., 898.

${ }^{31}$ Nevers, "Imposing International Norms: Great Powers and Norm Enforcement."

${ }^{32}$ Finnemore and Sikkink, "International Norm Dynamics and Political Change," 897; Payne, "Persuasion, Frames and Norm Construction"; Price, "A Genealogy of the Chemical Weapons Taboo"; Snow et al., "Frame Alignment Processes, Micromobilization, and Movement Participation."
} 
norm is associated or aligned with a current norm, usually within a similar issue area. $^{33}$

The second main component of norm emergence, according to these authors, is an "organisational platform". ${ }^{34}$ All of the examples that Finnemore and Sikkink document in their article show a normative entrepreneur working within or through an organisation. This organisation provides a starting point for the promotion and establishment of the new norm. It may already exist, or it may be created specifically for the purpose of changing the existing standards and logics. Without this institutional and informational backing, it is harder for these entrepreneurs to have the contemporary norm considered seriously by the international community. Within the organisational setting, the idea is able to be studied and shaped into a feasible policy. ${ }^{35}$ This in turn strengthens the support base of the norm, including support from states.

Other, arguably less influential, theories of norm emergence challenge the norm creation process that Finnemore and Sikkink laid out. There are slight variations within these alternative models but for the most part, the norm remains intact and is accepted in that form by other actors. The nuances in these models include examining what kind of persuasion is used, how strong it is and which states or actors are involved ${ }^{36}$, and when and why an international norm is introduced by actors, domestic or international. ${ }^{37}$ Each of these studies helps to advance

\footnotetext{
${ }^{33}$ Acharya, "How Ideas Spread: Whose Norms Matter? Norm Localization and Institutional Change in Asian Regionalism"; Price, "A Genealogy of the Chemical Weapons Taboo"; Price, "Reversing the Gun Sights: Transnational Civil Society Targets Land Mines."

${ }^{34}$ Finnemore and Sikkink, "International Norm Dynamics and Political Change,” 899.

${ }^{35}$ Ibid., 899-900.

${ }^{36}$ Nevers, "Imposing International Norms: Great Powers and Norm Enforcement."

${ }^{37}$ Checkel, "Norms, Institutions, and National Identity in Contemporary Europe"; Cortell and Davis Jr, "How Do International Institutions Matter? The Domestic Impact of International Rules and Norms"; Erickson, "When Do the Takers Become the Makers? The Promotion of 'Responsible Arms
} 
understanding of how normative change occurs, when the norm in question appears to be universal enough that it needs no alteration to fit into various contexts. Clarke convincingly argues that the clarity of the norm content is important to the successful emergence of a norm. ${ }^{38}$ If a norm lacks clarity, its message is not robust, understandable or simple to communicate to audiences and therefore easy for opponents to defeat. Nadelmann considers the emergence of norms by looking at "global prohibition regimes", and the reasons why they emerge. ${ }^{39}$ Global prohibition regimes are necessitated by the inability of states to curtail these undesirable actions individually or bilaterally and often arise where there are inadequate resources or issues of sovereignty surrounding the criminal activity which can be solved by creating a multilateral initiative. ${ }^{40}$ Ultimately, he concludes that regime creation depends on what national legislation is in place and the ability of moral entrepreneurs to build a strong case for such prohibition.

Florini's approach to norms takes a different angle in that it is based on the scientific theory of evolution, and the concept of 'survival of the fittest' ${ }^{41}$ This biological slant to normative theorising, despite obvious differences, proposes a similar line of thought in some ways to that of Finnemore and Sikkink. Both theories argue that norms emerge from a larger field of standards and beliefs, and that a new norm must compete with other current and new norms to 'prove its worth'. Florini's evolutionary model takes the view that

Trade' Norms"; Finnemore and Sikkink, "International Norm Dynamics and Political Change"; Florini, "The Evolution of International Norms"; Nadelmann, "Global Prohibition Regimes: the Evolution of Norms in International Society."

${ }^{38}$ Clarke, Transnational Advocacy Coalitions and Human Security Initiatives: Explaining Success and Failure.

${ }^{39}$ Nadelmann, "Global Prohibition Regimes: the Evolution of Norms in International Society."

${ }^{40}$ Ibid., 481.

${ }^{41}$ Florini, "The Evolution of International Norms." 
... norms, like genes, are instructional units. These units influence the behaviour of their host organisms. And norms, like genes, are "contested" - that is they are in competition with other norms or genes ... 42

In this article, Florini argues that norms are inherited via a cultural rather than genetic transmission process, and that they represent a narrower category than merely behaviour that is physically possible, which she terms "conceivable behaviour". ${ }^{43}$ Put simply, some options appear untenable, improper or merely unlikely to recipients. She proposes that norms emerge in the same way that genes do, which is that genes undergo a test of 'fitness' over time, determined by how well the gene reproduces, its ability to survive, and how well it suits its environment. ${ }^{44}$ The fact that the content of genes can alter results in the evolution of genes and this evolution only happens when there is a difference between the content of the genes, there is the ability to reproduce, and there is competition between the genes. ${ }^{45}$ Florini contends that norms act in the same way as genes.

In considering the emergence and diffusion of a norm cluster, Finnemore and Sikkink's work is more relevant to this thesis than these other theories for several reasons. Their theory covers the full range of norm emergence, from the birth of the norm to institutionalisation, in a way that other theories have not done. They allow for both states and non-state actors to have agency. Nadelmann's theory focuses on regimes, which differ from norms - and norm clusters - too much to be relevant, although it offers important insights into the later institutionalisation of norms. Finally, Florini has used a theory of scientific evolution to explain the emergence of norms, but it fails to adequately explain how there come to be differences between

\footnotetext{
${ }^{42}$ Ibid., 364.

${ }^{43}$ Ibid., 366. Emphasis in the original.

${ }^{44}$ Ibid., 368.

${ }^{45}$ Ibid., 369.
} 
the genes or norms, where the new idea specifically originates from. The reason for the surfacing of new norms is crucial for understanding who is supporting them and why. For these reasons, Finnemore and Sikkink's theory is the most useful for this thesis.

In critical essays, both Raymond and Legro argue that the way in which norms have been approached undermines the quality of the field of normative theory. ${ }^{46}$ Legro complains that authors have focussed on proving that norms "matter", rather than on the content or the reasons why they matter. ${ }^{47} \mathrm{He}$ asserts that this misinterpretation of the field has led to attributing an effect to a normative cause, without further exploration ${ }^{48}$, and Raymond notes that it can be difficult to measure the effect of a norm. ${ }^{49}$ Legro believes that this tautology lends itself to overlooking alternative explanations, and to a predisposition to the study of 'successful' norms. ${ }^{50}$

\section{Norm diffusion and institutionalisation}

Norm diffusion occurs when enough actors have accepted that the new norm is valid and more actors take up the new norm, accepting the limits and changes to behaviour it entails. According to Finnemore and Sikkink, this diffusion comes after a certain point in norm emergence, and results in a "cascade" of actors recognising the norm. ${ }^{51}$ It is after this diffusion that the new norm moves into a new period in

\footnotetext{
${ }^{46}$ Legro, "Which Norms Matter? Revisiting the 'Failure' of Internationalism"; Raymond, "Problems and Prospects in the Study of International Norms."

${ }^{47}$ Legro, "Which Norms Matter? Revisiting the 'Failure' of Internationalism,” 31-32.

${ }^{48}$ Ibid., 33-34.

${ }^{49}$ Raymond, "Problems and Prospects in the Study of International Norms," 219.

${ }^{50}$ Checkel also subscribes to these criticisms of normative theory. Checkel, "Review: The Constructivist Turn in International Relations Theory"; Checkel, "Norms, Institutions, and National Identity in Contemporary Europe."

${ }^{51}$ Finnemore and Sikkink, “International Norm Dynamics and Political Change,” 895-896, 901-902.
} 
which it is accepted by actors as the new custom and internalised by them. ${ }^{52}$ Norms are internalised by the actors of the society as the accepted way of behaving and breaches of the new norm are rare. This constitutes the full and successful emergence of a norm into international society. As a norm cluster operates in a very similar way, the cluster can also be institutionalised into law, however as the norms emerge and develop within the cluster, the cluster may not remain intact or unchanged.

\section{Conclusion}

This chapter has provided a survey of the norms literature and set out how norms emerge, using the framework of the norm lifecycle developed by Finnemore and Sikkink. The emergence of a norm is seen by the promotion of a new norm by a norm entrepreneur, using an organisational platform. The norm appears amid competition with other ideas, and has to appeal to the other actors in the system.

Once a significant number of actors accept the new norm, it cascades into common use, and diffuses throughout society. This distribution occurs in one of three ways: promotion of the norm 'as is', norm framing or grafting, or localisation of the norm. For the purpose of this thesis, the concept of a norm - a standard of behaviour defined in terms of rights and obligations - is expanded into the concept of a norm cluster. A norm cluster operates in much the same way as a norm, and can also be incorporated and institutionalised into international law i.e. legalised, in the final stage of the norm life cycle. The next chapter will explore the history and emergence of the Arms Trade Treaty norm cluster and its contents, setting the scene for a detailed examination of its development and diffusion.

\footnotetext{
${ }^{52}$ Ibid., 902-905.
} 


\section{Chapter Three - The emergence of the Arms Trade Treaty norm cluster}

\section{Introduction}

This chapter looks at the origins of the Arms Trade Treaty, to understand what the Treaty norm cluster consists of, and how it relates to small arms. The chapter will begin with a synopsis of the small arms problem before continuing on to explain why the notion of small arms controls emerged as an international issue and to explore what ideas inform these controls. The chapter examines other normative influences on the development of the ATT, such as the evolution of the ban on landmines. The chapter will then briefly discuss the current small arms controls, before moving on to the evolving content of the ATT norm cluster itself. The various norms that make up the norm cluster of the ATT will be set out and examined in more detail, as they relate to the broader issue of small arms and light weapons. Understanding the content of the cluster provides insight into why states might be supportive of the cluster, or of specific aspects of it. This will bring us to a point where we can examine the specific engagement of states with the Arms Trade Treaty, and what that means for its future: institutionalisation or implosion.

\section{What is the small arms problem?}

The impact of armed violence, using small arms, on communities and nations is devastating. ${ }^{53}$ While the exact numbers are debated, thousands of people die each year from firearms-related deaths. There is confusion because the research done is often related to 'guns' or 'firearms' and not strictly designated as 'small arms and

\footnotetext{
${ }^{53}$ The Geneva Declaration on Armed Violence and Development is aimed at highlighting the adverse effects of armed violence perpetrated using SALW by linking human suffering to conflict and to the associated effects on socio-economic development. Geneva Declaration Secretariat, "The Geneva Declaration on Armed Violence and Development."
} 
light weapons', which is a specific definition. ${ }^{54}$ This being the case, it is hard to say with any certainty how many deaths and injuries are caused each year by small arms but the research done on 'firearms' suggests that it is in the tens of thousands. ${ }^{55}$ The effects of small arms use - lethal and non-lethal - results in damage to human security, whereby people feel unsafe about their economic, health and political prospects. ${ }^{56}$

The problems associated with armed violence involving these types of weapons are clear. Their presence raises the stakes in any confrontation to a lethal level. Injuries and near-fatalities from small arms fire are potential and real dangers. Firearms are used to commit crimes, either as a threat or as part of the crime. Cook and Ludwig argue that, in the US, firearms are commonly used in crimes and that the result is more homicides and/or injuries related to firearms use..$^{57}$ The threat of the use of small arms can be used to achieve compliance with the user's demands, in cases of domestic and intimate partner violence, and in other crimes such as robberies, assaults and sexual crimes. ${ }^{58}$ Firearms are increasingly used in cases of family violence and intimate partner violence. ${ }^{59}$ Interpersonal violence related to these types of weapons takes many forms, and can have a variety of outcomes including death, but may also mean a loss of physical mobility due to injury, or a

\footnotetext{
${ }^{54}$ In this thesis I will refer to firearms specifically as a sub-category of small arms and light weapons, for example when related to research done on firearms, not as interchangeable terms. United Nations General Assembly, General and Complete Disarmament: Small Arms (Report of the Panel of Governmental Experts on Small Arms), 11-12.

${ }^{55}$ Geneva Declaration Secretariat, The Global Burden of Armed Violence; Richmond, Cheney, and Schwab, "The Global Burden of Non-Conflict Related Firearm Mortality."

${ }^{56}$ Graduate Institute of International and Development Studies, Small Arms Survey 2002: Counting the Human Cost, chap. 5.

${ }^{57}$ Ludwig and Cook, "Public Policy Perspectives: Principles for Effective Gun Policy."

${ }^{58}$ These types of use of small arms are in fact considered 'misuse' and therefore criminal.

${ }^{59}$ Wetzels, "Family Violence in the United States and Abroad, Guns at Home, Guns on the Street: An International Perspective."
} 
loss of sexual health. These experiences and other uses of small arms also impact on the mental health of the victim and the victim's family, undermining human security further.

Organised criminal groups also use small arms to destructive effect, as evidenced by the high levels of firearms homicide in countries like Brazil and Colombia. ${ }^{60}$ The 2010 Small Arms Survey reports on the possession and use of small arms by gangs and armed groups, noting that it is very difficult to count the number of weapons held by these entities. ${ }^{61}$ Inter-gang and intra-gang conflict often results in casualties as the newspapers of the world can attest to, regardless of the country. Armed groups are somewhat different from gangs in that perception of their behaviour and use of weapons can depend on the group in question, the information source, and what 'cause' the group fights for. As the 2010 Small Arms Survey comments, sometimes armed groups are called "community defence forces" and sometimes they are called "terrorists". ${ }^{22}$

The modern face of warfare is changing and conflicts are now no longer only state versus state involving state-based defence forces. ${ }^{63}$ Non-state armed groups are now participating in battles with state forces and each other. The 1990s was a decade of wars between states and non-state actors, including a number of deadly conflicts in Rwanda, the former Yugoslavia, Iraq, Pakistan, Somalia, the Democratic Republic of Congo, Algeria, Mexico and the Chechen region among others. ${ }^{64}$ These and other

\footnotetext{
${ }^{60}$ Godnick and Vàzquez, Small Arms Control in Latin America.

${ }^{61}$ Graduate Institute of International and Development Studies, Small Arms Survey 2010: Gangs, Groups, and Guns, 102, 109-113. They estimate that out of around 650 million civilian owned weapons, between 3 and 11 million are in the hands of gangs and non-state groups.

${ }^{62}$ Ibid., 87-88.

${ }^{63}$ The Uppsala Conflict Data Program (UCDP) is a comprehensive source for conflict data and information, at http://www.pcr.uu.se/research/UCDP/. Last accessed on August 23, 2010.

${ }^{64}$ Uppsala Conflict Data Program (UCDP), at http://www.pcr.uu.se/research/UCDP/.
} 
wars were a mix of inter-state and intra-state violence, fought over territory, power, ethnicity, religion and resources. SALW are used by military forces and by nonmilitary forces to the same effect, as they are portable, easy-to-use and long-lasting. For as long as they are maintained in a reasonable state and there is corresponding ammunition, small arms remain useful. In many regions, small arms from the Cold War era are making their way from conflict to conflict as these stockpiles are gradually dispersed throughout the world ${ }^{65}$ In particular both Africa and Latin America have been devastated by the availability of these types of weapons, suffering from conflict, irresponsible use and threat of weapons to commit atrocities, repression, and violation of human rights. Numerous Amnesty International reports, including the most recent global report, testify to the violence which is both perpetrated and assisted by small arms in these areas and throughout the world. ${ }^{66}$ Access to these weapons by non-state armed groups is facilitated by black markets which supply globally. For these reasons, these two regions have been at the forefront of efforts to control arms at all levels.

\section{The emergence of conventional weapons controls}

The unrestricted availability of small arms and other conventional weapons contributed to a series of conflicts, particularly in the 1990s, both inflaming them and prolonging them. One of the consequences of this was a focus on the need to control the proliferation of all types of conventional weapons and to address root causes of such human insecurity. Former Secretary-General of United Nations, Boutros Boutros-Ghali, released his report An Agenda for Peace: Preventive Diplomacy, Peacemaking and Peace-keeping in which he used the phrase 'human

\footnotetext{
${ }^{65}$ Boutwell and Klare, "A Scourge of Small Arms."

${ }^{66}$ Amnesty International, Amnesty International Report 2010: State of the World's Human Rights.
} 
security' to describe the state in which these conflict-affected people ought to be able to live ${ }^{67}$ The control of small arms has therefore been influenced by human security because of the use of these weapons in conflict and the subsequent disarmament. Security sector reform and the demobilisation, demilitarisation and reintegration of combatants are now commonly used to build peace in regions which have experienced armed conflict, as it contributes to confidence-building and the creation of trust and peace between previously combatant groups. ${ }^{68}$ Weapons destruction is not only undertaken in post-conflict situations but also in states and regions where there is political will to do so in the face of proliferation of small arms creating insecurity, such as those undertaken successfully in Brazil and Albania. ${ }^{69}$

\section{Norms that influenced the Arms Trade Treaty norm cluster}

Other security norms have preceded the Arms Trade Treaty and thus have had an influence on its development. ${ }^{70}$ In this section, I briefly examine two different security norms which were institutionalised into international law, in order to explore what are the crucial elements for the legalisation of security norms.

\section{The norm against the use of landmines}

The path of the normative prohibition on anti-personnel landmines (AP landmines) and cluster munitions becoming law is quite similar, and very relevant to

\footnotetext{
${ }^{67}$ Boutros-Ghali, An Agenda for Peace: Preventive Diplomacy, Peacemaking and Peace-keeping. Report of the Secretary-General pursuant to the statement adopted by the Summit Meeting of the Security Council on 31 January 1992.

${ }^{68}$ Demobilisation, demilitarisation and reintegration is commonly referred to as DDR.

${ }^{69}$ Karp, Surplus Small Arms in South America; Muggah, Listening for a Change! Participatory Evaluations of DDR and Arms Reduction in Mali, Cambodia and Albania.

${ }^{70}$ Garcia, "Norm Building in the Evolution of the Control of Small Arms in the International Agenda."
} 
the control of SALW as will be seen in the following chapters. ${ }^{71}$ Both norms were driven in large part by the efforts of non-state actors, either NGOs or IOs, and states then took up the challenge of banning the use of these weapons. In the case of AP landmines, there were domestic groups addressing the public and their state officials on behalf of victims as early as $1991 .^{72}$ The International Committee of the Red Cross was also involved in information dissemination and public campaigning for the use of AP landmines to end, as the casualties of these deadly weapons were increasing, and increasingly civilian in nature. ${ }^{73} \mathrm{~A}$ transnational civil society network, called the International Campaign to Ban Landmines (ICBL) was formed, and was crucial to the success of the ban as it was able to maintain momentum and pressure on states to produce an effective prohibition regime. ${ }^{74}$ O'Dwyer also theorises that the changed geopolitical setting was vital to the success of the campaign on states, as it enabled the move to majority voting within the Ottawa Process and a changed focus on human security rather than national security ${ }^{75}$, which saw states sign up to a prohibition on these weapons in $1997 .{ }^{76}$ Price and Clarke contend that the successful institutionalisation of the normative prohibition against

\footnotetext{
${ }^{71}$ Anti-personnel landmines and cluster munitions are two separate weapons, although they are both explosive in nature. For a description of the difference between them, see the Landmine Monitor website, http://www.the-monitor.org/index.php/LM/The-Issues/FAQs\#23852. Last accessed on August 30, 2010. Anti-personnel landmines will hereafter be referred to as AP landmines.

${ }^{72}$ Price, "Reversing the Gun Sights: Transnational Civil Society Targets Land Mines," 620; The International Campaign to Ban Landmines, "Mine Ban Treaty: Ban History." The AP landmine prohibition is also referred to as the Mine Ban Treaty.

${ }^{73}$ Price, "Reversing the Gun Sights: Transnational Civil Society Targets Land Mines."

${ }^{74}$ Clarke, Transnational Advocacy Coalitions and Human Security Initiatives: Explaining Success and Failure; O’Dwyer, "First Landmines, now Small Arms? The International Campaign to Ban Landmines as a Model for Small-Arms Advocacy"; Price, "Reversing the Gun Sights: Transnational Civil Society Targets Land Mines."

${ }^{75}$ O’Dwyer, "First Landmines, now Small Arms? The International Campaign to Ban Landmines as a Model for Small-Arms Advocacy," 78-79. See also Garcia, "Norm Building in the Evolution of the Control of Small Arms in the International Agenda."

${ }^{76}$ The International Campaign to Ban Landmines, "Mine Ban Treaty: Ban History"; United Nations General Assembly, Convention on the Prohibition of the Use, Stockpiling, Production and Transfer of Anti-Personnel Mines and on Their Destruction (Ottawa Convention).
} 
AP landmines was due to effective information dissemination, moral persuasion, and grafting of the norm onto other security norms by norm entrepreneurs of the ICBL. ${ }^{77}$ The ICBL was able to create political and virtual spaces in which to promote the ban on AP landmines and reconstitute them as a problem, which contributed to the successful achievement of the Mine Ban Treaty.

\section{The norm against the use of cluster munitions}

The road to the 2008 Convention on Cluster Munitions was broadly similar to that of the development of the AP landmine prohibition from norm to international law. The Oslo Process was prompted by both the 2003 formation of the Cluster Munition Coalition and the coalescing of a group of 'like-minded states'. It moved debate outside the official fora, after the failure to address the issue of cluster munitions within the Convention against Certain Conventional Weapons ${ }^{78}(\mathrm{CoCCW})$ in 1995 and other much earlier (failed) attempts. ${ }^{79}$ Norway and certain other states became norm entrepreneurs in conjunction with these NGO coalitions, pushing for a number of international and regional conferences which were attended by many states. These conferences successfully helped to build and maintain the impetus of the campaigning so that a treaty was created in $2008^{80}$, and the Convention on Cluster Munitions came into force on August 1, 2010. ${ }^{81}$ This anti-cluster munitions

\footnotetext{
${ }^{77}$ Clarke, Transnational Advocacy Coalitions and Human Security Initiatives: Explaining Success and Failure; Price, "Reversing the Gun Sights: Transnational Civil Society Targets Land Mines."

${ }^{78}$ United Nations General Assembly, Convention on Prohibitions or Restrictions on the Use of Certain Conventional Weapons Which May Be Deemed to Be Excessively Injurious or to Have Indiscriminate Effects (and Protocols). Hereafter referred to by its acronym CoCCW.

${ }^{79}$ Corsi, "Towards Peace Through Legal Innovation: The Process and the Promise of the 2008 Cluster Munitions Convention"; The Cluster Munition Coalition, "The Problem: What is the Oslo Process?"; The International Campaign to Ban Landmines, "Convention on Cluster Munitions: Ban History."

${ }^{80}$ Corsi, "Towards Peace Through Legal Innovation: The Process and the Promise of the 2008 Cluster Munitions Convention"; The Cluster Munition Coalition, "The Problem: What is the Oslo Process?"; The International Campaign to Ban Landmines, "Convention on Cluster Munitions: Ban History."

${ }^{81}$ The Cluster Munition Coalition, "The Problem: What is the Oslo Process?"; The International Campaign to Ban Landmines, "Convention on Cluster Munitions: Ban History."
} 
norm developed via norm promotion and framing, and Corsi notes that it both built on and contributed to norms of international human rights and humanitarian law related to indiscriminate weapons.$^{82}$ Corsi argues that norm entrepreneurs were able to effectively link the proposed ban on cluster munitions to these established norms and to the institutionalisation of the ban on AP landmines.

\section{What are the current formal controls on small arms and light weapons?}

Small arms and light weapons come under a number of international rules in a general sense, as they fall into the category of conventional weapons, however no attempt to address small arms specifically until recently. Because nascent small arms norms build on the foundation of conventional weapons controls to some extent, this section will briefly outline these conventional weapons controls before looking at those specific attempts to control the transfer and acquisition of small arms.

\section{General conventional weapons measures}

In 1991, the UN Register of Conventional Weapons (UN ROCA) was created as a voluntary reporting mechanism to improve transparency in the trade of weapons between states and to prevent the stockpiling of weapons. It has seven categories and includes most types of conventional weapons in existence at that time. ${ }^{83}$ Reporting to the UN ROCA was part of the response to "the danger of increasing illicit and covert arms trafficking"; however states have never universally, comprehensively or consistently reported to the UN ROCA ${ }^{84}$ This indicates that its usefulness in

\footnotetext{
${ }^{82}$ Corsi, "Towards Peace Through Legal Innovation: The Process and the Promise of the 2008 Cluster Munitions Convention."

${ }^{83}$ United Nations General Assembly, General and Complete Disarmament: Transparency in Armaments, para. 7. The seven categories are outlined in the Annex, being: Battle Tanks; Armoured Combat Vehicles; Large Calibre Artillery Weapons; Combat Aircraft; Attack Helicopters; and Warships.

${ }^{84}$ Ibid., para. 4c.
} 
controlling the trade in conventional weapons has been limited and it must also be noted that although small arms are considered 'conventional', they are not accounted for within the UN ROCA. At the same time, Resolution 46/36 acknowledges the "human suffering" caused by actions fuelled with illicit weapons. ${ }^{85}$

Since the establishment of the UN ROCA however, a number of other initiatives have been undertaken in the area of controlling the trade in small arms and light weapons. In 1995, the United Nations General Assembly asked the SecretaryGeneral to establish a group to look into

... (a) The types of small arms and light weapons actually being used in conflicts being dealt with by the United Nations;

(b) The nature and causes of the excessive and destabilizing accumulation and transfer of small arms and light weapons, including their illicit production and trade;

(c) The ways and means to prevent and reduce the excessive and destabilizing accumulation and transfer of small arms and light weapons, in particular as they cause or exacerbate conflict ... ${ }^{86}$

This was in response to a number of conflicts in the world which the United Nations was involved with, but particularly in regard to the situation in Africa. It is also the first time that small arms were addressed in substance in this forum. Resolution 50/70 resulted in the creation of a Group of Governmental Experts on the question of small arms, which reported back in 1997 that there was indeed a need to continue looking at the proliferation of small arms and its effects. ${ }^{87}$ After that time, the United Nations kept itself regularly updated on the global situation regarding small arms and

\footnotetext{
${ }^{85}$ United Nations General Assembly, General and Complete Disarmament: Transparency in Armaments; United Nations General Assembly, Report of the Disarmament Commission (Guidelines for International Arms Transfers in the Context of General Assembly Resolution 46/36 H of 6 December 1991).

${ }^{86}$ United Nations General Assembly, General and Complete Disarmament: Small Arms.

${ }^{87}$ United Nations General Assembly, General and Complete Disarmament: Small Arms (Report of the Panel of Governmental Experts on Small Arms). This report will be referred to as the Panel of Experts Report.
} 
light weapons. ${ }^{88}$ Following this report, a meeting of NGOs was held in 1998 on the possibility of creating an instrument on SALW led by the now seasoned advocate against landmines, former Canadian Foreign Minister Lloyd Axworthy. ${ }^{89}$ While this instigated a more serious NGO effort to campaign on the issue, it was immediately apparent that this was a very different fight to the anti-land mines campaign.

Other tools of armed violence prevention through the United Nations have been the CoCCW and its associated Protocols ${ }^{90}$, which uphold the Geneva Conventions. ${ }^{91}$ Weapons which are indiscriminate are prohibited. The CoCCW specifically refers to non-detectable fragments, mines, incendiary weapons, blinding laser weapons and explosive remnants of war. ${ }^{92}$ However small arms and light weapons are not considered to be excessively harmful and most small arms and light weapons are discriminate due to their scopes or guidance systems.

\section{The Firearms Protocol}

In 2001, the United Nations made its first attempt to address the proliferation of SALW and their effects using legislation. Several supplementary protocols were added to the Convention against Transnational Organised Crime (CTOC) ${ }^{93}$, one of

\footnotetext{
${ }^{88}$ See for example the relevant sections of the resolutions on General and Complete Disarmament, United Nations General Assembly Resolutions 51/45 (1996), 52/38 (1998), 53/77 (1999), 54/54 (2000), 55/33 (2001), 56/24 (2002). After 2001, small arms were dealt with more specifically in relation to other measures taken at that time.

${ }^{89}$ Lumpe, "Curbing the Proliferation of Small Arms and Light Weapons."

${ }^{90}$ United Nations General Assembly, Convention on Prohibitions or Restrictions on the Use of Certain Conventional Weapons Which May Be Deemed to Be Excessively Injurious or to Have Indiscriminate Effects (and Protocols).

${ }^{91}$ United Nations General Assembly, Geneva Conventions (and Additional Protocols).

${ }^{92}$ United Nations General Assembly, Convention on Prohibitions or Restrictions on the Use of Certain Conventional Weapons Which May Be Deemed to Be Excessively Injurious or to Have Indiscriminate Effects (and Protocols). Protocols 1-5.

${ }^{93}$ United Nations General Assembly, Convention against Transnational Organised Crime. Hereafter referred to by its acronym CTOC.
} 
which was the Firearms Protocol. ${ }^{94}$ The Firearms Protocol is a legally binding instrument which criminalises any illegal manufacturing or trafficking of firearms and any removal or change to identification marks on the weapons, as well as requiring Party States to establish export licence systems. ${ }^{95}$ The Firearms Protocol is reasonably restrictive within its remit, but its remit is also narrow, making it virtually invisible in terms of achieving actual reductions in small arms trafficking. This is because relevant offences against the Firearms Protocol must be "transnational in nature and involve an organised criminal group". ${ }^{96}$ Nor does the Firearms Protocol apply to any transfers between states, or where the transfer would affect the ability of Party States to ensure their "national security". ${ }^{97}$ The limits of the Firearms Protocol are made quite clear in several cases where the actions would have breached the Firearms Protocol if they involved an organised criminal group or if the states involved were Party States. These include the cases against arms dealers Monzer al Kassar, Leonid Minin, Vladimir Montesinos and Viktor Bout. ${ }^{98}$ The Firearms Protocol does however show that there is an emerging shift in how international law regards small arms and light weapons. It also provides proof that there is a normative change towards seeing these weapons as a 'problem', and follows 'framing' theories,

${ }^{94}$ United Nations General Assembly, Protocol against the Illicit Manufacturing of and Trafficking in Firearms, Their Parts and Components and Ammunition, supplementing the United Nations. The Firearms Protocol came into effect in 2005, after the requisite number of states ratified it.

${ }^{95}$ Ibid. Articles 5 and 8.

${ }^{96}$ Ibid. Article 4.

${ }^{97}$ Ibid. Article 4.

${ }^{98}$ Amnesty International, Deadly Movements: Arms Transportation Controls in the Arms Trade Treaty; Amnesty International, "Italian Courts Release Arms Dealer"; United States of America v. Viktor Bout, a/k/a "Boris," : a/k/a "Victor Anatoliyevich Bout," : a/k/a "Victor But," : a/k/a "Viktor Budd," : a/k/a "Viktor Butt," : a/k/a "Viktor Bulakin," : a/k/a "Vadim Markovich Aminov, ” and Andrew Smulian, : Defendants. United States of America : Sealed Complaint: Violations of Title 18, United States Code, Sections $2339 B$ \& 3238. 
as the Firearms Protocol was created after the precedent of the AP landmine ban (1997) previously mentioned..$^{99}$

\section{The Programme of Action}

The United Nations Programme of Action on the Illicit Trade in Small Arms and Light Weapons in All Its Aspects was the precursor to the Arms Trade Treaty. Unlike the Treaty, it is a politically binding instrument which was created in 2001, at the conclusion of the United Nations Conference on small arms issues in New York. ${ }^{100}$ The Programme of Action specifically refers to the damage done by the illicit arms trade in its preamble and the way that it "exacerbates violence, contributes to the displacement of civilians, undermines respect for international humanitarian law, impedes the provision of humanitarian assistance to victims of armed conflict and fuels crime and terrorism". ${ }^{101}$ The Programme of Action requires states to make an effort at the national level to prevent and reduce the illicit transfer of small arms through a number of actions such as establishing effective export control and licensing systems, recording and reporting transfers and ensuring that manufacturers are licensed. ${ }^{102}$ Further to this, regional and international cooperation and actions are also recommended to prevent international illicit transfers of these weapons. ${ }^{103}$ The document, while only politically binding, is the most comprehensive international treatment of the issue of the transfer of SALW. It has therefore contributed extensively to the development of norms associated with these weapons

\footnotetext{
${ }^{99}$ Nadelmann, "Global Prohibition Regimes: the Evolution of Norms in International Society," 485; Payne, "Persuasion, Frames and Norm Construction"; Snow et al., "Frame Alignment Processes, Micromobilization, and Movement Participation."

${ }^{100}$ United Nations Department for Disarmament Affairs, "Programme of Action to Prevent, Combat and Eradicate the Illicit Trade in Small Arms and Light Weapons in All Its Aspects." Hereafter referred to as the Programme of Action Conference.

${ }^{101}$ Ibid.

${ }^{102}$ Ibid., 2-23.

${ }^{103}$ Ibid., 24-41.
} 
such as brokering, marking and tracing, and the destruction of weapons surplus to requirements.

\section{Specific regional agreements}

Soon after the 1995 Resolution 50/70 and the Panel of Experts Report which was actioned by that resolution, Latin America took action to address the problem of illicit SALW. The Organisation of American States (OAS) established the InterAmerican Convention Against the Illicit Manufacturing of and Trafficking in Firearms, Ammunition, Explosives and Related Materials in 1997 after agreeing that these weapons posed a threat to both national and regional security. ${ }^{104}$ The InterAmerican Convention was a legally binding instrument and became a point of reference for other international tools created to tackle the proliferation of small arms and its effects. ${ }^{105}$ In addition, there have been a number of other measures taken in the greater Latin American region such the Inter-American Drug Abuse Control Commission's Model Regulations for the Control of the International Movement of Firearms, their Parts and Components and Ammunition. ${ }^{106}$

Other regions have since followed suit, developing their own legislative and regulatory mechanisms to 'prevent, combat and eradicate' illicit small arms trading. In Africa, the South African Development Community (SADC), the Economic

\footnotetext{
${ }^{104}$ Organisation of American States, Inter-American Convention against the Illicit Manufacturing of and Trafficking in Firearms, Ammunition, Explosives, and Other Related Materials. Hereafter this instrument will be referred to as the Inter-American Convention and the Organisation of American States by its acronym OAS. Note: The United States is a member, but has not ratified this Convention.

${ }^{105}$ Garcia, Small Arms and Security: New Emerging International Norms, 53.

${ }^{106}$ Andean Community, Decision 552: Andean Plan to Prevent, Combat and Eradicate Illicit Trade in Small Arms and Light Weapons in all its Aspects (and Annexes); Nicaragua, "Working Paper Submitted by Nicaragua: Code of Conduct of Central American States on the Transfer of Arms, Ammunition, Explosives and Other Related Materiel (A/CONF.192/2006/RC/WP.6)"; InterAmerican Drug Abuse Control Commission, Model Regulations for the Control of the International Movement of Firearms, their Parts And Components and Ammunition - Updated. The Code of Conduct referred to in the Nicaraguan submission will be referred to as the Central American Code of Conduct.
} 
Community of West African States (ECOWAS), and the Great Lakes Region and Horn of Africa have all established mechanisms to control the transfer of weapons. ${ }^{107}$ The SADC created the Protocol on the Control of Firearms, Ammunition and Other Related Materials in the Southern African Development Community (SADC) Region in $2001^{108}$, which requires member states to take a number of actions such as preventing "unrestricted possession of small arms by civilians" and marking and tracing of these weapons was undertaken. ${ }^{109}$ Likewise, the Great Lakes Region and Horn of Africa grouping instigated the Nairobi Protocol for the Prevention, Control and Reduction of Small Arms and Light Weapons in the Great Lakes Region and the Horn of Africa in 2004. ${ }^{110}$ ECOWAS was a trailblazer in the area of SALW controls, as they instituted a three year moratorium on light weapons as far back as 1998, which has been continued since that time. ${ }^{111}$ Later they addressed the issue of SALW with the 2006 ECOWAS Convention, which dealt with small arms by establishing a system whereby no transfers were allowed unless specifically granted an exemption. 112

In Europe, both the European Union (EU) and the Organisation for Security and Cooperation in Europe (OSCE) have addressed the issue of small arms

\footnotetext{
${ }^{107}$ Hereafter the Southern Africa Development Community and the Economic Community of West Africa States will be referred to by their respective acronyms SADC and ECOWAS.

${ }^{108}$ Southern African Development Community, Protocol on the Control of Firearms, Ammunition and Other Related Materials in the Southern African Development Community (SADC) Region. Hereafter this instrument will be referred to as the SADC Protocol.

${ }^{109}$ Ibid.

${ }^{110}$ Republic of Burundi et al., The Nairobi Protocol for the Prevention, Control and Reduction of Small Arms and Light Weapons in the Great Lakes Region and the Horn of Africa. Hereafter this instrument will be referred to as the Nairobi Protocol.

${ }^{111}$ Economic Community of West African States (ECOWAS), Declaration of a Moratorium on Importation, Exportation and Manufacture of Light Weapons in West Africa. Hereafter this instrument will be referred to as the ECOWAS Moratorium.

${ }^{112}$ Economic Community of West African States (ECOWAS), ECOWAS Convention on Small Arms and Light Weapons, Their Ammunition and Other Related Materials. Hereafter this instrument will be referred to as the ECOWAS Convention.
} 
proliferation recently, through a series of Codes of Conduct, Handbooks and Joint Actions. ${ }^{113}$ The Pacific region created the Nadi Framework to begin work on preventing the proliferation of small arms and light weapons. ${ }^{114}$ Similarly, the League of Arab States has a 2002 Model Law on Weapons, Ammunitions, Explosives and Hazardous Material and later continued to undertake a series of resolutions on the issue. ${ }^{115}$ From this array of regional legislative and regulatory instruments, it is possible to see a recent trend which suggests increasing acceptance of small arms norms.

\section{The Arms Trade Treaty}

The Arms Trade Treaty is a proposed international law, combining a number of small arms control norms into one mechanism which is legally binding on Party States. It draws on the variety of instruments already in place, to create a global standard for all conventional arms trading between states. The Treaty was first considered in 2006, when Resolution 61/89 established a Group of Governmental

\footnotetext{
${ }^{113}$ Council of the European Union, European Code of Conduct on Arms Exports; Council of the European Union, Council Joint Action of 12 July 2002 on the European Union's Contribution to Combating the Destabilising Accumulation and Spread of Small Arms and Light Weapons and Repealing Joint Action 1999/34/; Council of the European Union, EU Strategy to Combat Illicit Accumulation and Trafficking of SALW and Their Ammunition; Organisation for Security and Cooperation in Europe (OSCE), OSCE Document on Small Arms and Light Weapons; Organisation for Security and Cooperation in Europe (OSCE), "OSCE Handbook of Best Practices on Small Arms and Light Weapons. Decision No. 5/03 Best Practice Guides on Small Arms and Light Weapons." Hereafter the EU Code of Conduct on Arms Exports will be referred to as the EU Code of Conduct, the Council Joint Action of 12 July 2002 will be referred to as the EU Council Joint Action, and the EU Strategy to Combat Illicit Accumulation and Trafficking of SALW will be referred to as the EU Strategy Document. The OSCE Handbook of Best Practices on Small Arms and Light Weapons will be referred to as the OSCE Handbook of Best Practices and the OSCE Document on Small Arms and Light Weapons will be referred to as the OSCE Document.

${ }^{114}$ South Pacific Chiefs of Police Conference (SPCPC) Working Group and Pacific Islands Forum, "Nadi Framework: Legal Framework for a Common Approach to Weapons Control." Hereafter this instrument will be referred to as the Nadi Framework.

${ }^{115}$ League of Arab States - Ministerial Council, Resolution 6447 on Arab Coordination for Combating the Illicit Trade in Small Arms and Light Weapons; League of Arab States - Ministerial Council, Resolution 6625 on Arab Coordination for Combating the Illicit Trade in Small Arms and Light Weapons; Interior Ministers Council League of Arab States (General Secretariat), Arab Model Law on Weapons, Ammunitions, Explosives and Hazardous Material. Hereafter the Arab Model Law on Weapons, Ammunitions, Explosives and Hazardous Material will be referred to as the Arab Model Law.
} 
Experts on the arms trade ${ }^{116}$, before a draft resolution to work towards an Arms Trade Treaty was proposed by like-minded states and accepted in 2009 by the United Nations ${ }^{117}$. Many NGOs in the human security area welcomed this development, having worked on protecting human rights and life against armed violence for years, however pro-gun NGOs view this occurrence as alarming. The response from states has been mixed, as they recognise the wide array of policies and practices that this instrument will affect.

The cluster of norms being considered for inclusion into an international law, regulating the trade in small arms and light weapons and other conventional weapons, has been established over a period of time. Each is based on the promotion, diffusion and institutionalisation of it into international society, however not all of them are equally accepted or institutionalised, in fact some have been considered to have failed. Nevertheless, these norms continue to be associated with the ATT and its promotion. This indicates that a closer look at these norms is needed to ascertain their position in relation to the Arms Trade Treaty and its future acceptance.

\section{The Arms Trade Treaty norm cluster}

There are seven major norms in the Arms Trade Treaty cluster, and several other less dominant associated norms. The seven primary norms are 1) brokering, 2) civilian possession, 3) destruction and disposal of surplus stock, 4) international human rights law and international humanitarian law, 5) marking and tracing, 6) preventing non-state actor acquisition, and 7) transparency. This thesis focuses on just three of these - brokering, civilian ownership and non-state actor acquisition -

\footnotetext{
${ }^{116}$ United Nations General Assembly, Towards an Arms Trade Treaty: Establishing Common International Standards for the Import, Export and Transfer of Conventional Arms.

${ }^{117}$ Argentina et al., The Arms Trade Treaty (revised draft resolution), United Nations General Assembly.
} 
and these were chosen because they represent points of confluence or conflict and thus arguably have the power to shape the final outcome of the Treaty. However all seven of these dominant norms are strongly associated with the Arms Trade Treaty and its ultimate purpose of controlling conventional weapons, including SALW. The cluster of norms which relate to the Arms Trade Treaty all seek to ameliorate the proliferation of SALW, and the effects that this proliferation has. At the first PrepCom, Canada, Egypt, France and Japan specifically referred to creating a 'normative' framework or Treaty, for the purpose of controlling small arms. ${ }^{118}$ The four primary norms not studied here include one of the most well-known and accepted norms in the control of small arms: the destruction and disposal of surplus weapons. Garcia argues that this norm was developed in three stages, related to the emergence of post-conflict peace-keeping, the effects of the dispersion of excessive state arsenals after the Cold War and finally the numbers of confiscated weapons related to crimes. ${ }^{119}$ The removal of weapons from tense post-conflict situations is a positive step towards building trust between the previously conflicting parties, and their destruction prevents them finding their way to another conflict. This norm emerged in 2003 as states included disarmament and destruction efforts when they reported to the UN on their implementation of the Programme of Action. ${ }^{120}$ A second UNIDIR report indicated even more states were making efforts in the field of disarmament and disposal of small arms, strengthening the norm further, and DDR

\footnotetext{
${ }^{118}$ Notes taken by author at the Preparatory Committee for the United Nations Conference on the Arms Trade Treaty, New York, July 12-23 2010. [Hereafter these will be referred to as 'Author's notes from PrepCom Day X, y session'.]

${ }^{119}$ Garcia, Small Arms and Security: New Emerging International Norms, 66-68.

${ }^{120}$ Ibid., 69; Kytömäki and Yankey-Wayne, Implementing the United Nations Programme of Action on Small Arms and Light Weapons: Analysis of Reports Submitted by States in 2003.
} 
has now become an accepted practice. ${ }^{121122}$ Statements made at the first PrepCom on the Arms Trade Treaty include references to destruction and disposal of surplus weapons, both in post-conflict situations and in terms of preventing destabilising accumulation of weapons in any state. ${ }^{123}$ Thus we can say that the norm has both emerged and been institutionalised to some degree into states' thinking about and practice related to SALW. ${ }^{124}$

Another leading small arms norm is the requirement for marking of weapons. ${ }^{125}$ As was briefly alluded to above, weapons and ammunition are marked upon manufacture or import, in order to trace their path from manufacture to end use. ${ }^{126}$ The purpose of this is threefold: first it assists in the recordkeeping related to these weapons and their ammunition; second it assists in tracing these items in the case of their illegal manufacture/modification, transfer or use (and possible prosecution of such actions at either national or international level), and third, these two practices enable confidence-building and transparency in the sector. This

\footnotetext{
${ }^{121}$ Kytömäki and Yankey-Wayne, Five Years of Implementing the United Nations Programme of Action on Small Arms and Light Weapons: Regional Analysis of National Reports.

${ }^{122}$ See for example Wassenaar Arrangement Secretariat, The Wassenaar Arrangement on Export Controls for Conventional Arms and Dual-Use Goods and Technologies. Basic Documents; Biting the Bullet Project, Reviewing Action on Small Arms 2006: Assessing the First Five Years of the UN Programme of Action; Organisation for Security and Cooperation in Europe (OSCE), OSCE Document on Small Arms and Light Weapons; Parker, National Implementation of the United Nations Small Arms Programme of Action and the International Tracing Instrument: An Analysis of Reporting in 2009-10 (Interim Version, June 2010); Parker and Cattaneo, Implementing the United Nations Programme of Action on Small Arms and Light Weapons: Analysis of the National Reports Submitted by States from 2002 to 2008 (Draft Report).

${ }^{123}$ Author's notes from PrepCom Day 2, morning session; Author's notes from PrepCom Day 5, morning session; United Nations General Assembly, The Arms Trade Treaty; Moritán, "Chairman's Draft Paper - 22 July 2010"; Quinlan, "Facilitator's Summary on Parameters."

${ }^{124}$ Rare mentions of the norm could indicate that the norm is failing to maintain prominence but could also indicate that it is completely accepted as a norm to be associated with the Treaty.

${ }^{125}$ Marking and tracing is rendered moot without comprehensive and consistent recording of the markings and transfers of these items, which reinforces transparency.

${ }^{126}$ While ammunition is included here, there are fewer normative or legal requirements which result in this practice being undertaken. Control Arms Campaign, Tracking Lethal Tools. Marking and Tracing Arms and Ammunition: A Central Piece of the Arms Control Puzzle.
} 
concept was first put forward in the Inter-American Convention ${ }^{127}$, and subsequently included in the Programme of Action in the form of a requirement for states to ensure that manufacturers marked weapons at the time of production. ${ }^{128}$ In addition to the emergence of the International Instrument to Enable States to Identify and Trace, in a Timely and Reliable Manner, Illicit Small Arms and Light Weapons in 2005 as a specific tool to address the issue ${ }^{129}$, the norm is clearly becoming stronger as it has been included in the Firearms Protocol and various international and regional instruments. ${ }^{130}$ It was also mentioned in the first PrepCom by a number of states and in the draft outcome documents. ${ }^{131}$

Related to this norm, and to more general norms of good faith interactions between states, is the norm of transparency in the area of small arms and light

\footnotetext{
${ }^{127}$ Organisation of American States, Inter-American Convention against the Illicit Manufacturing of and Trafficking in Firearms, Ammunition, Explosives, and Other Related Materials. Article VI.

${ }^{128}$ United Nations Department for Disarmament Affairs, "Programme of Action to Prevent, Combat and Eradicate the Illicit Trade in Small Arms and Light Weapons in All Its Aspects." Section II, Para. 7.

${ }^{129}$ United Nations General Assembly, International Instrument to Enable States to Identify and Trace, in a Timely and Reliable Manner, Illicit Small Arms and Light Weapons. Hereafter this instrument will be referred to as the International Tracing Instrument.

${ }^{130}$ See for example Council of the European Union, EU Strategy to Combat Illicit Accumulation and Trafficking of SALW and Their Ammunition; Inter-American Drug Abuse Control Commission, Model Regulations for the Control of the International Movement of Firearms, their Parts And Components and Ammunition - Updated; Organisation for Security and Cooperation in Europe (OSCE), OSCE Document on Small Arms and Light Weapons; Republic of Burundi et al., The Nairobi Protocol for the Prevention, Control and Reduction of Small Arms and Light Weapons in the Great Lakes Region and the Horn of Africa; United Nations Department for Disarmament Affairs and The League of Arab States Department for Disarmament, "Co-Chair's Summary. Implementation, by the Arab States, of the United Nations Programme of Action on the Illicit Trade in Small Arms and Light Weapons"; United Nations General Assembly, Protocol against the Illicit Manufacturing of and Trafficking in Firearms, Their Parts and Components and Ammunition, supplementing the United Nations; Wassenaar Arrangement Secretariat, The Wassenaar Arrangement on Export Controls for Conventional Arms and Dual-Use Goods and Technologies. Basic Documents; United Nations General Assembly, General and Complete Disarmament: The Illicit Trade in Small Arms and Light Weapons in all its Aspects.
}

${ }^{131}$ Author's notes from PrepCom Day 2, morning session; Author's notes from PrepCom Day2, afternoon session; Author's notes from PrepCom Day 3, afternoon session; Author's notes from PrepCom Day 4, morning session; Author's notes from PrepCom Day 5, morning session; Aly, "Facilitator's Summary on Implementation and Application.". The concept is also referred to implicitly as part of transparency measures and ensuring the "ability to control the movement of arms". Moritán, “Chairman's Draft Paper - 22 July 2010”; Quinlan, "Facilitator's Summary on Parameters." 
weapons control. Marking and tracing is undertaken by states to contribute to transparency in the trade and more general confidence-building. These markings are recorded and used in any investigation of criminal activity, but they can also give a more accurate picture of stockpiles for destruction and preventing "destabilising accumulations" of weapons. ${ }^{132}$ Obviously, releasing detailed information about state stocks - or armed group stocks for that matter - is not something that is common practice. National security is a notoriously opaque area of government, and states' defence force and law enforcement officials are unlikely to support such transparency measures without some form of compulsion, therefore it may be surprising to note that this norm is developing in relation to the Arms Trade Treaty. Garcia credits its development to a pioneering study done by the United Nations in the early 1990s on "ways and means of promoting transparency" of armaments and the role of the United States in promoting democracy. ${ }^{133}$ In the years after this, the United Nations continued to refer to notions of transparency in relation to arms transfers and controls, including in several instruments on arms transfers and in resolutions on the feasibility of an ATT. ${ }^{134}$ Other international and regional

\footnotetext{
${ }^{132}$ Wassenaar Arrangement Secretariat, The Wassenaar Arrangement on Export Controls for Conventional Arms and Dual-Use Goods and Technologies. Basic Documents; Greene, "Examining International Responses to Illicit Arms Trafficking," 155; Greene and Kirkham, Preventing Diversion of Small Arms and Light Weapons: Issues and Priorities for Strengthened Controls, 18; Cornish, Arms Trade Treaty - Building Consensus and Making it Work, 17.

${ }^{133}$ Garcia, Small Arms and Security: New Emerging International Norms; United Nations General Assembly, Study on Ways and Means of Promoting Transparency in International Transfers of Conventional Arms.

${ }^{134}$ Argentina et al., The Arms Trade Treaty (revised draft resolution); United Nations Department for Disarmament Affairs, "Programme of Action to Prevent, Combat and Eradicate the Illicit Trade in Small Arms and Light Weapons in All Its Aspects"; United Nations General Assembly, General and Complete Disarmament: Consolidation of Peace through Practical Disarmament Measures, United Nations General Assembly; United Nations General Assembly, General and Complete Disarmament: Transparency in Armaments; United Nations General Assembly, Information on Confidence-Building Measures in the Field of Conventional Arms; United Nations General Assembly, Report of the Disarmament Commission (Guidelines for International Arms Transfers in the Context of General Assembly Resolution 46/36 H of 6 December 1991); United Nations General Assembly, Report of the Group of Governmental Experts Established Pursuant to General Assembly Resolution 60/81 to Consider Further Steps to Enhance International Cooperation in Preventing, Combating and Eradicating Illicit Brokering in Small Arms and Light Weapons, United Nations General Assembly;
} 
instruments also referred to transparency. ${ }^{135}$ Numerous statements at the PrepCom referred to the importance of conducting negotiations in a transparent manner and to including measures to ensure that transparency is included in an ATT, in relation to reporting on transfers and activities. ${ }^{136}$ This suggests that the norm of transparency is in fact quite strong in relation to the Arms Trade Treaty.

The inclusion of International Human Rights Law (IHRL) and International Humanitarian Law (IHL) into arms controls is not a new consideration, but it has proved problematic in practical terms. Specific references to IHL and/or IHRL have been included in the Programme of Action, the Wassenaar Arrangement, the Andean Plan, the Nairobi Protocol, the Central American Code of Conduct, the EU Strategy Document, OSCE Document and the ECOWAS Convention. However an equivalent number of arms international and regional instruments make no reference to humanitarian or human rights concerns, which cut across regions which have also

United Nations General Assembly, Towards an Arms Trade Treaty: Establishing Common International Standards for the Import, Export and Transfer of Conventional Arms.; United Nations General Assembly, Towards an Arms Trade Treaty: Establishing Common International Standards for the Import, Export and Transfer of Conventional Weapons.

${ }^{135}$ Andean Community, Decision 552: Andean Plan to Prevent, Combat and Eradicate Illicit Trade in Small Arms and Light Weapons in all its Aspects (and Annexes); Council of the European Union, European Code of Conduct on Arms Exports; Council of the European Union, Council Joint Action of 12 July 2002 on the European Union's Contribution to Combating the Destabilising Accumulation and Spread of Small Arms and Light Weapons and Repealing Joint Action 1999/34/; Council of the European Union, EU Strategy to Combat Illicit Accumulation and Trafficking of SALW and Their Ammunition; Economic Community of West African States (ECOWAS), ECOWAS Convention on Small Arms and Light Weapons, Their Ammunition and Other Related Materials; Organisation for Security and Cooperation in Europe (OSCE), OSCE Document on Small Arms and Light Weapons; Republic of Burundi et al., The Nairobi Protocol for the Prevention, Control and Reduction of Small Arms and Light Weapons in the Great Lakes Region and the Horn of Africa; United Nations Department for Disarmament Affairs and The League of Arab States Department for Disarmament, "Co-Chair's Summary. Implementation, by the Arab States, of the United Nations Programme of Action on the Illicit Trade in Small Arms and Light Weapons."

${ }^{136}$ Author's notes from PrepCom Day 1, morning session; Author's notes from PrepCom Day 1, afternoon session; Author's notes from PrepCom Day 2, morning session; Author's notes from PrepCom Day 2, afternoon session; Author's notes from PrepCom Day 3, morning session; Author's notes from PrepCom Day 3, afternoon session; Author's notes from PrepCom Day 4, morning session; Aly, "Facilitator's Summary on Implementation and Application"; Moritán, "Chairman's Draft Elements"; Moritán, “Chairman’s Draft Paper - 22 July 2010”; Moritán, “Chairman’s Draft Principles"; Quinlan, "Facilitator's Summary on Parameters." 
recognised the notion. ${ }^{137}$ Morocco and the United Kingdom referred to upholding humanitarian law as the 'raison d'être' of the ATT at the PrepCom. ${ }^{138}$ Many states referred to IHRL and IHL in their early submissions on the Programme of Action; however analysis of their later submissions shows fewer references. ${ }^{139}$ The resolution which established the negotiations on the Arms Trade Treaty alludes to both IHRL and IHL, and the need for states to respect such principles, as do previous resolutions on the development of the ATT. ${ }^{140}$ Despite this, there is no consensus about whether

${ }^{137}$ Inter-American Drug Abuse Control Commission, Model Regulations for the Control of the International Movement of Firearms, their Parts And Components and Ammunition - Updated; Interior Ministers Council League of Arab States (General Secretariat), Arab Model Law on Weapons, Ammunitions, Explosives and Hazardous Material; League of Arab States - Ministerial Council, Resolution 6447 on Arab Coordination for Combating the Illicit Trade in Small Arms and Light Weapons; League of Arab States - Ministerial Council, Resolution 6625 on Arab Coordination for Combating the Illicit Trade in Small Arms and Light Weapons; South Pacific Chiefs of Police Conference (SPCPC) Working Group and Pacific Islands Forum, "Nadi Framework: Legal Framework for a Common Approach to Weapons Control"; Southern African Development Community, Protocol on the Control of Firearms, Ammunition and Other Related Materials in the Southern African Development Community (SADC) Region; United Nations General Assembly, General and Complete Disarmament: Transparency in Armaments; United Nations General Assembly, Protocol against the Illicit Manufacturing of and Trafficking in Firearms, Their Parts and Components and Ammunition, supplementing the United Nations.

${ }^{138}$ Author's notes from PrepCom Day 2, afternoon session; Author's notes from PrepCom Day 3, morning session; Chabi, "Statement of the Kingdom of Morocco on the Principles of a Future ATT, by M. Amine Chabi, First Counsellor, Prepcom of the ATT"; Duncan, "Statement by Ambassador John Duncan, UK Ambassador for Multilateral Arms Control Disarmament, on Principles of an Arms Trade Treaty."

${ }^{139}$ Biting the Bullet Project, Reviewing Action on Small Arms 2006: Assessing the First Five Years of the UN Programme of Action; Kytömäki and Yankey-Wayne, Implementing the United Nations Programme of Action on Small Arms and Light Weapons: Analysis of Reports Submitted by States in 2003; Parker, National Implementation of the United Nations Small Arms Programme of Action and the International Tracing Instrument: An Analysis of Reporting in 2009-10 (Interim Version, June 2010); Parker and Cattaneo, Implementing the United Nations Programme of Action on Small Arms and Light Weapons: Analysis of the National Reports Submitted by States from 2002 to 2008 (Draft Report).

${ }^{140}$ Argentina et al., The Arms Trade Treaty (revised draft resolution); United Nations Department for Disarmament Affairs, "Programme of Action to Prevent, Combat and Eradicate the Illicit Trade in Small Arms and Light Weapons in All Its Aspects"; United Nations General Assembly, Report of the Disarmament Commission (Guidelines for International Arms Transfers in the Context of General Assembly Resolution 46/36 H of 6 December 1991); United Nations General Assembly, Report of the Group of Governmental Experts to Examine the Feasibility, Scope and Draft Parameters for a Comprehensive, Legally Binding Instrument Establishing Common International Standards for the Import, Export and Transfer of Conventional Arms, United Nations General Assembly; United Nations General Assembly, Towards an Arms Trade Treaty: Establishing Common International Standards for the Import, Export and Transfer of Conventional Arms.; United Nations General Assembly, Towards an Arms Trade Treaty: Establishing Common International Standards for the Import, Export and Transfer of Conventional Weapons. Note: the Programme of Action only refers to IHL. 
or not to include such references in the Arms Trade Treaty, with several states expressing concern about the inclusion of such "subjective" criteria for evaluating arms transfer decisions. ${ }^{141}$ These are indeed subjective criteria with which to guide decision-making about arms imports, exports and transfers of all forms, but this may not be as problematic as they are painted. There are instances where independent, authoritative sources are able to verify such occurrences and these could act as a baseline for such decisions, in a similar way to that which the United Nations uses to make decisions about the imposition of arms embargoes on nations in conflict.

In addition to these core norms (and the three that follow in the next chapters) there are several other, less prominent norms related to the Arms Trade Treaty, being: prevention of diversion, ammunition, victim assistance, assistance to implement the Treaty, organised crime/terrorism, dual use components, restricted production, and associated technology. Ambassador Moritán commented on his draft 'non-paper' on elements to clarify that some ideas were not listed specifically as they would naturally flow from other elements listed, or might be addressed in another area of discussion, noting prevention of diversion as one such norm. ${ }^{142}$ Victim assistance was championed by NGOs and rarely mentioned by most states. ${ }^{143}$ Ammunition was a contentious issue in all contexts it was referred to, but several states defended the inclusion of it, albeit some within the remit of the ' $7+1+1$ '

\footnotetext{
${ }^{141}$ Author's notes from PrepCom Day 2, morning session; Author's notes from PrepCom Day 2, afternoon session; Author's notes from PrepCom Day 3, morning session; Author's notes from PrepCom Day 5, morning session.

${ }^{142}$ Author's notes from PrepCom Day 3, morning session; Moritán, "Chairman's Draft Elements." Moritán also listed organised crime, terrorism and corruption as such notions, and stated that some ideas were left out because he felt unsure about where they fit, including victim assistance.

${ }^{143}$ Author's notes from PrepCom Day 1, afternoon session; Author's notes from PrepCom Day 2, morning session; Author's notes from PrepCom Day 3, morning session; Author's notes from PrepCom Day 3, afternoon session; Author's notes form PrepCom Day 4, morning session.
} 
formulation. ${ }^{144}$ Dual-use goods and technologies were equally divisive concepts during the discussions, with no clear consensus on their inclusion or exclusion. ${ }^{145}$

\section{Conclusion}

The Arms Trade Treaty norm cluster has emerged from a series of earlier normative developments. It represents the culmination of years of norm promotion and education by states and NGOs, to having become more or less acceptable standards of behaviour for arms transfers and therefore obvious source material for the ATT. As shown above, the elaboration of the cluster of norms in the Arms Trade Treaty has been foreshadowed by the development of other security norms, namely those related to AP landmines and cluster munitions. The divergent progress of the paths of these norms in the security field left open the ability to predict the course of the ATT norm cluster. In combination with the wide remit of the negotiations at this point, it becomes important to consider the path of the most prominent norms within the cluster to determine the future of the Treaty, and it is to this task that the next chapters turn.

\footnotetext{
${ }^{144}$ Author's notes from PrepCom Day 1, afternoon session; Author's notes from PrepCom Day 2, morning session; Author's notes from PrepCom Day 2, afternoon session; Author's notes from PrepCom Day 3, morning session; Author's notes from PrepCom Day 3, afternoon session; Author's notes from PrepCom Day 4, morning session; Author's notes from PrepCom Day 5, morning session. $7+1+1$ makes reference to the scope of the ATT being simply taken as the 7 categories of the UN ROCA, plus SALW, plus ammunition. While a popular categorisation among states, it is dismissed by NGOs as 'minimalist'. Amnesty International, Blood at the Crossroads: Making the Case for a Global Arms Trade Treaty.

${ }^{145}$ Author's notes form PrepCom Day 2, morning session; Author's notes from PrepCom Day 5, morning session; Youngman, "Statement by the Defense Small Arms Advisory Council (DSAAC)."
} 


\section{Chapter Four - Brokering and the Arms Trade Treaty}

\section{Introduction}

In this chapter, the focus is on how the norm regulating brokering developed in relation to small arms and the Arms Trade Treaty. It begins by explaining what brokering is and what the norm is, before undertaking an analysis of the development of the regulation of brokering norm in the ATT context.

\section{What is brokering?}

An arms broker is generally considered to be an actor who facilitates a transaction in which small arms are traded. ${ }^{146}$ The Group of Experts Report of 2007 describes a broker as

a person or entity acting as an intermediary that brings together relevant parties and arranges or facilitates a potential transaction of small arms and light weapons in return for some form of benefit, whether financial or otherwise. ${ }^{147}$

Any actions which a broker undertakes can be either legal or illegal, depending upon whether the correct authorisation has been granted and the goods have been appropriately transported according to the manifesto and any potential safety considerations. In the case of weapons, most actors involved are state officials and manufacturers in the defence sector, and therefore the requisite authorisations and considerations are undertaken as a matter of course. ${ }^{148}$

\footnotetext{
${ }^{146}$ Brokering is not an activity restricted to the field of arms transfers.

${ }^{147}$ United Nations General Assembly, Report of the Group of Governmental Experts Established Pursuant to General Assembly Resolution 60/81 to Consider Further Steps to Enhance International Cooperation in Preventing, Combating and Eradicating Illicit Brokering in Small Arms and Light Weapons. Hereafter referred to as the Experts Report on Brokering.

${ }^{148}$ Many civil society organisations and some states are pushing for the inclusion of human rights law and international humanitarian law into arms trade decision-making by states. See Moritán, “Chairman's Draft Paper - 22 July 2010"; International Committee of the Red Cross, Arms Transfer Decisions: Applying International Humanitarian Law. Practical Guide.
} 
The common practice of brokering in small arms and light weapons can be described thus: Person A wants to purchase small arms but may not know Person B, who has these weapons to trade. ${ }^{149}$ Person C, a.k.a. the broker, may do nothing more than introduce the persons involved and be paid for doing so, or they may be more involved such as in transporting the goods to their destination or handling the purchase of the goods. The weapons then go on to fuel conflicts, contribute to crimes or violate human rights. The Experts Report on Brokering itemises potential brokering activities as "technical assistance, training, transport, freight forwarding, storage, finance, insurance, maintenance, security", showing a range of potential brokering activities. ${ }^{150}$ The exploits of such infamous figures as Victor Bout, Leonid Minin, and Jean Bernard Lasnaud showcase the illicit activities that brokers engage in. ${ }^{151}$ They are known to purchase weapons with false identification and licences, then transport the weapons without the correct authorisation, using fake travel and export documents where necessary. Officials are bribed to overlook any discrepancies and identifying features on transportation are altered at will to evade discovery. ${ }^{152}$ The Experts Report on Brokering stated that

\footnotetext{
${ }^{149}$ Person A can be an individual, but can also be a company, organisation or other legal entity. Likewise for Person B, although most brokers (Person C) tend to operate as individuals or in very small groups, within a greater network involving all aspects of (illicit) transactions and transportation. ${ }^{150}$ United Nations General Assembly, Report of the Group of Governmental Experts Established Pursuant to General Assembly Resolution 60/81 to Consider Further Steps to Enhance International Cooperation in Preventing, Combating and Eradicating Illicit Brokering in Small Arms and Light Weapons.

${ }^{151}$ Amnesty International, "Italian Courts Release Arms Dealer"; Brunwasser, "Gunrunners: Gallery of International Arms Dealers - Leonid Efimovich Minin"; Brunwasser, "Gunrunners: Gallery of International Arms Dealers - Victor Anatoleyevich Bout"; Reynolds, Kistner, and Lavieri, "Gunrunners: Gallery of International Arms Dealers - Jean Bernard Lasnaud."

${ }^{152}$ Amnesty International, Dead on Time - Arms Transportation, Brokering and the Threat to Human Rights; Amnesty International, Deadly Movements: Arms Transportation Controls in the Arms Trade Treaty; United Nations General Assembly, Report of the Group of Governmental Experts Established Pursuant to General Assembly Resolution 60/81 to Consider Further Steps to Enhance International Cooperation in Preventing, Combating and Eradicating Illicit Brokering in Small Arms and Light Weapons.
} 
Analyses of such activities revealed that illicit brokers typically conduct their business by exploiting legal loopholes, evading customs and airport controls, and falsifying documents such as passports, end-user certificates and cargo papers. ${ }^{153}$

These arms brokers have been able evade prosecution in relation to illicit arms transfers for some time, owing to loopholes in jurisdiction and legislation.

Several brokering cases have been tried throughout the world, and while many of them were tried domestically, each had international aspects. The United States tried Monzer al Kassar, Tareq Mousa al Ghazi and Luis Felipe Moreno Godoy in 2007, after it was alleged that they sold weapons to a terrorist organisation, Fuerzas Armadas Revolucionarias de Colombia (FARC) ${ }^{154}$ In 2008, Russian resident Victor Bout was arrested and extradited to the US to face charges of illicit arms brokering in violation of its anti-terrorism law, also for supplying weapons to FARC, and is currently facing a court trial. ${ }^{155}$ It is believed that the US is attempting to use these cases to find out more about the arms trafficking process, rather than target Bout specifically for his dealings with FARC. ${ }^{156}$ Previously two other cases had been undertaken, in Italy for Leonid Minin who allegedly breached an arms embargo in Sierra Leone ${ }^{157}$; and in the US for Vlademiros Montesinos who is linked to several

\footnotetext{
${ }^{153}$ United Nations General Assembly, Report of the Group of Governmental Experts Established Pursuant to General Assembly Resolution 60/81 to Consider Further Steps to Enhance International Cooperation in Preventing, Combating and Eradicating Illicit Brokering in Small Arms and Light Weapons, 7.

${ }^{154}$ Brunwasser, "Gunrunners: Gallery of International Arms Dealers - Monzer al Kassar”; United States of America v. Monzer al-Kassar, Tareq Mousa Al Ghazi, and Luis Felipe Moreno-Godoy, Defendants.

${ }^{155}$ Brunwasser, "Gunrunners: Gallery of International Arms Dealers - Victor Anatoleyevich Bout"; United States of America v. Viktor Bout, a/k/a "Boris," : a/k/a "Victor Anatoliyevich Bout," : a/k/a "Victor But," : a/k/a "Viktor Budd," : a/k/a "Viktor Butt," : a/k/a "Viktor Bulakin," : a/k/a "Vadim Markovich Aminov," and Andrew Smulian, : Defendants. United States of America : Sealed Complaint: Violations of Title 18, United States Code, Sections $2339 B$ \& 3238.

${ }^{156}$ Horn, "Cold Case - Viktor Bout: Arms and The Man."

${ }^{157}$ Amnesty International, "Italian Courts Release Arms Dealer." The trial was unsuccessful.
} 
other arms dealers and was convicted for supplying FARC with weapons. ${ }^{158}$ These cases put pressure on states to take action against high-profile arms traffickers, despite issues with jurisdiction. The judges in the Minin court case specifically lamented the court's lack of jurisdiction, with one source reporting that

Italian judges said they found it very difficult to prosecute a man accused of illegally trafficking arms that originated and were transferred outside of Italian territory ... ${ }^{159}$

This statement goes to the heart of the issue: there is no international law which curbs the ability of brokers to facilitate weapons sales to those who should be denied access.

\section{What is the norm regulating brokering in small arms?}

The norm regulating brokering in small arms consists of three main requirements: first, that brokers of these weapons are registered or licensed in some form; second, that their actions are regulated to ensure that correct procedures are followed and can be verified; and third is a sanctioning mechanism. ${ }^{160}$ Garcia argues that the norm emerged as a result of UN Security Council Resolution 1013 (1995) which established an International Commission of Inquiry into how weapons got to

\footnotetext{
${ }^{158}$ Kistner, "Gunrunners: Gallery of International Arms Dealers - Sarkis Soghanalian.”

${ }^{159}$ Amnesty International, "Italian Courts Release Arms Dealer."

${ }^{160}$ These elements are drawn from the Programme of Action, the Experts Report on Brokering, the Firearms Protocol, the Model Convention on Brokers and the Wassenaar Arrangement's 'Best Practice Guidelines for Export of Small Arms and Light Weapons'. The Fund for Peace, "Model Convention on the Registration of Arms Brokers and the Suppression of Unlicensed Arms Brokering"; United Nations Department for Disarmament Affairs, "Programme of Action to Prevent, Combat and Eradicate the Illicit Trade in Small Arms and Light Weapons in All Its Aspects"; United Nations General Assembly, Protocol against the Illicit Manufacturing of and Trafficking in Firearms, Their Parts and Components and Ammunition, supplementing the United Nations; United Nations General Assembly, Report of the Group of Governmental Experts Established Pursuant to General Assembly Resolution 60/81 to Consider Further Steps to Enhance International Cooperation in Preventing, Combating and Eradicating Illicit Brokering in Small Arms and Light Weapons; Wassenaar Arrangement Secretariat, The Wassenaar Arrangement on Export Controls for Conventional Arms and Dual-Use Goods and Technologies. Basic Documents.
} 
Rwanda before the genocide, in breach of several UN arms embargoes. ${ }^{161}$ There were also a number of studies done by NGOs such as Amnesty International and Human Rights Watch on the situation in Rwanda up to and during the genocide. These concluded that the weapons had been transferred from a number of different states, through an intricate network of transfers, and identified that there was an absence of an international mechanism to address this issue. ${ }^{162}$ Amnesty International and Human Rights Watch acted as the primary norm entrepreneurs by instigating the international community's investigation into international arms trading, through the dissemination of these reports and continued education using their organisations' credibility to persuade others of the legitimacy of their claims. Additionally, they worked to 'name and shame' those manufacturers and countries which were found to have produced weapons which were found in Rwanda, challenging the idea that this behaviour is acceptable. ${ }^{163}$ Since that time, Oxfam has joined these organisations to promote the norm, working with the Control Arms Campaign and providing reports on brokers and their actions. ${ }^{164}$

By the end of the 1990s, a group of like-minded states and NGOs had emerged to promote the regulation of brokering, including Norway, Canada,

\footnotetext{
${ }^{161}$ Garcia, Small Arms and Security: New Emerging International Norms, 93-95; United Nations Security Council, United Nations Security Council Resolution 1013. Both UNIDIR and the Experts Report on Brokering verify that this event and the aftermath were a point of reference for the international community. Kytömäki and Yankey-Wayne, Five Years of Implementing the United Nations Programme of Action on Small Arms and Light Weapons: Regional Analysis of National Reports; United Nations General Assembly, Report of the Group of Governmental Experts Established Pursuant to General Assembly Resolution 60/81 to Consider Further Steps to Enhance International Cooperation in Preventing, Combating and Eradicating Illicit Brokering in Small Arms and Light Weapons, 7.

${ }^{162}$ Garcia, Small Arms and Security: New Emerging International Norms, 93-94; International Commission of Inquiry (Rwanda), "Final Report of the International Commission of Inquiry (Rwanda) [S/1996/1096].”

${ }^{163}$ Garcia, Small Arms and Security: New Emerging International Norms, 94.

${ }^{164}$ Cairns, "Dying for Action: Decision Time for an Urgent, Effective Arms Trade Treaty"; Control Arms Campaign, Arms Without Borders: Why a Globalised Trade Needs Global Controls; Homayun, Brokers Without Borders: How Illicit Arms Brokers can Slip Through Gaps in the Pacific and International Arms Control System.
} 
Amnesty International, Human Rights Watch and the Fund for Peace. These groups and states continued to promote action, but with little success. The most explicit reference to the subject was the United States' inclusion of brokers in its own laws ${ }^{165}$, until it was brought up in detail at the second of two Oslo meetings on small arms in 1999. ${ }^{166}$ This meeting specifically dealt with concerns about brokers being able operate in "grey zones" on the edges of the law or in places where there was no law. ${ }^{167}$ These ideas led to several publications, including the Model Convention on the Registration of Brokers and the Suppression of Unlicensed Arms Brokering, drafted for the Fund for Peace. ${ }^{168}$ This Model Convention on Brokering further developed the norm to regulate brokering and was presented to the 2001 Programme of Action Conference. Most like-minded states and interested NGOs were involved in the Oslo meetings, and in a later Ottawa meeting to prepare for the Programme of Action Conference. ${ }^{169}$ These organisations and states then went back to their constituents and continued their work on building the credibility of the norm and writing policy briefs. There were other conversations also being held around the world, such as the Bonn-Berlin Process and the Dutch-Norwegian Initiative ${ }^{170}$, and a 2005 Hollywood blockbuster Lord of War about an arms broker which brought the

\footnotetext{
${ }^{165}$ Garcia, Small Arms and Security: New Emerging International Norms, 98-99.

${ }^{166}$ Norwegian Initiative for Small Arms Trade (NISAT), “An International Agenda on Small Arms and Light Weapons: Elements of a Common Understanding"; Norwegian Initiative for Small Arms Trade (NISAT), "Elements of a Common Understanding"; United Nations General Assembly, Report of the Disarmament Commission (Guidelines for International Arms Transfers in the Context of General Assembly Resolution 46/36 H of 6 December 1991), 24-25, 39.

${ }^{167}$ Norwegian Initiative for Small Arms Trade (NISAT), "Elements of a Common Understanding."

${ }^{168}$ The Fund for Peace, "Model Convention on the Registration of Arms Brokers and the Suppression of Unlicensed Arms Brokering." Hereafter this will be referred to as the 'Model Convention on Brokering.'

${ }^{169}$ Godnick, The Organisation of American States and the 2001 United Nations Conference on the Illicit Trade in Small Arms and Light Weapons in all Aspects: Tackling the Illicit Trade in Small Arms and Light Weapons.

${ }^{170}$ Yankey-Wayne, "Widening Our Understanding of the Brokering Issue: Key Developments.”
} 
issue to the general public's attention, with its star Nicolas Cage working with Amnesty International on the issue. ${ }^{171}$

After this slow start, a plethora of small arms control mechanisms came into existence after the 2001 Programme of Action, which says that states ought to

... develop adequate national legislation or administrative procedures regulating the activities of those who engage in [SALW] brokering ... such as registration of brokers, licensing or authorization of brokering transactions as well as the appropriate penalties for all illicit brokering activities performed within the State's jurisdiction ... ${ }^{172}$

Many of these later control mechanisms did include brokering. Some of these mechanisms mention brokering regulation briefly, such as the Wassenaar Arrangement's Best Practice Guidelines for Exports of Small Arms and Light Weapons and the OAS Model Regulations. ${ }^{173}$ Others, like the Wassenaar Arrangement's Elements for Effective Legislation on Arms Brokering, addressed it more specifically. ${ }^{174}$ These elaborations indicate some acceptance of the norm to

\footnotetext{
${ }^{171}$ Stohl, Stohl, and Stohl, "Linking Small Arms, Child Soldiers, NGOs and Citizen Diplomacy: Nicolas Cage and the Lord of War." Cage affiliated himself with Amnesty International and the Control Arms Campaign, although this link was somewhat short-lived.

${ }^{172}$ United Nations Department for Disarmament Affairs, "Programme of Action to Prevent, Combat and Eradicate the Illicit Trade in Small Arms and Light Weapons in All Its Aspects," II, IV.
}

${ }^{173}$ Andean Community, Decision 552: Andean Plan to Prevent, Combat and Eradicate Illicit Trade in Small Arms and Light Weapons in all its Aspects (and Annexes); Council of the European Union, EU Strategy to Combat Illicit Accumulation and Trafficking of SALW and Their Ammunition; Economic Community of West African States (ECOWAS), ECOWAS Convention on Small Arms and Light Weapons, Their Ammunition and Other Related Materials; Inter-American Drug Abuse Control Commission, Model Regulations for the Control of the International Movement of Firearms, their Parts And Components and Ammunition - Updated; Nicaragua, "Working Paper Submitted by Nicaragua: Code of Conduct of Central American States on the Transfer of Arms, Ammunition, Explosives and Other Related Materiel (A/CONF.192/2006/RC/WP.6)"; Organisation for Security and Cooperation in Europe (OSCE), OSCE Document on Small Arms and Light Weapons; Republic of Burundi et al., The Nairobi Protocol for the Prevention, Control and Reduction of Small Arms and Light Weapons in the Great Lakes Region and the Horn of Africa; Southern African Development Community, Protocol on the Control of Firearms, Ammunition and Other Related Materials in the Southern African Development Community (SADC) Region; United Nations General Assembly, Protocol against the Illicit Manufacturing of and Trafficking in Firearms, Their Parts and Components and Ammunition, supplementing the United Nations; Wassenaar Arrangement Secretariat, The Wassenaar Arrangement on Export Controls for Conventional Arms and Dual-Use Goods and Technologies. Basic Documents, 22-29, 35-39.

${ }^{174}$ Organisation for Security and Cooperation in Europe (OSCE), “OSCE Handbook of Best Practices on Small Arms and Light Weapons. Decision No. 5/03 Best Practice Guides on Small Arms and Light 
regulate brokering by 2006, when the United Nations General Assembly passed Resolution 61/89, entitled Towards an Arms Trade Treaty. ${ }^{175}$

\section{The norm regulating brokering in relation to the Arms Trade Treaty}

The first resolution on a potential Arms Trade Treaty, Resolution 61/89

Towards an Arms Trade Treaty, requested that states respond to the SecretaryGeneral's request for their views on the "feasibility, scope and draft parameters" of such an instrument. ${ }^{176}$ Their responses can be found in a series of documents numbered $\mathrm{A} / 62 / 278^{177}$, and Parker also took these states responses and collated them into two reports titled Analysis of States' Views on an Arms Trade Treaty and Implications of States' Views on an Arms Trade Treaty. ${ }^{178}$ The Resolution also established a Group of Experts on the same subject with a mandate to report back,

\footnotetext{
Weapons"; Wassenaar Arrangement Secretariat, The Wassenaar Arrangement on Export Controls for Conventional Arms and Dual-Use Goods and Technologies. Basic Documents.

${ }^{175}$ United Nations General Assembly, Towards an Arms Trade Treaty: Establishing Common International Standards for the Import, Export and Transfer of Conventional Arms.

176 Ibid.

${ }^{177}$ United Nations General Assembly, Towards an Arms Trade Treaty: Establishing Common International Standards for the Import, Export and Transfer of Conventional Arms.; United Nations General Assembly, Towards an Arms Trade Treaty: Establishing Common International Standards for the Import, Export and Transfer of Conventional Arms.; United Nations General Assembly, Towards an Arms Trade Treaty: Establishing Common International Standards for the Import, Export and Transfer of Conventional Arms. (Addendum); United Nations General Assembly, Towards an Arms Trade Treaty: Establishing Common International Standards for the Import, Export and Transfer of Conventional Arms. (Addendum); United Nations General Assembly, Towards an Arms Trade Treaty: Establishing Common International Standards for the Import, Export and Transfer of Conventional Arms. (Addendum); United Nations General Assembly, Towards an Arms Trade Treaty: Establishing Common International Standards for the Import, Export and Transfer of Conventional Arms. (Addendum).

${ }^{178}$ Parker, Analysis of States' Views on an Arms Trade Treaty; Parker, Implications of States' Views on an Arms Trade Treaty. Hereafter these reports will be referred to as 'Analysis of States' Views Report' and 'Implications of States' Views Report'. Note: Parker adds a caveat to her initial report: "states were free to include or omit whatever issues, themes and categories they chose. For example, simply because they did not express support in their submission for the inclusion of a reporting mechanism does not mean that they would oppose such." Therefore figures given indicate a minimum level of support from states. Parker, Analysis of States' Views on an Arms Trade Treaty, 3.
} 
which they did in the 2007 Group of Experts Report A/63/334, based on their own expert knowledge ${ }^{179}$, and on the work of experts from UNIDIR. ${ }^{180}$

At the most recent Arms Trade Treaty PrepCom, brokering was mentioned by a number of states, although it is difficult to be specific about the figures as some statements contained implicit references to brokering. ${ }^{181}$ In addition, some of those states that mentioned brokering did not support it. ${ }^{182}$ However, this notwithstanding, there is some consensus being established among states on what constitutes a broker and their associated activities, in terms of a definition. Other mechanisms have

\footnotetext{
${ }^{179}$ United Nations General Assembly, Report of the Group of Governmental Experts to Examine the Feasibility, Scope and Draft Parameters for a Comprehensive, Legally Binding Instrument Establishing Common International Standards for the Import, Export and Transfer of Conventional Arms. Hereafter this will be referred to as the Group of Experts Report.

${ }^{180}$ Parker, Analysis of States' Views on an Arms Trade Treaty; Parker, Implications of States' Views on an Arms Trade Treaty; United Nations General Assembly, Report of the Group of Governmental Experts to Examine the Feasibility, Scope and Draft Parameters for a Comprehensive, Legally Binding Instrument Establishing Common International Standards for the Import, Export and Transfer of Conventional Arms, 11.
}

${ }^{181}$ Author's notes from PrepCom Day 1, afternoon session; Author's notes from PrepCom Day 2, morning session; Author's notes from PrepCom Day 2, afternoon session; Author's notes from PrepCom Day 3, morning session; Author's notes from PrepCom Day 3, afternoon session; Author's notes from PrepCom Day 4, morning session; Author's notes from PrepCom Day 5, morning session; Abelson, "Statement by Ms. Annette Abelson, Head of Delegation, Norway"; Argentina et al., "Joint Statement on Elements for a Treaty"; Boon, "Statement of Colonel Lim Yoon Boon, Military Adviser, Permanent Mission of Singapore to the United Nations"; Charles, "Facilitator's Summary for Scope"; Delegation of the Russian Federation, "Elements to be Discussed in the Context of a Potential ATT. Introductory Remarks by the Delegation of the Russian Federation"; Delegation of the Russian Federation, "Towards an Arms Trade Treaty - Goals and Objectives (Non-Paper)"; Momen, "Statement by Dr A.K. Abdul Momen, Permanent Representative of Bangladesh to the United Nations"; Obisakin, "Statement of the African Group delivered by Lawrence Olufemi Obisakin, Minister, Permanent Mission of Nigeria to the UN, at the First Session of the Preparatory Committee for the United Nations Conference on the Arms Trade Treaty”; Moritán, “Chairman's Draft Paper - 22 July 2010"; Williams, "Statement by Mr Deon Lloyd Williams, Counsellor, Permanent Mission of Jamaica to the United Nations." Note: France, Israel, Morocco, Nicaragua and Portugal referred to illicit trafficking and these have been included as 'brokering'. Due to the language used for the official statements, combined with my inability to attend some of the sessions of the first PrepCom, some statements from the first PrepCom have not been included. These are available at http://www.un.org/disarmament/convarms/ATTPrepCom/Statements-MemberStates.html. Additionally, several regional statements were made on brokering. Economic Community of West African States (ECOWAS), "Statement by Economic Community of West African States"; Caribbean Community, "Statement on Behalf of CARICOM Member States by H.E. Henry MacDonald, Permanent Representative of Suriname to the United Nations at the First Session of the Preparatory Committee of the United Nations on the Arms Trade Treaty."; Bauwens, "Statement by H.E. Mr Werner Bauwens, Special Envoy for Disarmament and Non-Proliferation, European Union. EU Statement on the Goals and Objectives of an ATT."

${ }^{182}$ Delegation of Israel, "Statement made by Israel at the Preparatory Committee for the United Nations Conference on the Arms Trade Treaty." 
defined brokers and their actions in a variety of ways ${ }^{183}$, thus several states specifically remarked in their responses to Resolution $61 / 89$ on the need for a clear definition of brokering activities. ${ }^{184}$ During the first PrepCom states continued to bring the issue up, as it pertains to the scope of the Treaty, and most states believed that a precise definition was needed. ${ }^{185}$ None of the outcome documents from the first PrepCom defined brokering but the Facilitator's Summary for Scope noted that a number of states used the Experts Report on Brokering definition of brokers and brokering, as outlined earlier. ${ }^{186}$

The norm continues to develop as it appears in the context of the ATT with two distinct themes emerging during the brokering debate on the Arms Trade Treaty. The dominant theme was illicit brokering, and the secondary theme was whether to include the norm within the ATT at all.

\section{Illicit brokering}

The theme that emerged most clearly in ATT discussions was that of taking action against illicit brokering, which is entwined with the first two requirements of the brokering norm. Debates were strongly influenced by differing underlying

\footnotetext{
${ }^{183}$ The Fund for Peace, "Model Convention on the Registration of Arms Brokers and the Suppression of Unlicensed Arms Brokering," 2; United Nations Department for Disarmament Affairs, "Programme of Action to Prevent, Combat and Eradicate the Illicit Trade in Small Arms and Light Weapons in All Its Aspects," II; United Nations General Assembly, Protocol against the Illicit Manufacturing of and Trafficking in Firearms, Their Parts and Components and Ammunition, supplementing the United Nations, para. 15; Wassenaar Arrangement Secretariat, The Wassenaar Arrangement on Export Controls for Conventional Arms and Dual-Use Goods and Technologies. Basic Documents, 36.

${ }^{184}$ United Nations General Assembly, Towards an Arms Trade Treaty: Establishing Common International Standards for the Import, Export and Transfer of Conventional Arms., 7; United Nations General Assembly, Towards an Arms Trade Treaty: Establishing Common International Standards for the Import, Export and Transfer of Conventional Arms., 9, 21-22, 89, 101, 185, 198, 207.

${ }^{185}$ Author's notes from PrepCom Day 2, morning session; Author's notes from PrepCom Day 2, afternoon session; Author's notes from PrepCom Day 3, morning session; Author's notes from PrepCom Day 4, morning session.

${ }^{186}$ Charles, "Facilitator's Summary for Scope." Note: Brokering was defined at the second PrepCom in February/March 2011. Moritán, "Chairman’s Draft Paper - 3 March 2010 [sic]."
} 
positions on national security and human security. The impact of concerns voiced about terrorism, in relation to these and other conventional weapons, also affected this norm. Prior to the first PrepCom, it was clear that the norm regulating brokering was emergent but that its detail was still being decided.

During the first PrepCom debate, two sides emerged: those states that wished to restrict the Treaty to regulating and sanctioning illicit actors and actions; and those who wanted a more comprehensive instrument to regulate brokering. These latter states argue that weapons are often diverted from the legal trade; therefore it makes sense to incorporate both licit and illicit brokering, to address the issue completely to ensure human security from all 'irresponsible' arms transfers. Many states that referred to the regulation of brokering norm are already known as norm promoters in the field of peace and disarmament, and other states have emerged as particular supporters of the Arms Trade Treaty initiative and therefore many of the norms in the cluster. ${ }^{187}$ In addition, many of these states are members of organisations which have regulatory mechanisms which include brokering, for example the SADC Protocol. ${ }^{188}$ Their statements thus reinforce their previously noted positions and extend them to the context of an ATT. ${ }^{189}$ These states have continued to promote the

${ }^{187}$ Erickson, "When Do the Takers Become the Makers? The Promotion of 'Responsible Arms Trade' Norms." Examples of these states include Colombia, England, Germany, and South Africa.

${ }^{188}$ Southern African Development Community, Protocol on the Control of Firearms, Ammunition and Other Related Materials in the Southern African Development Community (SADC) Region; Wassenaar Arrangement Secretariat, The Wassenaar Arrangement on Export Controls for Conventional Arms and Dual-Use Goods and Technologies. Basic Documents.

${ }^{189}$ Author's notes from PrepCom Day 1, afternoon session; Author's notes from PrepCom Day 2, morning session; Author's notes from PrepCom Day 2, afternoon session; Author's notes from PrepCom Day 3, morning session; Author's notes from PrepCom Day 3, afternoon session; Author's notes from PrepCom Day 4, morning session; Author's notes from PrepCom Day 5, morning session; Argentina et al., "Joint Statement on Elements for a Treaty"; Delegation of Ireland, "Scope of a Potential Arms Trade Treaty"; Delegation of the Russian Federation, "Elements to be Discussed in the Context of a Potential ATT. Introductory Remarks by the Delegation of the Russian Federation"; Delegation of the Russian Federation, "Towards an Arms Trade Treaty - Goals and Objectives (NonPaper)"; Duncan, "Open-Ended Working Group: Towards an Arms Trade Treaty. Intervention by Ambassador John Duncan, 4 March 2009. Scope of a Potential Arms Trade Treaty”; Petlyakov, "Regarding the Aims and Purposes of an International Arms Trade Treaty. Statement by Sergey Y 
more robust position of including all brokering, with support from a number of NGOs which attended the first PrepCom. Organisations such as Amnesty International spoke about the importance of human security which can only be gained from a strong Treaty which incorporates regulation of all transfers, including brokering and other "irresponsible" transfers. ${ }^{190}$ Some states have also supported human security in relation to the ATT. ${ }^{191}$

A large number of the states that promoted the broader norm regulating brokering in the Arms Trade Treaty have a vested interest in preventing small arms proliferation by brokers, because of their own experiences with armed violence and

Petlyakov (Russian Federation)"; United Nations General Assembly, Towards an Arms Trade Treaty: Establishing Common International Standards for the Import, Export and Transfer of Conventional Arms.; United Nations General Assembly, Towards an Arms Trade Treaty: Establishing Common International Standards for the Import, Export and Transfer of Conventional Arms.; United Nations General Assembly, Towards an Arms Trade Treaty: Establishing Common International Standards for the Import, Export and Transfer of Conventional Arms. (Addendum); United Nations General Assembly, Towards an Arms Trade Treaty: Establishing Common International Standards for the Import, Export and Transfer of Conventional Arms. (Addendum).

${ }^{190}$ Author's notes form PrepCom Day 5, morning session; Amnesty International, Deadly Movements: Arms Transportation Controls in the Arms Trade Treaty; Cairns, "Dying for Action: Decision Time for an Urgent, Effective Arms Trade Treaty"; Control Arms Campaign, The G8: Global Arms Exporters. Failing to Prevent Irresponsible Arms Transfers; Control Arms Campaign, Arms Without Borders: Why a Globalised Trade Needs Global Controls; Higgie, "Statement by Ambassador Dell Higgie, Permanent Representative to the United Nations in Geneva, New Zealand"; Obisakin, "Statement of the African Group delivered by Lawrence Olufemi Obisakin, Minister, Permanent Mission of Nigeria to the UN, at the First Session of the Preparatory Committee for the United Nations Conference on the Arms Trade Treaty"; Parker, Implications of States' Views on an Arms Trade Treaty; United Nations General Assembly, Towards an Arms Trade Treaty: Establishing Common International Standards for the Import, Export and Transfer of Conventional Arms.; United Nations Institute for Disarmament Research (UNIDIR) and European Union, "Promoting Discussion on an Arms Trade Treaty - European Union-UNIDIR Project Regional Seminar for Countries in Central, Northern and Western Africa. Summary Report"; United Nations Institute for Disarmament Research (UNIDIR) and European Union, "Promoting Discussion on an Arms Trade Treaty European Union-UNIDIR Project Regional Seminar for Countries in the Americas and the Caribbean. Summary Report"; United Nations Institute for Disarmament Research (UNIDIR) and European Union, "Promoting Discussion on an Arms Trade Treaty - European Union-UNIDIR Project Regional Seminar for Countries in the Middle East. Summary Report"; Wieland, "Statement on Behalf of Austria by Mr. Christoph Wieland, Counsellor at the Austrian Mission to the UN."

${ }^{191}$ Duncan, "Open-Ended Working Group: Towards an Arms Trade Treaty. Intervention by Ambassador John Duncan, 4 March 2009. Scope of a Potential Arms Trade Treaty"; Yanai, "Statement on 'Goals and Objectives of a Feasible Arms Trade Treaty' by Ms Keiko Yanai, Ministry of Foreign Affairs, Japan." 
conflict. ${ }^{192}$ Representatives of African states spoke about brokering as something which exacerbates conflict and undermines UN embargoes, human rights and socioeconomic development. ${ }^{193}$ They were particularly concerned with preventing the supply of these weapons to areas in conflict or post-conflict situations, as small arms are used to violate human rights and contribute to under-development and human insecurity as well as increasing the lethality of a conflict. ${ }^{194}$ There is a recognition that small arms and light weapons, in particular, are easy to obtain from brokers. Other states which supported a comprehensive approach to brokering in the ATT, from South America and the Caribbean, linked the conflict with illegal criminal actions such as gang violence and drug trafficking, also because of their experiences ${ }^{195}$. Many of these South American and Caribbean states have been the

\footnotetext{
${ }^{192}$ Amnesty International, Blood at the Crossroads: Making the Case for a Global Arms Trade Treaty; Amnesty International, Amnesty International Report 2010: State of the World's Human Rights; Control Arms Campaign, The G8: Global Arms Exporters. Failing to Prevent Irresponsible Arms Transfers; Control Arms Campaign, Arms Without Borders: Why a Globalised Trade Needs Global Controls; Geneva Declaration Secretariat, The Global Burden of Armed Violence; Godnick, The Organisation of American States and the 2001 United Nations Conference on the Illicit Trade in Small Arms and Light Weapons in all Aspects: Tackling the Illicit Trade in Small Arms and Light Weapons.; Godnick and Vàzquez, Small Arms Control in Latin America; Husain, Armed and Dangerous: Small Arms and Explosives Trafficking in Bangladesh; International Crisis Group, "Illicit Arms in Indonesia"; Momen, "Statement by Dr A.K. Abdul Momen, Permanent Representative of Bangladesh to the United Nations."

${ }^{193}$ Author's notes from PrepCom Day 1, afternoon session; Author's notes form PrepCom Day 2, morning session; Economic Community of West African States (ECOWAS), "Statement by Economic Community of West African States"; United Nations General Assembly, Towards an Arms Trade Treaty: Establishing Common International Standards for the Import, Export and Transfer of Conventional Arms.; United Nations General Assembly, Towards an Arms Trade Treaty: Establishing Common International Standards for the Import, Export and Transfer of Conventional Arms.; United Nations General Assembly, Towards an Arms Trade Treaty: Establishing Common International Standards for the Import, Export and Transfer of Conventional Arms. (Addendum).
}

${ }^{194}$ Amnesty International, Dead on Time - Arms Transportation, Brokering and the Threat to Human Rights; Amnesty International, Amnesty International Report 2010: State of the World's Human Rights; Geneva Declaration Secretariat, The Global Burden of Armed Violence; United Nations Institute for Disarmament Research (UNIDIR) and European Union, "Promoting Discussion on an Arms Trade Treaty - European Union-UNIDIR Project Regional Seminar for Countries in Central, Northern and Western Africa. Summary Report"; United Nations Institute for Disarmament Research (UNIDIR) and European Union, "Promoting Discussion on an Arms Trade Treaty - European UnionUNIDIR Project Regional Seminar for Countries in Eastern and Southern Africa. Summary Report."

${ }^{195}$ Caribbean Community, "Statement on Behalf of CARICOM Member States by H.E. Henry MacDonald, Permanent Representative of Suriname to the United Nations at the First Session of the Preparatory Committee of the United Nations on the Arms Trade Treaty."; Epps, Towards Global Standards: Regional Experience in Small Arms Transfer Controls. Edited Papers from an 
'victims' of brokers in small arms because of their proximity to the US and the porous border. ${ }^{196}$ Looking at these countries' statements, brokering is spoken about in terms of establishing criminal sanctions, preventing corruption and preventing diversion from the legal trade, but still reflects a concern about human insecurity as a result of under-development due to armed violence. These states have attempted to shape the inclusion of a broad norm regulating brokering in the ATT by appealing to human security norms and are supported by credible NGOs with evidence on the effects of brokering.

Of the states that focussed their submissions on illicit brokering, the US was a key proponent, albeit not the most vocal on the issue, because of its broader influence in international politics. The 2009 decision by the US to support the ATT, a watershed moment for the Treaty, was partly made because of the Obama Administration's decision to change national security policies generally ${ }^{197}$. More clearly at work however, was the stated belief that creating such "high international standards" will decrease access to weapons for "rogue states, terrorist groups, and groups seeking to unsettle regions". ${ }^{198}$ Since $9 / 11$, the US has become very concerned about the ability of 'rogue' actors and terrorists to access various types of weapons

International Seminar.; Greene, "Examining International Responses to Illicit Arms Trafficking”; United Nations Institute for Disarmament Research (UNIDIR) and European Union, "Promoting Discussion on an Arms Trade Treaty - European Union-UNIDIR Project Regional Seminar for Countries in the Americas and the Caribbean. Summary Report."

${ }^{196}$ Degia, "Intervention by Mr. Mohammed Iqbal Degia, First Secretary, Permanent Mission of Barbados to the United Nations on behalf of CARICOM, on the theme of Other issues, and identification of priority issues or topics of relevance in the illicit trade in small arms and light weapons in all its aspects and of their implementation challenges and opportunities"; Horwitz and Grimaldi, "NRA-led gun lobby wields powerful influence over ATF, U.S. politics"; Stohl and Tuttle, "The Small Arms Trade in Latin America."

${ }^{197}$ Clinton, "U.S. Support for the Arms Trade Treaty"; Mohammed, "U.S. Reverses Stance on Treaty to Regulate Arms Trade." It can be identified as the 'tipping point' for the Arms Trade Treaty norm cluster, with the US being the 'critical' state that needed to be persuaded.

${ }^{198}$ Clinton, "U.S. Support for the Arms Trade Treaty." 
and weaken national security, including on its own southern border. ${ }^{199}$ The US has strong weapons export controls, and justifies its position on regulating illicit brokering at the first PrepCom by blaming this practice for its weapons being found in the hands of those it has deemed terrorists. ${ }^{200}$ This is reinforced by its prosecution of several brokers like Montesinos and al Kassar under counter-terrorism legislation. Counter-terrorism measures have also included prevention of illicit brokering efforts in other arms control areas, notably supporting the landmark UN Security Council Resolutions 1373 and $1540 .{ }^{201}$ However regulation of illicit brokering allows for the continuation of licit brokering, and these kinds of weapons transfers have been used to stabilise a 'region under threat' or to shore up support for on-going military action. ${ }^{202}$ The US has disputed the need for a comprehensive norm regulating brokering because it seeks to continue this type of transfer to its allies. The US decides which regimes it believes are 'legitimate' and has coordinated action against those which do not meet the criteria, including by arming NSAs involved in the conflict. ${ }^{203}$ It sees itself as the arbiter of international relations, persuading other states to back its actions, such as in Iraq and Afghanistan, where it controversially supported NSAs against the 'repressive' leadership. ${ }^{204}$ This explains why there has

\footnotetext{
${ }^{199}$ Kessler, "Weapons Given to Iraq Are Missing - GAO Estimates 30\% of Arms Are Unaccounted For"; Sheridan, "Despite Obama Pledge, Democrats Show Little Enthusiasm for CIFTA Treaty on Gun Trafficking." The intense response by the US to these terrorist acts can be seen in the 2002 National Security Strategy and its precursor, the 2001 USA PATRIOT Act. United States of America, Uniting and Strengthening America by Providing Appropriate Tools Required to Intercept and Obstruct Terrorism (USA PATRIOT ACT) Act of 2001; United States of America, "The National Security Strategy of the United States of America."

${ }^{200}$ Author's notes from PrepCom Day 2, afternoon session; United Nations General Assembly, Towards an Arms Trade Treaty: Establishing Common International Standards for the Import, Export and Transfer of Conventional Arms. (Addendum).

${ }^{201}$ United Nations Security Council, United Nations Security Council Resolution 1373; United Nations Security Council, United Nations Security Council Resolution 1540.

${ }^{202}$ Shapiro, "Briefing on Pending Major Arms Sale."

${ }^{203}$ Stohl, "Questionable Reward: Arms Sales and the War on Terrorism."

${ }^{204}$ See for example Caraley, American Hegemony: Preventive War, Iraq, and Imposing Democracy; Rall, Gas War: The Truth Behind the American Occupation of Afghanistan.
} 
been no mention of comprehensive brokering regulation by the United States, despite

its experiences with brokers like Bout and Montesinos.

States which have valid concerns about terrorism in their states, having experienced it, raised this issue at the first ATT PrepCom with reference to brokering. Indonesia, which has concerns about real or potential illicit weapons transfers in relation to terrorism, linked the two in ATT discussions, as have other states like India and Pakistan. ${ }^{205}$ While not mentioning brokering specifically, a number of states acknowledged that illicit transfers have contributed to terrorism both at the first PrepCom ${ }^{206}$ and in previous statements. ${ }^{207}$ Many states are aware of the US position on terrorism and thus are susceptible to its muted norm promotion. Several of them have gained weapons and financial assistance for supporting the

\begin{abstract}
${ }^{205}$ Author's notes from PrepCom Day 2, morning session; Author's notes from PrepCom Day 4, morning session; Higgie, "Statement by Ambassador Dell Higgie, Permanent Representative to the United Nations in Geneva, New Zealand"; International Crisis Group, "Illicit Arms in Indonesia"; Permanent Mission of the Philippines to the United Nations, "Philippine Position on the Geneva Declaration on Armed Violence and Development"; Petlyakov, "Regarding the Aims and Purposes of an International Arms Trade Treaty. Statement by Sergey Y Petlyakov (Russian Federation)"; United Nations General Assembly, Towards an Arms Trade Treaty: Establishing Common International Standards for the Import, Export and Transfer of Conventional Arms.; United Nations General Assembly, Towards an Arms Trade Treaty: Establishing Common International Standards for the Import, Export and Transfer of Conventional Arms.; United Nations General Assembly, Towards an Arms Trade Treaty: Establishing Common International Standards for the Import, Export and Transfer of Conventional Arms. (Addendum); United Nations General Assembly, Towards an Arms Trade Treaty: Establishing Common International Standards for the Import, Export and Transfer of Conventional Arms. (Addendum); United Nations General Assembly, Towards an Arms Trade Treaty: Establishing Common International Standards for the Import, Export and Transfer of Conventional Arms. (Addendum).
\end{abstract}

${ }^{206}$ Author's notes from PrepCom Day 1, afternoon session; Author's notes from PrepCom Day 2, morning session; Author's notes from PrepCom Day 2, afternoon session; Author's notes from PrepCom Day 3, morning session; Author's notes from PrepCom Day 4, morning session; Author's notes from PrepCom Day 5, morning session; Bauwens, "Statement by H.E. Mr Werner Bauwens, Special Envoy for Disarmament and Non-Proliferation, European Union. EU Statement on the Goals and Objectives of an ATT"; Bauwens, "Statement by H.E. Mr Werner Bauwens, Special Envoy for Disarmament and Non-Proliferation, European Union. EU Statement on the Principles Governing the Arms Trade Treaty"; Delegation of the Russian Federation, "Elements to be Discussed in the Context of a Potential ATT. Introductory Remarks by the Delegation of the Russian Federation"; Obisakin, "Statement delivered by Lawrence Olufemi Obisakin, Minister, Permanent Mission of Nigeria to the UN."

${ }^{207}$ Parker, Analysis of States' Views on an Arms Trade Treaty; Parker, Implications of States' Views on an Arms Trade Treaty; United Nations General Assembly, Towards an Arms Trade Treaty: Establishing Common International Standards for the Import, Export and Transfer of Conventional Arms.; United Nations General Assembly, Towards an Arms Trade Treaty: Establishing Common International Standards for the Import, Export and Transfer of Conventional Arms. 
US's anti-terrorism stance, in addition to being brought back within the US circle of legitimacy. ${ }^{208}$ Some of these have not experienced incidents of terrorism, for example New Zealand and Norway, which indicates the strength of the links being made between the Treaty and terrorism. ${ }^{209}$ The EU also supports the inclusion of terrorism in the ATT, evidence of a move towards supporting illicit brokering, rather than taking a more comprehensive approach. ${ }^{210}$ Its member states have experienced terrorism and some of the brokering cases touched on here have included European citizens or have a European connection. ${ }^{211}$ The EU has also moved to support illicit brokering because of its apparent dilemma between continuing to allow its members' lucrative weapons exports, which could be brokered either legally or illicitly to others, and its sensibility of the need to provide human security which it champions. ${ }^{212}$ Member states of the EU and potential members have made billions of dollars from exporting weapons and weapons technology. In addition, these states wish to retain their ability to legally transfer weapons to specific NSAs, in a policy

\footnotetext{
${ }^{208}$ Stohl, "Questionable Reward: Arms Sales and the War on Terrorism"; United Nations Security Council, United Nations Security Council Resolution 1373; United Nations Security Council, United Nations Security Council Resolution 1540.

${ }^{209}$ Abelson, "Statement by Ms. Annette Abelson, Head of Delegation, Norway"; Higgie, "Statement by Ambassador Dell Higgie, Permanent Representative to the United Nations in Geneva, New Zealand."

${ }^{210}$ Bauwens, "Statement by H.E. Mr Werner Bauwens, Special Envoy for Disarmament and NonProliferation, European Union. EU Statement on the Goals and Objectives of an ATT"; Clarke, Transnational Advocacy Coalitions and Human Security Initiatives: Explaining Success and Failure.

${ }^{211}$ Amnesty International, "Italian Courts Release Arms Dealer"; Amnesty International, Deadly Movements: Arms Transportation Controls in the Arms Trade Treaty; Brunwasser, "Gunrunners: Gallery of International Arms Dealers - Leonid Efimovich Minin"; Control Arms Campaign, The G8: Global Arms Exporters. Failing to Prevent Irresponsible Arms Transfers.

${ }^{212}$ Amnesty International, Dead on Time - Arms Transportation, Brokering and the Threat to Human Rights; Bauwens, "Statement by H.E. Mr Werner Bauwens, Special Envoy for Disarmament and Non-Proliferation, European Union. EU Statement on the Principles Governing the Arms Trade Treaty"; Clarke, Transnational Advocacy Coalitions and Human Security Initiatives: Explaining Success and Failure; Control Arms Campaign, The G8: Global Arms Exporters. Failing to Prevent Irresponsible Arms Transfers; Segell, "Terrorism: London Public Transport - July 7, 2005."
} 
similar to that of the US, to enable them to oppose tyrannical governments. ${ }^{213}$ This has prompted them to support the reframing of the norm towards regulating illicit brokering. Support from such a large number of powerful states, in the United Nations Security Council and outside it, has provided a tipping point for the norm, with other states moving towards this position in closed session discussion as evidenced by the Chairman's Draft Paper. ${ }^{214}$

The delegation of the Russian Federation made references to the need to regulate brokering which reflect "weak links" in the legal trade. ${ }^{215}$ It stated that

Check-ups we conducted ... showed that the arms found in embargo areas came from other countries' territories. Those arms were either imported from Russia or the USSR in earlier years or manufactured without licences or under expired licenses ... ${ }^{216}$

Further statements made by the Russian Federation continue to place brokering controls within the context of preventing illicit diversion with regard to conflict (rather than terrorism). ${ }^{217}$ Russia is a major importer and exporter of small arms, and wishes to retain its right to trade with few restrictions, holding to the position that defence transfers are internal decisions and outside the UN jurisdiction. It has worked hard for some years to prevent Bout, a Russian resident, from being

\footnotetext{
${ }^{213}$ Council of the European Union, European Code of Conduct on Arms Exports; Frey, Progress Report of Barbara Frey, Special Rapporteur on the Prevention of Human Rights Violations Committed with Small Arms and Light Weapons.

${ }^{214}$ Moritán, “Chairman's Draft Paper - 22 July 2010."

${ }^{215}$ Author's notes from PrepCom Day 3, morning session; Author's notes from PrepCom Day 5, morning session; Delegation of the Russian Federation, "Elements to be Discussed in the Context of a Potential ATT. Introductory Remarks by the Delegation of the Russian Federation"; Delegation of the Russian Federation, "Towards an Arms Trade Treaty - Goals and Objectives (Non-Paper)"; Petlyakov, "Regarding the Aims and Purposes of an International Arms Trade Treaty. Statement by Sergey Y Petlyakov (Russian Federation)."

${ }^{216}$ Petlyakov, "Regarding the Aims and Purposes of an International Arms Trade Treaty. Statement by Sergey Y Petlyakov (Russian Federation).”

${ }^{217}$ Delegation of the Russian Federation, "Elements to be Discussed in the Context of a Potential ATT. Introductory Remarks by the Delegation of the Russian Federation"; Delegation of the Russian Federation, "Towards an Arms Trade Treaty - Goals and Objectives (Non-Paper)"; International Peace Institute and Wulf, Task Force One: Transnational Security Challenges - Small Arms \& Light Weapons. Non-Paper for Opening Plenary Meeting.
} 
extradited and tried for illicit brokering. ${ }^{218}$ This supports claims that it wishes to keep the ATT focussed on illicit brokering ${ }^{219}$, and away from questions about who is legally being supplied by the Russian Federation with weapons and the implications of this for human security. Similarly, China argues that states should 'crack down' on illicit trading and that exports of arms ought to be undertaken with the legitimate self-defence needs of the importing state in mind and not used to undermine state sovereignty. ${ }^{220}$ China continues to export weapons to a number of states and actors which have questionable human rights records or are in conflict, appearing to reject the concept of 'responsible' transfers as defined by other states. ${ }^{221}$ Both China and Russia contest the need for a comprehensive norm regulating brokering.

Other states share China's concerns that state sovereignty and the right to manufacture and export weapons will be eroded by an ATT which includes strict regulation on brokering. India wished to keep discussion about the ATT on the 'illegal trade', claiming that it damages economic growth as well as peace and security, which Pakistan agrees with. ${ }^{222}$ Both these states have been increasingly involved in the profitable conventional arms trade, and argue that allowing only some states to benefit from such trading is inequitable. Various other states reiterated concerns about self-defence capabilities being undermined by an ATT, particularly if

\footnotetext{
${ }^{218}$ Brunwasser, “Gunrunners: Gallery of International Arms Dealers - Victor Anatoleyevich Bout.”

${ }^{219}$ International Peace Institute and Wulf, Task Force One: Transnational Security Challenges - Small Arms \& Light Weapons. Non-Paper for Opening Plenary Meeting, 3.

${ }^{220}$ Author's notes from PrepCom Day 1, afternoon session; Author's notes from PrepCom Day 3 , morning session; United Nations General Assembly, Towards an Arms Trade Treaty: Establishing Common International Standards for the Import, Export and Transfer of Conventional Arms.

${ }^{221}$ Control Arms Campaign, Arms Without Borders: Why a Globalised Trade Needs Global Controls; Graduate Institute of International and Development Studies, Small Arms Survey 2009: Shadows of War, chap. 1; Greene and Kirkham, Preventing Diversion of Small Arms and Light Weapons: Issues and Priorities for Strengthened Controls.

${ }^{222}$ Author's notes from PrepCom Day 1, afternoon session; Author's notes from PrepCom Day 2, morning session; Author's notes from PrepCom Day 3, morning session; Akram, "Statement by Ambassador Zamir Akram, Permanent Representative of Pakistan to the United Nations, Geneva, in the First Committee."
} 
it was 'discriminatory'. ${ }^{223}$ At previous discussions on the Arms Trade Treaty, Middle Eastern states mentioned their belief that there is only a small illicit trade based on "smuggling, cases of diversion, uncontrolled civilian weapons and loopholes in border controls". ${ }^{224}$ These states are traditionally anti-intervention in any form, believing that state sovereignty and non-intervention as laid out in the UN Charter are sacrosanct. ${ }^{225}$ Several have also experienced challenges to their authority from NSAs. Submissions from both France and Israel focussed on preventing "illicit trafficking" and ensuring that licit brokering for self-defence was allowed. ${ }^{226}$ The primacy of the state and its security over human security is clear, as these states continued to urge each other at the first PrepCom not to undermine the legal trade and principles of non-intervention by regulating all brokering.

Contestation of the content of the norm regulating brokering had a clear impact on the Treaty discussions involving brokering in the closed sessions, wherein states focussed on its scope, parameters, and implementation and application, as illustrated by the contents of the papers distributed by the Chair's 'Friends'. ${ }^{227}$ The Chairman's Draft Paper, the final outcome document of the first PrepCom, specifically lists brokering among the elements to be included in an Arms Trade

\footnotetext{
${ }^{223}$ Author's notes from PrepCom Day 1, afternoon session; Author's notes from PrepCom Day 2, morning session; Author's notes from PrepCom Day 2, afternoon session; Author's notes from PrepCom Day 3, morning session; Author's notes from PrepCom Day 3, afternoon session; Author's notes from Day 4, morning session; Author's notes from Day 5, morning session.

${ }^{224}$ United Nations Institute for Disarmament Research (UNIDIR) and European Union, "Promoting Discussion on an Arms Trade Treaty - European Union-UNIDIR Project Regional Seminar for Countries in the Middle East. Summary Report."

${ }^{225}$ United Nations, The Charter of the United Nations. Articles 2(4), 2(7) and 51.

${ }^{226}$ Author's notes from PrepCom Day 1, afternoon session; Delegation of Israel, "Statement made by Israel at the Preparatory Committee for the United Nations Conference on the Arms Trade Treaty"; United Nations General Assembly, Towards an Arms Trade Treaty: Establishing Common International Standards for the Import, Export and Transfer of Conventional Arms., 82.

${ }^{227}$ Aly, "Facilitator's Summary on Implementation and Application," 2; Charles, "Facilitator's Summary for Scope," 5-6; Quinlan, "Facilitator's Summary on Parameters,” 2.
} 
Treaty which the earlier Chairman's Draft Elements did not. ${ }^{228}$ Ultimately, the side promoting illicit brokering - and national security, preventing terrorism and sanctioning licit brokering - was triumphant, as one of the goals listed was to "Prevent, combat and eradicate the illicit ... brokering of conventional weapons". ${ }^{229}$ Furthermore, a second stated goal is preventing diversion to "unauthorised ... users" which it specifies includes terrorists. ${ }^{230}$ This change provides evidence that powerful states in the United Nations have been able to influence the norm and diffuse it within the ATT discussions. The evolved norm regulating illicit brokering will remain in the ATT, as evidenced by its inclusion in the 'Goals and Objectives' of the 2011 Chairman's Draft Paper. ${ }^{231}$ This move undermined the efforts of NGOs to persuade states to take a more comprehensive approach, and is evidence that while NGOs have been able to influence the inclusion of items for negotiation at Treaty discussion, they have little power to ensure they are retained against the influence of more powerful states and stronger norms.

A small group of have tried to prevent the norm regulating brokering being included in the ATT at all, owing to their concerns about national security, nonintervention and being able to continue legal brokering. The UN General Assembly discussed brokering for some time, and subsequently passed Resolution 65/75 on illicit brokering in December 2010. ${ }^{232}$ This resolution relates to all conventional weapons, and is what states meant when referring to a 'future international

\footnotetext{
${ }^{228}$ Moritán, “Chairman's Draft Elements"; Moritán, “Chairman’s Draft Paper - 22 July 2010.”

${ }^{229}$ Moritán, “Chairman’s Draft Paper - 22 July 2010.” Emphasis added.

${ }^{230}$ Ibid.

${ }^{231}$ Moritán, “Chairman’s Draft Paper - 3 March 2010 [sic].”

${ }^{232}$ United Nations General Assembly, Preventing and Combatting Illicit Brokering Activities.
} 
instrument on brokering' separate to the ATT ${ }^{233}$, or stating that "internal transfers" were not within the scope of the ATT. ${ }^{234}$ While some states explain that this is because it is under discussion elsewhere, other nations point to the fact that states are the predominant conventional weapons purchasers and suppliers, making international mechanisms on this tantamount to intervention. ${ }^{235}$

\section{Conclusions}

States have been successful in having the norm regulating brokering included in the ATT, albeit in a revised form, with the retention of the evolved norm regulating illicit brokering in the final outcome documents of the first PrepCom and the second PrepCom. ${ }^{236}$ The Arms Trade Treaty includes the regulation of brokering norm - including regulation of brokers, their actions and sanctions to engender compliance - but the discussions at the first PrepCom highlighted a split in how states perceive the norm. The majority of states accept the norm as is, with a focus on human security and regulating against 'irresponsible' transfers. However key states, including the US, Russia, China and members of the European Union, have successfully promoted a development of the norm towards illicit brokering, to align

\footnotetext{
${ }^{233}$ United Nations General Assembly, Towards an Arms Trade Treaty: Establishing Common International Standards for the Import, Export and Transfer of Conventional Arms., 16, 90, 177.

${ }^{234}$ Author's notes from PrepCom Day 1, afternoon session; Author's notes from PrepCom Day 2, morning session; Author's notes from PrepCom Day 2, afternoon session; Author's notes from PrepCom Day 3, morning session; Author's notes from PrepCom Day 3, afternoon session; Author's notes from PrepCom Day 4, morning session; Programme of Action - Implementation Support System, "Statements - Member States"; United Nations General Assembly, Towards an Arms Trade Treaty: Establishing Common International Standards for the Import, Export and Transfer of Conventional Arms.; International Peace Institute and Wulf, Task Force One: Transnational Security Challenges - Small Arms \& Light Weapons. Non-Paper for Opening Plenary Meeting.

${ }^{235}$ Akram, "Statement by Ambassador Zamir Akram, Permanent Representative of Pakistan to the United Nations, Geneva, in the First Committee"; Graduate Institute of International and Development Studies, Small Arms Survey 2010: Gangs, Groups, and Guns, chap. 1; Vasiliev, "Statement by Mr Victor Vasiliev, Alternate Head of the Russian Delegation to the First Committee of the 64th Session of the UN General Assembly. Explanation of Vote on the Draft Resolution L.38 'Towards an Arms Trade Treaty: Establishing Common International Standards for the Import, Export and Transfer of Conventional Arms'."

${ }^{236}$ Moritán, "Chairman's Draft Paper - 3 March 2010 [sic]”; Moritán, "Chairman’s Draft Paper - 22 July 2010."
} 
with concerns about terrorism, national security and non-intervention. These powerful states have been able to diffuse the altered norm to other states at the ATT PrepCom. The debate resulted in support for a revised, limited norm regulating brokering, which focuses on illicit brokering rather than all brokering. Two conclusions can be drawn from these debates. First, it is clear that measures to address illicit brokering will remain within the Arms Trade Treaty norm cluster. Second, it is equally clear that NGOs only have limited power as norm entrepreneurs in the face of more powerful states and their preference for measures which privilege national security and non-intervention. 


\section{Chapter Five - Non-State Actors and the Arms Trade Treaty}

\section{Introduction}

Over the last decade, the issue of controlling access to weapons by terrorists, insurgents and non-state armed groups has become a common fixture on the agenda of international institutions. This chapter addresses attempts to create a norm regulating the acquisition of small arms and light weapons by these non-state actors, specifically looking at efforts to include the norm in the Arms Trade Treaty. A few states interpreted the norm regulating transfers to non-state actors in a broad way, preventing weapons transfers to all NSAs, but other states believe that NSAs have a role to play in international politics and took a more discriminatory approach to the norm. The chapter begins by defining what is meant by non-state actors, and how controlling their access to weapons came to be an international issue. It will then briefly analyse the norm as it emerged outside of the ATT, before moving on to assessing how it has been debated and contested within the ATT norm cluster.

\section{Non-State Actor Acquisition of Small Arms and Light Weapons}

There are a multiplicity of actors other than states active in international politics, so it is important to clarify from the outset what this thesis defines as a 'nonstate actor' in the context of small arms controls. ${ }^{237}$ Parker does not specifically define the term, but separates those actors which are not states into "criminal groups, terrorists [and] unauthorised non-state actors". ${ }^{238}$ The Biting the Bullet Project notes that non-state actors range from these more common definitions through to private

\footnotetext{
${ }^{237}$ Non-state actors may also be referred to by their common acronym NSAs.

${ }^{238}$ Parker, Analysis of States' Views on an Arms Trade Treaty, 10.
} 
security companies and civilians. ${ }^{239}$ In their ATT submissions, a number of states refer to terrorists or to organised criminal groups, while only a few use the term 'non-state actors' explicitly. In their seminal work on armed groups and human rights, Petrasek and Mann define non-state actors as "groups that are armed, use force to achieve their objectives and are not under state control"' ${ }^{240}$ This definition incorporates the possibility of all three of the groups which Parker separates, and is thus the definition used by this thesis. Its focus is also explicitly on acquisitions by groups, so will not address civilian acquisition of weapons, a topic that is addressed in the next chapter.

\section{Why weapons transfers to non-state actors are problematic}

Non-state actors are increasingly powerful, but states have traditionally been defined as those with a monopoly on the use of force. This has created tension between the two because this right to use force has been a source of state legitimacy for hundreds of years and increasingly common use of force by NSAs challenges this. In some cases, armed non-state actors represent a real threat to the continued existence of a state and to its ability to function, as well as to civilians. For states with NSAs within their borders, there is the potential for NSAs to take action against the state but also for competition between NSAs, such as gangs or tribes, to cause serious and destabilising conflict. ${ }^{241}$ While less common, states have been known to arm resident non-state actors, for example to use against other NSAs which no

\footnotetext{
${ }^{239}$ Greene, Watson, and Kirkham, Developing International Norms to Restrict SALW Transfers to Non-State Actors.

${ }^{240}$ Petrasek and Mann, Ends and Means: Human Rights Approaches to Armed Groups, 5. Italics in original removed.

${ }^{241}$ Graduate Institute of International and Development Studies, Small Arms Survey 2010: Gangs, Groups, and Guns, chap. 3, 10; Greene, Watson, and Kirkham, Developing International Norms to Restrict SALW Transfers to Non-State Actors; Moir, The Law of Internal Armed Conflict; Policzer and Yankey-Wayne, Armed Groups and the Arms Trade Treaty: Challenges and Opportunities.
} 
longer support the state. Non-state actors may also engage in conflict with opponents in another state. ${ }^{242}$ Critics point to the fact that NSAs are not accountable to any authority and are not bound by the same laws of war that states are, with instances where they have put civilians' lives at risk, violated human rights and undermined economic development. ${ }^{243}$ However, some states believe that NSAs have a function in international politics, for example to challenge a repressive state or a state which is believed to be no longer accountable to its citizens. In these cases, supportive states have been known to supply weapons to non-state actors, either in another country or in their own country, to enable their cause. ${ }^{244}$

States are overwhelmingly the dominant purchasers of conventional weapons in the licit market, particularly because many are large and expensive items such as tanks and helicopters. For non-state actors, small arms and light weapons are far more important: they are accessible because they are cheap and easily transported, although the export of conventional weapons is monitored by the states in which they are produced. ${ }^{245}$ Such scrutiny has forced NSAs to turn to the illicit market (or to supportive states) to procure these items which are then used in the commission of crimes, to violate human rights or to kill. To prevent this from occurring, a norm against transfers of small arms to NSAs has begun to emerge.

\footnotetext{
${ }^{242}$ Moir, The Law of Internal Armed Conflict, 2.

${ }^{243}$ There are some who argue that NSAs are bound by laws of war, see Moir, The Law of Internal Armed Conflict.

${ }^{244}$ Butler and Mitchell, "Non-State Actors, States, and Repression: The Effect of Militias and Informal Armed Groups on Human Rights Violations"; Cornish, Arms Trade Treaty - Building Consensus and Making it Work; Garcia, Small Arms and Security: New Emerging International Norms, 177; Graduate Institute of International and Development Studies, Small Arms Survey 2002: Counting the Human Cost, chap. 3; Graduate Institute of International and Development Studies, Small Arms Survey 2010: Gangs, Groups, and Guns, chap. 10; Petrasek and Mann, Ends and Means: Human Rights Approaches to Armed Groups; Policzer and Yankey-Wayne, Armed Groups and the Arms Trade Treaty: Challenges and Opportunities; Shapiro, "Briefing on Pending Major Arms Sale."

${ }^{245}$ Garcia, "Norm Building in the Evolution of the Control of Small Arms in the International Agenda.".
} 


\section{The development of the norm against SALW transfers to non-state actors}

The norm against transfers of small arms and light weapons to non-state actors consists of a presumption that states will deny SALW transfers to non-state actors, a mechanism to regulate transfers and to determine breaches of the law, and a sanctioning mechanism. ${ }^{246}$ Many states are concerned about the implications of any international controls on the transfer of arms, and the controversial debate at the international level about who is and is not authorised to have access to weapons. ${ }^{247}$ Garcia describes this norm as one which has failed to emerge due to this controversy, despite the normative framework of IHL onto which it could be grafted. ${ }^{248}$ In Small Arms and Security, she traces the origins of the norm to a 1998 speech by former Canadian Foreign Minister Lloyd Axworthy ${ }^{249}$, in which he proposed that action to control small arms was necessary and possible (including transfers to NSAs), after which it was taken up by a number of small arms campaigners. ${ }^{250}$ The norm was not well-received by governments at that time, nor during debates at the 2001 Programme of Action Conference, at which the African Group failed to have the norm included in the Programme of Action. ${ }^{251}$ There was recognition among states

\footnotetext{
${ }^{246}$ This norm is taken from the Greene et al. paper on NSAs and Garcia. Garcia, Small Arms and Security: New Emerging International Norms, 178; Greene, Watson, and Kirkham, Developing International Norms to Restrict SALW Transfers to Non-State Actors. As will be seen later, this has the qualifier that potentially, in 'hard cases' or extreme situations, the transfer will not be denied.

${ }^{247}$ United Nations General Assembly, Report of the Group of Governmental Experts to Examine the Feasibility, Scope and Draft Parameters for a Comprehensive, Legally Binding Instrument Establishing Common International Standards for the Import, Export and Transfer of Conventional Arms.

${ }^{248}$ Frey, Progress Report of Barbara Frey, Special Rapporteur on the Prevention of Human Rights Violations Committed with Small Arms and Light Weapons; Garcia, Small Arms and Security: New Emerging International Norms, 178-179; Moir, The Law of Internal Armed Conflict. While this is true, the inclusion of international humanitarian law and human rights law in the ATT remain controversial.

${ }^{249}$ Garcia, Small Arms and Security: New Emerging International Norms, 178, 183-4; Lumpe, "Curbing the Proliferation of Small Arms and Light Weapons."

${ }^{250}$ Garcia, Small Arms and Security: New Emerging International Norms, 183-184.

${ }^{251}$ Ibid., 186-187.
} 
that it was a controversial norm and that it would be difficult to implement. It took the efforts of the Biting the Bullet Project, which specifically took up the development of this norm as a project outside of official fora to garner widespread attention. ${ }^{252}$ Biting the Bullet established the Consultative Group Process (CGP) as a forum for experts to identify "shared understandings and ways forward" relating to preventing weapons transfers to NSAs. ${ }^{253}$ Their paper on the development of a norm against transfers of arms to non-state actors was issued in advance of the 2006 Programme of Action Review Conference, to prompt discussion and to clarify the content and scope of the norm. ${ }^{254}$ In a report following the PrepCom for the 2006 Review Conference, it was noted that several states wanted the issue to be debated, but that the US continued to oppose any discussion on NSAs in this context. ${ }^{255}$ This notwithstanding, references to SALW transfers to non-state actors have continued to be made at more recent Programme of Action conferences. ${ }^{256}$

\footnotetext{
${ }^{252}$ Biting the Bullet Project, Reviewing Action on Small Arms 2006: Assessing the First Five Years of the UN Programme of Action.

${ }^{253}$ Greene, Watson, and Kirkham, Developing International Norms to Restrict SALW Transfers to Non-State Actors, 1. See also Biting the Bullet Project, Reviewing Action on Small Arms 2006: Assessing the First Five Years of the UN Programme of Action, 179; Garcia, Small Arms and Security: New Emerging International Norms, 189.
}

${ }^{254}$ Greene, Watson, and Kirkham, Developing International Norms to Restrict SALW Transfers to Non-State Actors.

${ }^{255}$ Marsh et al., "Overview of Governmental Statements Made at the Small Arms PrepCom.”

${ }^{256}$ Cabactulan, "Philippine Intervention on Agenda Item 7, Consideration of the implementation of the Programme of Action in all its aspects at the national, regional and global levels, including: a) The establishment, where appropriate, of regional and sub-regional mechanisms with a view to preventing, combating, and eradicating the illicit trade in small arms and light weapons across borders, including trans-border customs cooperation and networks for information-sharing among law enforcement, border and customs control agencies"; Degia, "Intervention by Mr. Mohammed Iqbal Degia, First Secretary, Permanent Mission of Barbados to the United Nations on behalf of CARICOM, on the theme of Other issues, and identification of priority issues or topics of relevance in the illicit trade in small arms and light weapons in all its aspects and of their implementation challenges and opportunities"; Delegation of Indonesia, "Statement by Indonesia on 'Other Issues"; Delegation of the Russian Federation, "Proposals for the Inclusion into the Final Document of the Third Biannual Meeting of States to Consider the Implementation of the UN Programme of Action"; Quintero, "Statement by Mrs Nohra Quintero, Coordinator on Disarmament and International Security, Ministry of Foreign Affairs, Colombia: 'Other Matters"; United Nations General Assembly, Report of the Third Biennial Meeting of States to Consider the Implementation of the Programme of Action to Prevent, Combat and Eradicate the Illicit Trade in Small Arms and Light Weapons in All Its Aspects. 
Writing in 2003, Garcia noted that very few international and regional instruments on SALW control included prevention of transfers to NSAs. ${ }^{257}$ Since that time, only the Wassenaar Arrangement's Elements for Export Control of MANPADS, the Asia-Pacific Economic Community's Bangkok Declaration on Partnership for the Future ${ }^{258}$ and the ECOWAS Convention have explicitly stated that non-state actors are to be denied the ability to purchase SALW. ${ }^{259}$ These statements reflect an on-going concern about the dangers of allowing NSAs to have access to small arms, but the fact that they are rare exceptions to the rule also raises serious doubts about the acceptance and influence of this norm.

\section{The norm against SALW transfers to non-state actors in the Arms Trade Treaty}

In the ATT context, the norm against small arms transfers to non-state actors has been referred to on several occasions, despite overall low levels of support for it since its inception. When states responded to Resolution $61 / 89^{260}$, spoke at a series of workshops on the Arms Trade Treaty ${ }^{261}$ and addressed the first PrepCom ${ }^{262}$, several

\footnotetext{
${ }^{257}$ Garcia, Small Arms and Security: New Emerging International Norms, 185.

${ }^{258}$ Hereafter this instrument will be referred to as the Bangkok Declaration and the Asia-Pacific Economic Community by its acronym APEC.

${ }^{259}$ Asia-Pacific Economic Community, Bangkok Declaration on Partnership for the Future; Economic Community of West African States (ECOWAS), ECOWAS Convention on Small Arms and Light Weapons, Their Ammunition and Other Related Materials; Wassenaar Arrangement Secretariat, The Wassenaar Arrangement on Export Controls for Conventional Arms and Dual-Use Goods and Technologies. Basic Documents.

${ }^{260}$ United Nations General Assembly, Towards an Arms Trade Treaty: Establishing Common International Standards for the Import, Export and Transfer of Conventional Arms.; United Nations General Assembly, Towards an Arms Trade Treaty: Establishing Common International Standards for the Import, Export and Transfer of Conventional Arms.; United Nations General Assembly, Towards an Arms Trade Treaty: Establishing Common International Standards for the Import, Export and Transfer of Conventional Arms. (Addendum); United Nations General Assembly, Towards an Arms Trade Treaty: Establishing Common International Standards for the Import, Export and Transfer of Conventional Arms. (Addendum); United Nations General Assembly, Towards an Arms Trade Treaty: Establishing Common International Standards for the Import, Export and Transfer of Conventional Arms. (Addendum).

${ }^{261}$ United Nations Institute for Disarmament Research (UNIDIR) and European Union, "Promoting Discussion on an Arms Trade Treaty - European Union-UNIDIR Project Regional Seminar for Countries in Central, Northern and Western Africa. Summary Report"; United Nations Institute for
} 
mentioned non-state actors specifically. During the first PrepCom, chair Ambassador

Moritán released several draft papers on the topics raised. One of these, the

Chairman's Draft Principles, released on July 14, noted that a possible principle

could be

Reaffirming that the transfer of conventional arms, including small arms and light weapons, must be expressly authorised by competent government authorities as well as a clear prohibition of transfers to unauthorised non-state actors... ${ }^{263}$

This document was obviously influenced by statements from those states which

support the interpretation of the norm that prevents access to SALW by NSAs, such

as the African Group, Norway, and Brazil. ${ }^{264}$ However Iran and Syria objected to

Disarmament Research (UNIDIR) and European Union, "Promoting Discussion on an Arms Trade Treaty - European Union-UNIDIR Project Regional Seminar for Countries in Eastern and Southern Africa. Summary Report"; United Nations Institute for Disarmament Research (UNIDIR) and European Union, "Promoting Discussion on an Arms Trade Treaty - European Union-UNIDIR Project Regional Seminar for Countries in the Americas and the Caribbean. Summary Report"; United Nations Institute for Disarmament Research (UNIDIR) and European Union, "Promoting Discussion on an Arms Trade Treaty - European Union-UNIDIR Project Regional Seminar for Countries in the Middle East. Summary Report"; United Nations Institute for Disarmament Research (UNIDIR) and European Union, "Promoting Discussion on an Arms Trade Treaty - European Union-UNIDIR Project Regional Seminar for Wider Europe. Summary Report."

${ }^{262}$ Author's notes from PrepCom Day 1, afternoon session; Author's notes from PrepCom Day 2, morning session; Author's notes from PrepCom Day 2, afternoon session; Author's notes from PrepCom Day 3, morning session; Author's notes from PrepCom Day 3, afternoon session; Author's notes from PrepCom Day 4, morning session; Abelson, "Statement by Ms. Annette Abelson, Head of Delegation, Norway"; Chabi, "Statement by the Kingdom of Morocco by M. Amine Chabi, First Counsellor, Prepcom of the ATT"; Chabi, "Statement of the Kingdom of Morocco on the Principles of a Future ATT, by M. Amine Chabi, First Counsellor, Prepcom of the ATT"; Delegation of Brazil, "Brazil: Statement on an Arms Trade Treaty"; Delegation of Israel, "Statement made by Israel at the Preparatory Committee for the United Nations Conference on the Arms Trade Treaty"; Delegation of the Russian Federation, "Elements to be Discussed in the Context of a Potential ATT. Introductory Remarks by the Delegation of the Russian Federation"; Delegation of Uruguay, "Presentation of the Uruguay Delegation: Preparatory Committee ATT, 12th to 23rd of July 2010"; Lahai, "Statement made on the Occasion of the Preparatory Committee Meeting for the United Nations Conference on the Arms Trade Treaty, Frist Session, 12-23 July, 2010, by Hon Dr Bernadette Lahai (Chair, Parliamentarians for Global Action, Sierra Leone Chapter)"; Momen, "Statement by Dr A.K. Abdul Momen, Permanent Representative of Bangladesh to the United Nations.".

${ }^{263}$ Moritán, "Chairman's Draft Principles." Emphasis added.

${ }^{264}$ Author's notes from PrepCom Day 1, afternoon session; Author's notes from PrepCom Day 2, morning session; Author's notes from PrepCom Day 2, afternoon session; Author's notes from PrepCom Day 3, morning session; Author's notes from PrepCom Day 4, morning session; Abelson, "Statement by Ms. Annette Abelson, Head of Delegation, Norway"; Biting the Bullet Project, Reviewing Action on Small Arms 2006: Assessing the First Five Years of the UN Programme of Action; Delegation of the Russian Federation, "Elements to be Discussed in the Context of a Potential ATT. Introductory Remarks by the Delegation of the Russian Federation"; Momen, "Statement by Dr 
specifically to this clause on non-state actors ${ }^{265}$, and the Philippines, Pakistan and Nigeria noted their objections to the general subject. ${ }^{266}$ In light of this, the paragraph was deleted, meaning that no mention of non-state actors appeared in the final outcome document of the first PrepCom, the 2010 Chairman's Draft Paper, although there is a watered-down reference to "unauthorised ... users" in the goals and objectives. ${ }^{267}$ It also disappears completely after the second PrepCom. ${ }^{268}$ What factors explain the absence of this nascent norm from the ATT?

\section{Preventing diversion of weapons to non-state actors}

Two clear themes emerged from early discussions about the norm: preventing diversion to NSAs and differentiating between authorised and unauthorised non-state actors.

The goal of preventing the diversion of small arms transfers to non-state actors was raised by numerous states at the PrepCom ${ }^{269}$, and had been raised in a number of fora prior to

A.K. Abdul Momen, Permanent Representative of Bangladesh to the United Nations"; Parker, Analysis of States' Views on an Arms Trade Treaty; Parker, Implications of States' Views on an Arms Trade Treaty; United Nations General Assembly, Towards an Arms Trade Treaty: Establishing Common International Standards for the Import, Export and Transfer of Conventional Arms.; United Nations General Assembly, Towards an Arms Trade Treaty: Establishing Common International Standards for the Import, Export and Transfer of Conventional Arms.; United Nations General Assembly, Towards an Arms Trade Treaty: Establishing Common International Standards for the Import, Export and Transfer of Conventional Arms. (Addendum); United Nations General Assembly, Towards an Arms Trade Treaty: Establishing Common International Standards for the Import, Export and Transfer of Conventional Arms. (Addendum).

${ }^{265}$ Author's notes from PrepCom Day 4, morning session. In addition New Zealand and Israel commented on language used in this clause. Author's notes from PrepCom Day 4, morning session.

${ }^{266}$ Author's notes from PrepCom Day 3, afternoon session; Author's notes from PrepCom Day 4, morning session.

${ }^{267}$ Moritán, "Chairman's Draft Paper - 22 July 2010."

${ }^{268}$ Moritán, "Chairman's Draft Paper - 3 March 2010 [sic]."

${ }^{269}$ Many states are likely to support the prevention of diversion given the number of states that mentioned it in their submissions on the ATT, however only a limited number specifically referred to preventing diversion to NSAs. Abelson, "Statement by Ms. Annette Abelson, Head of Delegation, Norway"; Argentina et al., "Joint Statement on Elements for a Treaty"; Delegation of the Russian Federation, "Elements to be Discussed in the Context of a Potential ATT. Introductory Remarks by the Delegation of the Russian Federation"; Obisakin, "Statement of the African Group delivered by Lawrence Olufemi Obisakin, Minister, Permanent Mission of Nigeria to the UN, at the First Session of the Preparatory Committee for the United Nations Conference on the Arms Trade Treaty"; 
that ${ }^{270}$ States noted with concern the fact that diversion from licit stocks is often how armed groups acquire weapons. ${ }^{271}$ Of the 39 states that mentioned diversion in their submissions to Resolution 61/89, four specifically raised the issue of preventing diversion to "non-state actors". ${ }^{272}$ Other states referred to the need to prevent weapons being diverted to "proscribed groups" such as terrorists or criminals, some mentioned preventing diversion to the illicit market or "unauthorised" users, while the remainder were concerned about diversion more generally. Preventing diversion to NSAs is the broadest interpretation of the norm regulating transfers these groups in the ATT, as it precludes all non-state actors from access to weapons. PrepCom chair Ambassador Moritán included prevention of diversion in two separate paragraphs in his Chairman's Draft Principles but noted, in relation to his earlier Chairman's Draft Elements, that he believed that it would be covered by addressing

Petlyakov, "Regarding the Aims and Purposes of an International Arms Trade Treaty. Statement by Sergey Y Petlyakov (Russian Federation)"; United Nations General Assembly, Towards an Arms Trade Treaty: Establishing Common International Standards for the Import, Export and Transfer of Conventional Arms.; United Nations General Assembly, Towards an Arms Trade Treaty: Establishing Common International Standards for the Import, Export and Transfer of Conventional Arms. (Addendum).

${ }^{270}$ See for example Biting the Bullet Project, Reviewing Action on Small Arms 2006: Assessing the First Five Years of the UN Programme of Action; Greene, Watson, and Kirkham, Developing International Norms to Restrict SALW Transfers to Non-State Actors; United Nations Department for Disarmament Affairs, "Programme of Action to Prevent, Combat and Eradicate the Illicit Trade in Small Arms and Light Weapons in All Its Aspects"; United Nations General Assembly, General and Complete Disarmament: Small Arms. Report of the Group of Governmental Experts on Small Arms; United Nations General Assembly, Protocol against the Illicit Manufacturing of and Trafficking in Firearms, Their Parts and Components and Ammunition, supplementing the United Nations; United Nations General Assembly, "Report of the Open-Ended Working Group towards an Arms Trade Treaty: Establishing Common International Standards for the Import, Export and Transfer of Conventional Arms."

${ }^{271}$ United Nations General Assembly, Towards an Arms Trade Treaty: Establishing Common International Standards for the Import, Export and Transfer of Conventional Arms.

${ }^{272}$ United Nations General Assembly, Towards an Arms Trade Treaty: Establishing Common International Standards for the Import, Export and Transfer of Conventional Arms.; United Nations General Assembly, Towards an Arms Trade Treaty: Establishing Common International Standards for the Import, Export and Transfer of Conventional Arms.; United Nations General Assembly, Towards an Arms Trade Treaty: Establishing Common International Standards for the Import, Export and Transfer of Conventional Arms. (Addendum). 
other concerns. ${ }^{273}$ Both closed sessions on Implementation and Application and Parameters discussed preventing transfers to non-state actors by way of diversion using regulation mechanisms and enforcement. ${ }^{274}$ The final outcome document of the first PrepCom retained the mention of preventing diversion in two 'principles' to be included in the Treaty and, in addition, one principle was moved to a higher position in the document. ${ }^{275}$ The prevention of diversion was clearly stated as a principle of the ATT in the outcome document of the second PrepCom. ${ }^{276}$

States are concerned about diversion to NSAs, because of violence and human rights abuses enabled by access to weapons. ${ }^{277}$ Army and police stockpiles are known to be an important source for the diversion of weapons to the illicit market, and this is where many NSAs obtain their arsenals. ${ }^{278}$ This can be for a variety of reasons, including a lack of secure storage facilities or corruption amongst security force personnel. Several states have made an effort to build their stockpile security, in consideration of this, which shows that they are concerned about inadvertent transfers to NSAs. ${ }^{279}$ Various states believe that the Arms Trade Treaty should

${ }^{273}$ Author's notes from PrepCom Day 2, afternoon session; Moritán, "Chairman's Draft Elements"; Moritán, "Chairman's Draft Principles," 12, 13.

${ }^{274}$ Moritán, “Chairman's Draft Paper - 22 July 2010”; Quinlan, "Facilitator’s Summary on Parameters."

${ }^{275}$ Moritán, “Chairman's Draft Paper - 22 July 2010.” The positioning of clauses in United Nations resolutions is considered a reflection of their respective importance.

${ }^{276}$ Moritán, "Chairman's Draft Paper - 3 March 2010 [sic]."

${ }^{277}$ United Nations General Assembly, Report of the Group of Governmental Experts to Examine the Feasibility, Scope and Draft Parameters for a Comprehensive, Legally Binding Instrument Establishing Common International Standards for the Import, Export and Transfer of Conventional Arms; Biting the Bullet Project, Reviewing Action on Small Arms 2006: Assessing the First Five Years of the UN Programme of Action; Parker, Implications of States' Views on an Arms Trade Treaty; Parker, Analysis of States' Views on an Arms Trade Treaty.

${ }^{278}$ Capie, "Armed Groups, Weapons Availability and Misuse: An Overview of the Issues and Options for Action. Background Paper for a Meeting Organized by the Centre for Humanitarian Dialogue"; Policzer and Yankey-Wayne, Armed Groups and the Arms Trade Treaty: Challenges and Opportunities.

${ }^{279}$ Biting the Bullet Project, Reviewing Action on Small Arms 2006: Assessing the First Five Years of the UN Programme of Action, 190-194. States can be reluctant to admit that they have poor security 
incorporate a control mechanism to prevent transfers to non-state actors via diversion because they fear that their power would be challenged by allowing such transfers. On the other hand, India agrees that diversion to non-state actors is inappropriate, but denies that new legal mechanisms are needed; instead claiming that it is the failure to effectively implement current laws that allows weapons to enter the illicit market and get into the hands of NSAs. ${ }^{280}$ This development of the norm towards preventing diversion of weapons to NSAs is also voiced by those states that have issues with stockpile security but want additional assistance to combat this. States want to continue trading weapons, while avoiding accusations of allowing NSAs access to weapons. ${ }^{281}$ The norm regulating weapons transfers to NSAs has evolved towards preventing diversion to these actors, and this form of the norm is being diffused in the ATT context. This includes the majority of states recognising it, and is thus a strong and positive direction for the norm to take in order to continue within the Treaty norm cluster, because it represents some acceptance by states that not all transfers of weapons to NSAs are useful.

of their armouries, or to reveal information about their armouries at all, as force capability is a traditionally opaque area of state policy.

${ }^{280}$ United Nations General Assembly, Towards an Arms Trade Treaty: Establishing Common International Standards for the Import, Export and Transfer of Conventional Arms., 98-100.

${ }^{281}$ Author's notes from PrepCom Day 1, afternoon session; Author's notes from PrepCom Day 2, morning session; Author's notes from PrepCom Day 2, afternoon session; Author's notes from PrepCom Day 3, morning session; Author's notes from PrepCom Day 3, afternoon session; Author's notes from PrepCom Day 4, morning session; Author's notes from PrepCom Day 5, morning session; Daniel, "Statement Delivered at the Open-Ended Working Group towards an Arms Trade Treaty (Concluding Session - March 6, 2009). Delivered by Mr Lennox A Daniel, Deputy Permanent Representative, Permanent Mission of Saint Vincent and the Grenadines to the United Nations"; Delegation of Turkey, "Statement by the Delegation of Turkey at the First Meeting of the OpenEnded Working Group on Arms Trade Treaty"; United Nations General Assembly, Towards an Arms Trade Treaty: Establishing Common International Standards for the Import, Export and Transfer of Conventional Arms.; United Nations General Assembly, Towards an Arms Trade Treaty: Establishing Common International Standards for the Import, Export and Transfer of Conventional Arms.; United Nations General Assembly, Towards an Arms Trade Treaty: Establishing Common International Standards for the Import, Export and Transfer of Conventional Arms. (Addendum). 
The prevention of terrorism has been listed as a concern by a number of states in their reporting on the potential for an ATT $^{282}$, and in official Treaty settings. ${ }^{283}$ States continually referred to terrorism and most advocated an ATT that included preventing the acquisition of conventional weapons by terrorists. ${ }^{284}$ No state wants to be accused of facilitating terrorism or aiding terrorists. Florquin and Warner point to the $9 / 11$ terror attacks in the United States as a turning point for the debate on NSAs, when states rejected further engagement with them and moved towards classifying all armed non-state actors as 'terrorists'. ${ }^{285}$ Such a classification has important connotations due to the post-9/11 anti-terrorism regime under the auspices of the UN Security Council's Counter-Terrorism Committee and Resolutions 1269,

\begin{abstract}
${ }^{282}$ United Nations General Assembly, Towards an Arms Trade Treaty: Establishing Common International Standards for the Import, Export and Transfer of Conventional Arms.; United Nations General Assembly, Towards an Arms Trade Treaty: Establishing Common International Standards for the Import, Export and Transfer of Conventional Arms.; United Nations General Assembly, Towards an Arms Trade Treaty: Establishing Common International Standards for the Import, Export and Transfer of Conventional Arms. (Addendum); United Nations General Assembly, Towards an Arms Trade Treaty: Establishing Common International Standards for the Import, Export and Transfer of Conventional Arms. (Addendum); United Nations General Assembly, Towards an Arms Trade Treaty: Establishing Common International Standards for the Import, Export and Transfer of Conventional Arms. (Addendum).
\end{abstract}

${ }^{283}$ Author's notes from PrepCom Day 1, afternoon session; Author's notes from PrepCom Day 2, morning session; Author's notes from PrepCom Day 2, afternoon session; Author's notes from PrepCom Day 3, morning session; Author's notes from PrepCom Day 3, afternoon session; Author's notes from PrepCom Day 4, morning session; Author's notes from PrepCom Day 5, morning session; Abelson, "Statement by Ms. Annette Abelson, Head of Delegation, Norway"; Argentina et al., "Joint Statement on Elements for a Treaty"; Delegation of the Russian Federation, "Elements to be Discussed in the Context of a Potential ATT. Introductory Remarks by the Delegation of the Russian Federation"; Delegation of Uruguay, "Presentation of the Uruguay Delegation: Preparatory Committee ATT, 12th to 23rd of July 2010"; Momen, "Statement by Dr A.K. Abdul Momen, Permanent Representative of Bangladesh to the United Nations"; Petlyakov, "Regarding the Aims and Purposes of an International Arms Trade Treaty. Statement by Sergey Y Petlyakov (Russian Federation)."

${ }^{284}$ Author's notes from PrepCom Day 1, afternoon session; Author's notes from PrepCom Day 2, morning session; Author's notes from PrepCom Day 2, afternoon session; Author's notes from PrepCom Day 3, morning session; Author's notes from PrepCom Day 3, afternoon session; Author's notes from PrepCom Day 4, morning session; Author's notes from PrepCom Day 5, morning session; Abelson, "Statement by Ms. Annette Abelson, Head of Delegation, Norway"; Delegation of the Russian Federation, "Elements to be Discussed in the Context of a Potential ATT. Introductory Remarks by the Delegation of the Russian Federation"; Higgie, "Statement by Ambassador Dell Higgie, Permanent Representative to the United Nations in Geneva, New Zealand"; Obisakin, "Statement delivered by Lawrence Olufemi Obisakin, Minister, Permanent Mission of Nigeria to the UN."

${ }^{285}$ Florquin and Warner, "Engaging Non-State Armed Groups or Listing Terrorists? Implications for the Arms Control Community." 
1373 and $1540 .{ }^{286}$ After 2001, states began to increase their ratification and compliance with these international legal instruments to ensure compliance with the new international counter-terrorism regime. ${ }^{287}$

As the world's most powerful state, the US' influence on these principles is strong and it has taken a hard line on terrorism. Subsequently, counter-terrorism legislation, information sharing and capacity building among other states have increased significantly since the $9 / 11$ attacks. ${ }^{288}$ US views on the ATT were also shaped in this context. US officials describe it as a legal instrument worth participating in because it seeks to prevent transfers of weapons "to rogue states, terrorist groups, and groups seeking to unsettle regions". ${ }^{289}$ This focus on combatting terrorism has been a significant catalyst for international co-operation and a tipping point for the norm regulating transfers to non-state actors, as it evolves towards preventing diversion. The US has the ability to reward or punish states depending on their perceived support (or lack of) for its anti-terrorism agenda. ${ }^{290}$ Aligning the ATT with terrorism prevention both gives precedence to terrorism and reinforces the US position that while some states (and non-state actors) are not considered problematic, and may be supported by direct or indirect diversion of weapons, others are..$^{291}$

${ }^{286}$ United Nations Security Council, United Nations Security Council Resolution 1269; United Nations Security Council, United Nations Security Council Resolution 1373; United Nations Security Council, United Nations Security Council Resolution 1540. Several of these Resolutions draw on the Security Council's powers under Chapter VII of the United Nations Charter, which grants them the ability to require compliance. There are a variety of international and regional anti-terrorism conventions and measures which deal with potential terrorist acts. Ramraj, Hor, and Roach, Global Anti-Terrorism Law and Policy, chap. 11, 12; United Nations, The Charter of the United Nations; United Nations, "Text and Status of the United Nations Conventions on Terrorism."

${ }^{287}$ Ramraj, Hor, and Roach, Global Anti-Terrorism Law and Policy, 7.

${ }^{288}$ Haque, "Government Responses to Terrorism: Critical Views of Their Impacts on People and Public Administration," 172.

${ }^{289}$ Clinton, "U.S. Support for the Arms Trade Treaty." Emphasis added.

${ }^{290}$ Stohl, "Questionable Reward: Arms Sales and the War on Terrorism."

${ }^{291}$ Ostrander, "Changing Direction on Non-Nuclear Arms Control? American Exceptionalism, Power and Constancy," 519. 
This move towards diversion prevention is interesting then, as it refocuses the lens onto national evaluation of who is authorised to have access to SALW and preventing others from access. Linking prevention of diversion to the norm against small arms transfers to NSAs emphasises national discretion in granting authorisation and the primacy of the state in making these decisions, albeit within the bounds of the proposed international law. Such an alignment underscores the fact that while NGOs have got the issue onto the ATT agenda, powerful states are able to frame it into something more acceptable to their concerns about national security, or reject it. This restricts the scope of the norm considerably and shows that promoters of the original norm such as Oxfam and Amnesty International, who continue to press for all actors to be covered by the Treaty, have not been able to convince states to take a comprehensive approach to preventing transfers to NSAs. ${ }^{292}$ They have not been able to mount a successful defence against powerful states promoting other variations of the norm. Instead, powerful states like Russia, the US and the UK support preventing some diversion of weapons to NSAs because they want control over who has access to weapons. ${ }^{293}$ This narrower evolution of the norm has been taken further in the context of Treaty discussions, as will be demonstrated in the next section.

\footnotetext{
${ }^{292}$ Amnesty International, Dead on Time-Arms Transportation, Brokering and the Threat to Human Rights; Amnesty International, Deadly Movements: Arms Transportation Controls in the Arms Trade Treaty; Control Arms Campaign, Arms Without Borders: Why a Globalised Trade Needs Global Controls; Cornish, Arms Trade Treaty - Building Consensus and Making it Work; Greene and Kirkham, Preventing Diversion of Small Arms and Light Weapons: Issues and Priorities for Strengthened Controls.

${ }^{293}$ See the next section for more detail on this. Duncan, "Open-Ended Working Group: Towards an Arms Trade Treaty. Intervention by Ambassador John Duncan, 4 March 2009. Scope of a Potential Arms Trade Treaty"; Petlyakov, "On the Activities of the Open-Ended Working Group (OEWG) to Address the Issues of the International Trade in Conventional Arms. Statement by Sergey Y Petlyakov (Russian Federation)"; Petlyakov, "Regarding the Aims and Purposes of an International Arms Trade Treaty. Statement by Sergey Y Petlyakov (Russian Federation)"; United Nations General Assembly, Towards an Arms Trade Treaty: Establishing Common International Standards for the Import, Export and Transfer of Conventional Arms.
} 


\section{Authorised non-state actors versus unauthorised non-state actors}

The norm preventing weapons transfers to NSAs presumes that states will not transfer small arms to non-state actors. States seek to retain decision-making over what is imported into their states, and unapproved small arms transfers to NSAs represent a genuine danger. Conversely, states that arm non-state actors wish to continue to have this ability, as mentioned above. One example of this occurred around 1980, when the US provided weapons to the mujahedeen in Afghanistan so that they could fight against the Soviets for themselves and for the US, who was engaged in a Cold War with the Soviet nation at the time. ${ }^{294}$ There has also been considerable debate about whether to bar transfers to all non-state armed groups or simply those not deemed to have the proper authority, and how to implement the norm. ${ }^{295}$ The outcome documents from the Arms Trade Treaty PrepCom show this plainly, where the Chairman's Draft Principles paper states that the Treaty should contain "a clear prohibition of transfers to unauthorised non-State actors". ${ }^{296}$ The Facilitator's Summary on Parameters says that states should consider adding measures into the Treaty to prevent transfers where there is a risk of the weapons being transferred to "unauthorised end-users or non-state actors". ${ }^{297}$ However, this distinction is removed from the principles in the 2010 Chairman's Draft Paper and

\footnotetext{
${ }^{294}$ Boutwell and Klare, "A Scourge of Small Arms"; Lumpe, "Curbing the Proliferation of Small Arms and Light Weapons"; Stohl, "Questionable Reward: Arms Sales and the War on Terrorism."

${ }^{295}$ Previously, states have more commonly referred to preventing 'unlawful transfers' to NSAs, see for example Biting the Bullet Project, Reviewing Action on Small Arms 2006: Assessing the First Five Years of the UN Programme of Action; United Nations General Assembly, Report of the Group of Governmental Experts to Examine the Feasibility, Scope and Draft Parameters for a Comprehensive, Legally Binding Instrument Establishing Common International Standards for the Import, Export and Transfer of Conventional Arms.

${ }^{296}$ Moritán, “Chairman’s Draft Principles.” Emphasis added.

${ }^{297}$ Quinlan, "Facilitator's Summary on Parameters."
} 
instead one of the Treaty's goals has become preventing diversion to "unauthorised uses and users". ${ }^{298}$

The change has resulted from a debate about the definition of a non-state actor, but also from state concerns about their national security and sovereignty in a world of intra-state conflict and terrorism. As mentioned earlier, this thesis defines NSAs as armed groups who use force to reach their goals and are not controlled by the state. There are a wide variety of groups which fit this definition ${ }^{299}$, and some have a level of civilian support such as Hezbollah and the Taliban. ${ }^{300}$ In discussing the ATT, states mentioned formalising a definition of NSAs, but there was a mixed reaction to this suggestion because of the varied roles they play and actions they undertake. ${ }^{301}$ There was no agreement on what a non-state actor was, but there was a clear move towards classifying NSAs as either 'good' or 'bad'.

In its response to Resolution 61/89, Brazil distinguished between authorised and "unauthorised non-state actors", the latter of which are prevented from acquiring small arms. ${ }^{302}$ This approach echoes a distinction made in earlier publications by Biting the Bullet and the UN Development Programme, between authorised and unauthorised users of SALW. ${ }^{303}$ Nine other states agreed that the ATT should include controls to prevent transfers to 'unauthorised users'; including New Zealand, which

\footnotetext{
${ }^{298}$ Moritán, “Chairman’s Draft Paper - 22 July 2010.” Emphasis added.

${ }^{299}$ See for example Graduate Institute of International and Development Studies, Small Arms Survey 2010: Gangs, Groups, and Guns, chap. 3, 10.

${ }^{300}$ Johnson and Mason, “All Counterinsurgency Is Local.” Some of these groups have co-opted support from the community by force.

${ }^{301}$ Author's notes from PrepCom Day 2, morning session; Author's notes from PrepCom Day 3, morning session; Author's notes from PrepCom Day 4, morning session.

${ }^{302}$ United Nations General Assembly, Towards an Arms Trade Treaty: Establishing Common International Standards for the Import, Export and Transfer of Conventional Arms., 29.

${ }^{303}$ Greene and Kirkham, Preventing Diversion of Small Arms and Light Weapons: Issues and Priorities for Strengthened Controls, 6; United Nations Development Programme, How to Guide: Small Arms and Light Weapons Legislation.
} 
specified that this included terrorists. ${ }^{304}$ The idea of "non-authorised" non-state actors also arose at a Dakar meeting of states on the ATT. ${ }^{305}$ Brazil continued to promote this distinction between authorised and unauthorised NSAs at the PrepCom ${ }^{306}$ and this was echoed by other states that began to agree that this was an acceptable development with regard to the norm. ${ }^{307}$ Brazil's norm promotion efforts have proved effective because they are also supported by powerful states, such as the EU and the US. ${ }^{308}$ There are some limits to this agreement however, with states not explicitly calling for the prevention of transfers to NSAs; rather some have continued to couch it in terms of preventing transfers to 'unauthorised users'. ${ }^{309}$ Other states did not mention the norm at the PrepCom but their previous statements endorse this position, for example the United States, which made it clear that there were cases in which a non-state actor could have weapons transferred to it, as alluded to earlier. In line with this, the Facilitator's Summary on Parameters and the final outcome documents of the two PrepComs made reference to terrorism. ${ }^{310}$

\footnotetext{
${ }^{304}$ United Nations General Assembly, Towards an Arms Trade Treaty: Establishing Common International Standards for the Import, Export and Transfer of Conventional Arms., 20; United Nations General Assembly, Towards an Arms Trade Treaty: Establishing Common International Standards for the Import, Export and Transfer of Conventional Arms. , 14, 37, 69, 106, 115, 129, 148, 214.

${ }^{305}$ United Nations Institute for Disarmament Research (UNIDIR) and European Union, "Promoting Discussion on an Arms Trade Treaty - European Union-UNIDIR Project Regional Seminar for Countries in Central, Northern and Western Africa. Summary Report."

${ }^{306}$ Delegation of Brazil, "Brazil: Statement on an Arms Trade Treaty."

${ }^{307}$ Author's notes from PrepCom Day 4, morning session; Argentina et al., "Joint Statement on Elements for a Treaty"; Economic Community of West African States (ECOWAS), "Statement by Economic Community of West African States"; Obisakin, "Statement of the African Group delivered by Lawrence Olufemi Obisakin, Minister, Permanent Mission of Nigeria to the UN, at the First Session of the Preparatory Committee for the United Nations Conference on the Arms Trade Treaty."

${ }^{308}$ Stohl, "Questionable Reward: Arms Sales and the War on Terrorism"; Amnesty International, Blood at the Crossroads: Making the Case for a Global Arms Trade Treaty; Amnesty International, Dead on Time - Arms Transportation, Brokering and the Threat to Human Rights.

${ }^{309}$ Greene and Kirkham, Preventing Diversion of Small Arms and Light Weapons: Issues and Priorities for Strengthened Controls; United Nations Development Programme, How to Guide: Small Arms and Light Weapons Legislation.

${ }^{310}$ Bauwens, "Statement by H.E. Mr Werner Bauwens, Special Envoy for Disarmament and NonProliferation, European Union. EU Statement on the Goals and Objectives of an ATT"; Bauwens,
} 
The development of the norm preventing transfers to non-state actors clearly distinguishes between NGOs and governments that want to regulate all transfers (including those between states), and those states that want to control some transfers (namely those to unauthorised non-state actors). As was noted earlier, not all states want an ATT to contain measures that would restrict transfers to NSAs, as they want to be able to (continue to) use these NSAs for their own goals. Some governments also believe that there are occasions when a non-state actor is justified in using force against a state if it is deemed to have become corrupt, repressive or violent against its citizens. ${ }^{311}$ In these situations, it could meet the stringent criteria for a "hard case", which justifies a weapons transfer to a non-state actor. ${ }^{312}$ State transfers of weapons to NSAs have changed the way that states think about non-state actors and their acquisition of weapons, making it more acceptable in the eyes of some states for specific non-state groups and organisations to utilise force in pursuit of their goals. However there is a distinction made between NSAs which are considered acceptable, or considered to have a more legitimate 'cause', and those which are not. In general, the decision over who will become authorised depends on the states and actors, the geopolitics of the situation, the costs and benefits, and the willingness of the state to become involved. It must also be noted that the classification of authorised or unauthorised is not static. These states agree, however, that some NSAs are more 'legitimate' than others and wish to continue transferring weapons to them. This

\footnotetext{
"Statement by H.E. Mr Werner Bauwens, Special Envoy for Disarmament and Non-Proliferation, European Union. EU Statement on the Principles Governing the Arms Trade Treaty"; Moritán, “Chairman's Draft Elements”; Moritán, “Chairman’s Draft Paper - 22 July 2010”; Moritán, "Chairman's Draft Principles"; Quinlan, "Facilitator's Summary on Parameters"; Moritán, "Chairman's Draft Paper - 3 March 2010 [sic]."

${ }^{311}$ Butler and Mitchell, "Non-State Actors, States, and Repression: The Effect of Militias and Informal Armed Groups on Human Rights Violations."

${ }^{312}$ Greene, Watson, and Kirkham, Developing International Norms to Restrict SALW Transfers to Non-State Actors, 5-8.
} 
evolution of the norm allows states the freedom to decide if an actor will be authorised to take action and to transfer weapons to them to carry this out.

A lesser number of voices continued to promote the comprehensive norm, preventing any weapons transfers to NSAs. ${ }^{313}$ There are two types of states that support this version of the norm - those that believe that transfers to NSAs are a threat to human security and those that believe that transfers to NSAs are a threat to national security. These governments are convinced that there can be no 'hard cases' in which a transfer of weapons to non-state actors might be warranted. They warn against arming NSAs because it breaches the right of states to hold a monopoly on the use of force, and principles of territorial integrity and non-intervention. ${ }^{314}$ For example, Bangladesh referred to a Treaty which allows only legal transfers of conventional weapons between states, and went on to exhort that states "should not hand over the imported weapons to any political group or insurgent groups [sic]". ${ }^{315}$ This statement represents a vehement pronouncement of the view of a majority of states, which is that NSAs are a threat to state legitimacy and survival. It is easy to determine why states support this view because in most cases, the governments deciding which NSAs are authorised are external; i.e. another state is choosing to arm a local population against its own government. This breaks one of the most sacred norms of international relations - non-intervention. By diminishing the taboo

\footnotetext{
${ }^{313}$ Author's notes from PrepCom Day 1, afternoon session; Author's notes from PrepCom Day 2, afternoon session; Author's notes from PrepCom Day 3, morning session; Author's notes from PrepCom Day 3, afternoon session; Author's notes from PrepCom Day 4, morning session; United Nations General Assembly, Towards an Arms Trade Treaty: Establishing Common International Standards for the Import, Export and Transfer of Conventional Arms., 55, 128. As mentioned earlier, other states may support the norm without indicating this in their statement.

${ }^{314}$ Author's notes from PrepCom Day 2, afternoon session; Author's notes from PrepCom Day 3, morning session; Chabi, "Statement by the Kingdom of Morocco by M. Amine Chabi, First Counsellor, Prepcom of the ATT"; Chabi, "Statement of the Kingdom of Morocco on the Principles of a Future ATT, by M. Amine Chabi, First Counsellor, Prepcom of the ATT."

${ }^{315}$ Momen, "Statement by Dr A.K. Abdul Momen, Permanent Representative of Bangladesh to the United Nations."
} 
on transfers to NSAs, states undermine the age-old tenet of the state as sole legitimate holder of the monopoly on the use of force and risk weakening state sovereignty through a form of intervention. For this reason, states that vigorously defend the sanctity of sovereignty, like China and Egypt, sought to prevent any weapons transfers to NSAs ${ }^{316}$, despite the fact that in some cases, their practises are inconsistent with their public statements. ${ }^{317}$ Several of these states have experienced armed conflict within their borders involving non-state actors, and their reservations about a Treaty which allows any 'militarisation' of NSAs stem from this. ${ }^{318}$ These actors were able to successfully oppose the emergent development of the norm distinguishing between authorised and unauthorised NSAs, although many of the states that endorse this approach to the norm are not particularly powerful (excepting China and Russia). These states have some power to draw the debate out or weaken the norm, due to the need for consensus in the Treaty process. This in turn gives states that oppose the norm the power to dilute the norm further, because they are able to grind down the resistance of states that prefer a (comprehensive) Treaty being decided. It is also difficult to classify NSAs into 'good' or 'bad' - or in this case authorised and unauthorised - which makes the implementation and enforcement of such a distinction close to impossible, particularly as states are likely to disagree over which groups are 'authorised' and which are not. Therefore, although the 2010 Chairman's Draft Paper replaces the 'non-state actors' with 'users', the term

\footnotetext{
${ }^{316}$ Author's notes from PrepCom Day 1, afternoon session; Author's notes from PrepCom Day 2, afternoon session.; Author's notes from PrepCom Day 3, morning session; Author's notes from PrepCom Day 4, morning session.

${ }^{317}$ Amnesty International, Blood at the Crossroads: Making the Case for a Global Arms Trade Treaty; Amnesty International, Dead on Time - Arms Transportation, Brokering and the Threat to Human Rights; Amnesty International, Deadly Movements: Arms Transportation Controls in the Arms Trade Treaty.

${ }^{318}$ Butler and Mitchell, "Non-State Actors, States, and Repression: The Effect of Militias and Informal Armed Groups on Human Rights Violations."
} 
"unauthorised" has disappeared entirely by the time of the second PrepCom, suggesting that powerful states including Russia and China have been successful at removing this version of the norm. ${ }^{319}$ The difficulty in determining which NSAs are authorised and unauthorised has proven too difficult to regulate.

\section{Conclusions}

The norm preventing transfers of weapons to non-state actors sits precariously within the ATT norm cluster. Few states openly called for its inclusion in the Treaty at the PrepCom in July 2010, reflecting both its complexity and how it has been modified over time. Initially, the norm presumed that states would not transfer weapons to any NSAs and was taken up by some states and organisations in the late 1990s. It made its way into the Arms Trade Treaty discussions through the efforts of the Biting the Bullet campaign, who worked with a small group of likeminded states. Within the context of the ATT debates however, the norm evolved to focus exclusively on preventing diversion to NSAs and distinguishing between two types of NSAs - authorised and unauthorised.

The split between states over whether to allow transfers of SALW to nonstate actors remains, with the majority refraining from comment in an acknowledgement of the complexity and sensitivity of the issue. As the norm continues to evolve towards a narrow focus on preventing diversion of transfers to NSAs however, it stands a better chance of becoming accepted in the ATT, having reached a point where enough states support this evolution to carry it forward. Efforts to promote an approach which would allow transfers to only 'authorised' actors, rather than focusing on non-state actors, has not proved as fruitful because of the difficulty in determining which NSAs are to be authorised, who decides this and

\footnotetext{
${ }^{319}$ Moritán, “Chairman’s Draft Paper - 3 March 2010 [sic].”
} 
how it will be implemented. The opposition of powerful states like China was enough to prevent this approach to the norm from reaching a tipping point and fully emerging. 


\section{Chapter Six - Civilian Possession and the Arms Trade Treaty}

\section{Introduction}

This final chapter explores attempts to diffuse a norm regulating civilian possession of small arms, and include it within the Arms Trade Treaty. This norm predominantly deals with small arms, as light weapons are typically more heavily proscribed within domestic legislation. It has also proved highly controversial in the context of the ATT, as several states and NGOs openly objected to its inclusion. To understand its evolution and current status, this chapter will first describe the norm, before outlining its development prior to the establishment of the ATT process. It then seeks to explain the controversies around regulating civilian ownership, both nationally and internationally. Finally, the chapter will assess how the norm has been incorporated into the cluster of norms in the ATT and will attempt to explain the responses of states to the norm, and the future prospects for the norm in the Treaty norm cluster.

\section{Regulating Civilian Possession of Small Atms}

There are hundreds of millions of small arms in circulation in the world and the majority of these weapons are civilian owned. ${ }^{320}$ Rationales for the state to permit civilian possession of weapons are related to personal self-defence, hunting and sport shooting. Weapons collectors, sport shooters and game hunters alike claim the right to possess a variety of different firearms for recreational and competition sports. ${ }^{321}$ In addition, civilians in the US have the 'right to bear arms' enshrined in the Bill of

\footnotetext{
${ }^{320}$ Greene and Kirkham, Preventing Diversion of Small Arms and Light Weapons: Issues and Priorities for Strengthened Controls, 11.

${ }^{321}$ There is a range of activities such as small-bore competition shooting and clay bird shooting which can be classified as recreational.
} 
Rights. Those who wish to retain access to weapons refer to statistics that show that misuse of weapons is undertaken by 'criminals' with 'illegal' weapons which they have obtained on the 'black market'. Conversely, those wanting tighter regulation of firearms ownership note that most 'illegal' weapons were originally bought legally and have made their way to an unlicensed owner. There is a vast literature about the relationship between weapons availability and incidents of crime and armed violence, but major differences remain among scholars. ${ }^{322}$ This lack of consensus among scholars and analysts has contributed to the heated debate about regulating civilian possession of firearms.

\section{Why civilian possession of small arms needs regulation}

Many of those who own weapons have licences to possess them, are safety conscious and do not on-sell the items to unlicensed persons, but there are others who are not as scrupulous about their behaviour. ${ }^{323}$ Likewise, there are a number of legitimate arms dealers who follow national legislative guidelines and sell within regulatory limits; and there are a number who do not. ${ }^{324}$ These weapons make their way into the hands of those who use them illegally and are often 'recycled' through various owners. According to Garcia

... there is now a general recognition that civilian-owned guns help to fuel the illicit arms trade as a result of theft, unsafe storage or sale. ${ }^{325}$

\footnotetext{
${ }^{322}$ Inevitably, each study highlights a difference aspect of the issue related to small arms misuse, and it is therefore difficult to compare them directly. Some examples of these studies are Duggan, "More Guns, More Crime"; Ludwig and Cook, "Public Policy Perspectives: Principles for Effective Gun Policy"; Richmond, Cheney, and Schwab, "The Global Burden of Non-Conflict Related Firearm Mortality."

${ }^{323}$ Safety conscious means that the owner follows national established best practice for securing weapons in a storage place.

${ }^{324}$ Fallis, "Virginia Gun Store D \& R Arms: Fastest from Counter to Crime."

${ }^{325}$ Garcia, Small Arms and Security: New Emerging International Norms, 160. This fact is debated by individuals and organisations which support the civilian possession of weapons with minimal regulation.
} 
These weapons can go on to become involved in crimes and human rights abuses in the origin state or in another state. ${ }^{326}$ For his reason, some NGOs and concerned states have acted to promote the norm regulating civilian possession of small arms at a global level.

\section{The development of the norm regulating civilian possession of small arms}

The norm consists of three requirements, the first being that states regulate which civilians can possess small arms; the second is a licensing system ${ }^{327}$, and the third being a sanctions mechanism. ${ }^{328}$ The regulation which states put in place nationally works on a basic model, which prevents individuals from possession of small arms if they have committed a (specific) crime, have diminished mental capacity or are under a specified age limit. ${ }^{329}$ The licensing system then verifies that this individual or business can access weapons legitimately or that the weapon is registered to a specific person or business. ${ }^{330}$ Garcia argues that an international norm requiring the regulation of civilian possession of small arms began to emerge around 2006, when states started to recognise that they had a duty to outline the "responsibilities" that citizens possessing weapons must accept, due to their lethal nature. ${ }^{331}$ Previously, even many pro-disarmament NGOs had been reluctant to

\footnotetext{
${ }^{326}$ Cukier et al., Regulation of Civilian Possession of Small Arms and Light Weapons.

${ }^{327}$ This can be a licence for individuals or a firearms registration requirement, both of which need a record keeping system to be established.

${ }^{328}$ These elements are taken from the Programme of Action, Cukier et al. and Garcia Cukier et al., Regulation of Civilian Possession of Small Arms and Light Weapons; Garcia, Small Arms and Security: New Emerging International Norms, 162; United Nations Department for Disarmament Affairs, "Programme of Action to Prevent, Combat and Eradicate the Illicit Trade in Small Arms and Light Weapons in All Its Aspects."

${ }^{329}$ For examples of state policy on civilian possession, see Alpers and Wilson, "Gun Policy: Facts and News."

${ }^{330}$ A business, in this sense, implies arms dealers, security companies or gun ranges for example. It does not include military or police forces, which are typically guided by specific institutional policies owing to the nature of their work.

${ }^{331}$ Garcia, Small Arms and Security: New Emerging International Norms, 161, 163.
} 
incorporate disapproval of civilian holdings of weapons in their disarmament campaigns for "strategic reasons", worrying that it would attract opposition from the well-resourced and powerful gun lobby ${ }^{332}$. Strong advocacy from a minority of 'gunfree' NGOs such as Viva Rio and Gun-Free South Africa created a change in direction amongst NGOs. ${ }^{333}$ The norm's growing profile at the international level can be traced to the UN Commission on Crime Prevention and Criminal Justice and the 1995 UN Economic and Social Council's resolution entitled Firearm Regulation for the Purpose of Crime Prevention and Public Health and Safety, which established the issue on the agenda of the United Nations. ${ }^{334}$ The resulting report from the UN Secretary-General was a collation of the world's firearms regulation which concludes recommendations that states regulate "safe use and storage of firearms", with a variety of licensing and punitive mechanisms to enforce these behaviours. ${ }^{335}$ The UN Commission on Crime Prevention and Criminal Justice played a key role in norm promotion in the early years, as have like-minded governments and NGOs like Viva Rio and Gun-Free South Africa, as they have worked to promote the norm despite opposition from gun lobby groups in a number of states like the US and Canada. ${ }^{336}$

Attempts at norm promotion within states have not been particularly successful despite the efforts of some NGOS. Where gun control advocates are able to successfully graft the norm onto notions of common humanity and dangers to

\footnotetext{
${ }^{332}$ Ibid., 161-162.

333 Ibid.

${ }^{334}$ Ibid., 165; United Nations Economic and Social Council, Firearm Regulation for Purposes of Crime Prevention and Public Health and Safety.

${ }^{335}$ Garcia, Small Arms and Security: New Emerging International Norms, 162; United Nations Economic and Social Council, Criminal Justice Reform and Strengthening of Legal Institutions: Measures to Regulate Firearms (and Annexes), 7-8, Annex II.

${ }^{336}$ Garcia, Small Arms and Security: New Emerging International Norms, 162, 165-167.
} 
public health, they have more success, as they are able link the norm to particular triggers that catalyse public reaction. In terms of the norm promoting regulation of civilian possession key catalytic events are, unfortunately, often deaths. The tragic events that unfolded at Port Arthur, Dunblane and Ecole Polytechnique in the 1990s illustrate three cases where mass killings led to public debate about appropriate legislation on firearms possession. ${ }^{337}$ Such norm promotion needs a strong advocate with a clear message and an organisational platform to build from. The Gun Control Network, formed in the aftermath of Dunblane, was able to lobby the British Government for changes to legislation on handguns, air rifles, and imitation guns; with its efforts particularly evident in the United Kingdom's Violent Crime Reduction Act (2006). ${ }^{338}$ Increasing evidence of criminal activity involving firearms in South Africa has been the target of action by Gun Free South Africa. As well as influencing national legislation, it supported increased enforcement of the Firearms Control Act (2000) and continued to research and advocate on the issue, making South Africa a strong advocate for the ATT. ${ }^{339}$ However the tragic mass-killing which took place at Columbine High School (1999) in the US had little impact on domestic policy, according to Birkland and Lawrence. They attribute this to the way that it was portrayed in the media, and the result of this was that any potential message about regulating civilian possession of weapons was lost amid a wider debate about youth and their behaviour. ${ }^{340}$ This undermined the message about gun control, much to the dismay of anti-gun norm promoters such as the Brady Center to

\footnotetext{
337 "IANSA Director in Gun Debate with the NRA"; Mouzos, Firearm-Related Violence: The Impact of the Nationwide Agreement on Firearms. These tragedies occurred in Australia (1996), Scotland (1996) and Canada (1994) respectively.

${ }^{338}$ Gun Control Network, "Gun Control Network - Home."

${ }^{339}$ Gun Free South Africa, "Gun Free South Africa: About Us."

${ }^{340}$ Birkland and Lawrence, "Media Framing and Policy Change after Columbine." The article mentions the events at Virginia Tech only briefly, owing to the timing of publication.
} 
Prevent Gun Violence, as they were unable to use their organisational platform to generate more support for the norm. ${ }^{341}$

Most regional legislative measures on small arms between 1997 and 2001 did not include any reference to civilian firearms possession, the exceptions being the Bamako Declaration, the Nairobi Declaration and the SADC Protocol. ${ }^{342}$ However since that time, the Andean Plan, the Arab Model Law, the Central American Code of Conduct and the ECOWAS Convention have all included the norm, indicating an increase in regulation of civilian possession. ${ }^{343}$ The ECOWAS Convention prohibits possession of light weapons outright but allows for some civilian possession of small arms. ${ }^{344}$ While many states have agreed to establish laws regulating the possession of small arms by civilians, surveys suggest that its actual implementation has been sporadic. ${ }^{345}$ Even if there has been growing rhetoric around the norm at the regional and international level, it does not seem to be as well diffused as it may first appear, as even states from the regions which endorse the norm have not institutionalised it into a strong position in their own legislation.

As was noted, the nascent norm is notable for its opponents who argue against regulation or stronger regulation of civilian possession of these weapons, asserting that their citizens have a traditional, cultural and or constitutional 'right' to

\footnotetext{
${ }^{341}$ Horwitz and Grimaldi, "NRA-led gun lobby wields powerful influence over ATF, U.S. politics."

${ }^{342}$ Garcia, Small Arms and Security: New Emerging International Norms, 168-169.

${ }^{343}$ Andean Community, Decision 552: Andean Plan to Prevent, Combat and Eradicate Illicit Trade in Small Arms and Light Weapons in all its Aspects (and Annexes); Economic Community of West African States (ECOWAS), ECOWAS Convention on Small Arms and Light Weapons, Their Ammunition and Other Related Materials; Interior Ministers Council League of Arab States (General Secretariat), Arab Model Law on Weapons, Ammunitions, Explosives and Hazardous Material; Nicaragua, "Working Paper Submitted by Nicaragua: Code of Conduct of Central American States on the Transfer of Arms, Ammunition, Explosives and Other Related Materiel (A/CONF.192/2006/RC/WP.6)."

${ }^{344}$ Economic Community of West African States (ECOWAS), ECOWAS Convention on Small Arms and Light Weapons, Their Ammunition and Other Related Materials. Article 14.

${ }^{345}$ Alpers and Wilson, "Gun Policy: Facts and News."
} 
possess weapons. The most prominent of these are Australia, Canada ${ }^{346}$, New Zealand and the United States, whose residents claim the right to own weapons for the purposes of recreational use, or personal self-defence. ${ }^{347}$ Several Middle Eastern states, where there is a high level of civilian weapons possession, are also against tougher regulation of small arms. ${ }^{348}$ Powerful pro-gun NGOs work to ensure that this right is not undermined by regulation, lobbying parliamentarians and officials regarding national and international small arms laws. Most groups are organised on a national basis, but have ties to similar organisations abroad. Most notably, the NRA and its Institute for Legislative Action (NRA-ILA) are active internationally, with the ability to mobilise its members' views on small arms issues. ${ }^{349}$ During the 2001 Programme of Action Conference, the power of the NRA was demonstrated when the United States "harped on its 'redline' items: ... [including] rules on civilian possession (an NRA no-no)" in the conference. ${ }^{350}$ The NRA has been able to hinder the progress of gun regulation in the US and other countries. ${ }^{351}$ It denies allegations that its actions are preventing law enforcement officials the ability to do their job, by promoting weapons availability and possession, claiming that such possession is a deterrent for crime and useful as a self-defence tool. Other pro-gun NGOs that have been active internationally include the World Forum on the Future of Sport Shooting

\footnotetext{
${ }^{346}$ Canada has promoted regulation of civilian possession discussions however. Garcia, Small Arms and Security: New Emerging International Norms, 167.

${ }^{347}$ While the United States is the only state to have the 'right to bear arms' in its Constitution, there are similar legislative protections on the ability to own weapons in the three other states. Alpers and Wilson, "Gun Policy: Facts and News"; Cukier et al., Regulation of Civilian Possession of Small Arms and Light Weapons.

${ }^{348}$ Alpers and Wilson, "Gun Policy: Facts and News"; Capie, "Localization as Resistance: The Contested Diffusion of Small Arms Norms in Southeast Asia," 641.

${ }^{349}$ Hereafter these organisations will be referred to by their acronyms, NRA and NRA-ILA.

${ }^{350}$ Gabelnick and Firchow, "UN Small Arms Conference: Evaluation and Prospects."

${ }^{351}$ Grimaldi and Horwitz, "Industry Pressure Hides Gun Traces, Protects Dealers from Public Scrutiny"; Horwitz and Grimaldi, "ATF's Oversight Limited in Face of Gun Lobby"; LaPierre, "NRA-ILA: Why You Should Care About Brazil."
} 
Activities (WFSA), the International Coalition of Women in Shooting and Hunting

(WiSH), and the Defense Small Arms Advisory Council (DSAAC). These

organisations argue that legal owners of weapons are not the problem, citing statistics that support this position, such as the numbers of illegal guns in circulation and highlighting criminal activity with these weapons. ${ }^{352}$

\section{Regulating civilian possession of small atms in relation to the Arms Trade Treaty}

Though it has many critics, a few states and several NGOs continue to promote the norm of regulating civilian possession with regard to the ATT. States responded to the challenge of what should be included in an Arms Trade Treaty in the $\mathrm{A} / 62 / 278$ series of reports and in these submissions, five states specifically mentioned the need to regulate or increase regulation of civilian possession. ${ }^{353} \mathrm{~A}$ small number of states also mentioned the norm in other Treaty settings prior to the first PrepCom. ${ }^{354}$ During the first PrepCom itself, only one state - Mexico promoted the norm directly, revealing its lack of broad support in the face of

\footnotetext{
${ }^{352}$ This argument overlooks the link between the legal market and the illegal market, or downplays it where it is acknowledged. Biting the Bullet Project, Reviewing Action on Small Arms 2006: Assessing the First Five Years of the UN Programme of Action, 99; Greene and Kirkham, Preventing Diversion of Small Arms and Light Weapons: Issues and Priorities for Strengthened Controls; "IANSA Director in Gun Debate with the NRA."

${ }^{353}$ United Nations General Assembly, Towards an Arms Trade Treaty: Establishing Common International Standards for the Import, Export and Transfer of Conventional Arms.; United Nations General Assembly, Towards an Arms Trade Treaty: Establishing Common International Standards for the Import, Export and Transfer of Conventional Arms.; United Nations General Assembly, Towards an Arms Trade Treaty: Establishing Common International Standards for the Import, Export and Transfer of Conventional Arms. (Addendum); United Nations General Assembly, Towards an Arms Trade Treaty: Establishing Common International Standards for the Import, Export and Transfer of Conventional Arms. (Addendum); United Nations General Assembly, Towards an Arms Trade Treaty: Establishing Common International Standards for the Import, Export and Transfer of Conventional Arms. (Addendum); United Nations General Assembly, Towards an Arms Trade Treaty: Establishing Common International Standards for the Import, Export and Transfer of Conventional Arms. (Addendum).

${ }^{354}$ United Nations Institute for Disarmament Research (UNIDIR) and European Union, "Promoting Discussion on an Arms Trade Treaty - European Union-UNIDIR Project Regional Seminar for Countries in Eastern and Southern Africa. Summary Report"; United Nations Institute for Disarmament Research (UNIDIR) and European Union, "Promoting Discussion on an Arms Trade Treaty - European Union-UNIDIR Project. Summary Report.”
} 
continuing strong opposition. ${ }^{355}$ The chair of the PrepCom, Ambassador Moritán, released the Chairman's Draft Principles on July 14, which ignited the debate among states about the subject, because it noted in paragraph seven:

Recognising the right of States to regulate internal transfers of arms and national ownership, including through national constitutional protections on private ownership, exclusively within their territory... ${ }^{356}$

Regulation of internal weapons transfers and private possession of weapons are regarded intrinsically national concerns, not usually subject to international scrutiny. During the closed session on the scope of an ATT, states discussed such restrictions and the proposal to allow 'exceptions' to the Treaty for "internal transfers", "national ownership and regulation" and "sporting and hunting rifles for recreational purposes". ${ }^{357}$ The result of these discussions was that the 2010 Chairman's Draft Paper included a subsection of scope for exclusions ${ }^{358}$, and an almost verbatim paragraph from the Chairman's Draft Principles on regulation of civilian ownership and internal transfers. ${ }^{359}$ This reinforced the position of those who sought to strip any reference to regulating civilian possession from the Treaty, and shows that the norm is not likely to remain within the ATT cluster. What explains this absence?

\section{Opposition to the norm regulating civilian possession}

States that oppose the inclusion of the norm regulating civilian possession do so for two broad reasons. The first, which has been used by the US, is that their

\footnotetext{
355 The NRA-ILA website reports that the Netherlands also supports this norm; however I cannot find a specific mention of this position in my notes or in submissions. National Rifle Association of America (NRA), 'NRA-ILA: NRA-ILA Protects Gun Owners' Rights During UN Arms Trade Treaty Meeting."

${ }^{356}$ Moritán, “Chairman's Draft Principles.” Emphasis in original.

${ }^{357}$ Charles, "Facilitator's Summary for Scope."

${ }^{358}$ Moritán, “Chairman’s Draft Paper - 22 July 2010.” Elements, 5c.

${ }^{359}$ Ibid. Principles, para 12. The paragraph contains virtually identical phrasing but appears later in the document.
} 
constituents have the right to maintain their individual freedom and to own weapons. The second reason offered by states is that they object to regulating a domestic issue at the international level. In some cases, both reasons are given by states for their opposition to the norm. Several clearly stated at the first PrepCom that some 'civilian uses' of arms ought to be allowed and that regulation of "domestic gun ownership" is not an objective of the Treaty in their view. ${ }^{360}$ New Zealand commented on the need to include the "right to regulate internal transfers as well as the ownership and possession of arms within states' territory", and suggested that a section entitled "Exclusions" be introduced into the scope of the Treaty. ${ }^{361}$ This would allow certain types of possession, sale and use to be exempt from international scrutiny. There are several interest groups and NGOs in New Zealand that are putting pressure on the government to retain their freedom to possess small arms. ${ }^{362}$ There are similar groups in other states that are also placing their political representatives under heavy pressure to prevent the norm being included in the ATT. Many states did not mention the norm at all at the first PrepCom because of the strong stance taken by the United States against the norm and the Treaty. ${ }^{363}$ They have been unwilling to undermine talks by discussing regulating civilian possession

\footnotetext{
${ }^{360}$ Author's notes from PrepCom Day 1, afternoon session; Author's notes from Day 2, morning session; Author's notes from PrepCom Day 3, morning session; Author's notes from PrepCom Day 3, afternoon session; Author's notes from PrepCom Day 4, morning session; Bauwens, "Statement by H.E. Mr Werner Bauwens, Special Envoy for Disarmament and Non-Proliferation, European Union. EU Statement on the Goals and Objectives of an ATT."

${ }^{361}$ Author's notes from PrepCom Day 3, afternoon session; Higgie, "Statement by Ambassador Dell Higgie, Permanent Representative to the United Nations in Geneva, New Zealand." Israel questioned the need for this section. Author's notes from PrepCom Day 4, morning session.

${ }^{362}$ Council of Licensed Firearms Owners (COLFO) Inc., "Chairman's Report 2008-2009: NZ Council of Licensed Firearms Owners Inc, Report of the Board of Management 2008 - 2009"; "Council of Licensed Firearms Owners (COLFO) Inc. - About COLFO."

${ }^{363}$ Cukier et al., Regulation of Civilian Possession of Small Arms and Light Weapons.
} 
of weapons because they know the strong sentiments of the US on the issue and the power of the pro-gun lobby. ${ }^{364}$

In some ways the norm was always going to be a topic of discussion at the first ATT PrepCom, the proverbial 'elephant in the room', after the US' decision not to join negotiations in the beginning. ${ }^{365}$ This opposition to the norm was not unexpected, as a group of states also opposed the inclusion of this norm in the earlier Programme of Action. ${ }^{366}$ As a Permanent Member of the United Nations Security Council, the United States remains a very formidable state within the UN and its unwillingness to join the Treaty when it first emerged in 2006 was clear. The United States' resistance to debating the Treaty was based in large part on domestic pressure from pro-gun NGOs which contest the regulation of civilian possession norm, and in turn from supportive (predominantly Republican) politicians in the US. ${ }^{367}$ President George W. Bush has long supported gun rights and continued to do so during his term, when the idea of an ATT was first conceived. ${ }^{368}$ Bush said he supported the individual's right to possess firearms and refused to participate in discussions on the ATT because of this. Pro-gun NGOs publicise political and presidential candidates' statements on civilian possession of weapons, to enable their members to choose

\footnotetext{
${ }^{364}$ Author's observations from NGO meetings during the PrepCom; Garcia, Small Arms and Security: New Emerging International Norms, 161-162; Parliament of the United Kingdom, "Global Security: Non-Proliferation - Foreign Affairs Committee: Conventional Weapons. The Arms Trade Treaty (ATT)."

${ }^{365}$ The US delegate stated that the first PrepCom was not the time to be removing items from the agenda, although it noted that there were some issues which might not be supported by the US in the long run. Author's notes from Day 3, afternoon session; Author's notes from PrepCom Day 4, morning session.

${ }^{366}$ Capie, "Localization as Resistance: The Contested Diffusion of Small Arms Norms in Southeast Asia”; Garcia, Small Arms and Security: New Emerging International Norms, 172-173.

${ }^{367}$ Horwitz and Grimaldi, "NRA-led gun lobby wields powerful influence over ATF, U.S. politics"; Beauchamp, "Micro-Disarmament: Controlling Small Arms and Light Weapons and the International Security Agenda"; Grimaldi and Horwitz, "Industry Pressure Hides Gun Traces, Protects Dealers from Public Scrutiny”; Centre for Responsive Policy, “Open Secrets: Interest Groups - Gun Rights.”

${ }^{368}$ Centre for Responsive Policy, "Open Secrets: Interest Groups - Gun Rights.”
} 
which candidate they support in elections based on this stance. ${ }^{369}$ These groups are vocal and well-practised at responding to domestic small arms issues which could be used to push for greater regulation, such as the mass murders at Columbine High School and Virginia Tech. ${ }^{370}$ They are also well organised and have a clear message: regulation of the possession of SALW infringes on an individual right. These powerful pro-gun NGOs in the US reiterate the importance of the Second Amendment in the Bill of Rights and maintain pressure on political candidates. ${ }^{371}$ They argue that 'gun control' infringes on individual rights and reject much of the evidence offered to show the damage done by small arms, saying that the evidence is inaccurate, biased or incomplete. ${ }^{372}$ The NRA's President Wayne LaPierre stated, in a 2004 debate with former IANS A director Rebecca Peters, that the international small arms control process was "the UN's attempt to weaken our Second Amendment". ${ }^{373}$ At the first PrepCom, DSAAC's representative Major-General Youngman (Ret.) claimed that including civilian possession in the ATT would give "credibility to the suspicion ... that the true purpose of the treaty is domestic gun control [sic]". ${ }^{374}$ When President Barack Obama took office, lobbying continued from pro-gun

\footnotetext{
369 On the Issues, "George W. Bush on Gun Control."

${ }^{370}$ Birkland and Lawrence, "Media Framing and Policy Change after Columbine."

371 "IANSA Director in Gun Debate with the NRA"; LaPierre, "NRA-ILA: Why You Should Care About Brazil"; National Rifle Association of America (NRA), NRA: To See Where Gun Licensing Leads, Look To Great Britain. There are a number of pro-gun groups in the US including the National Shooting Sports Foundation (NSSF), The Second Amendment Foundation (SAF), the Sporting Arms and Ammunition Manufacturers' Institute (SAAMI) and DSAAC. See http://www.wfsa.net/members.html for links to these members of WFSA.

${ }^{372}$ Cummings and Miller, "Why The NRA Gets Its Way: Organization's Political Power Means Calls For Gun Control Will Likely Go Unheard”; Sporting Shooters' Association of Australia (SSAA), "Press Release: Claims by Anti-Gun Activists Shrill and Ignorant"; The International Coalition for Women in Shooting and Hunting (WiSH), "The International Coalition for Women in Shooting and Hunting (WiSH) - About WiSH."

373 "IANSA Director in Gun Debate with the NRA."

${ }^{374}$ Youngman, "Statement by the Defense Small Arms Advisory Council (DSAAC)."
} 
$\mathrm{NGOs}^{375}$, but eventually his administration agreed to discuss an ATT, although this announcement was limited by an addendum indicating that the US would join the discussion based on the rule of consensus - effectively giving it veto power over what it deemed unacceptable issues. ${ }^{376}$

There are other international, national and local pro-gun NGOs which reject attempts to include the norm regulating civilian possession of weapons in the ATT, providing a rival position to that of anti-gun NGOs. ${ }^{377}$ These pro-gun NGOs are able to successfully reframe the problems with small arms and civilian possession as resulting from 'criminals engaged in firearms violence and illegal firearms activities' rather than 'legal owners engaged in legitimate firearms activities'. In a similar way, they are also able to frame the problems as happening in other places or countries and therefore not 'our' problem. Canada has two vocal organisations which promote safe, legal civilian access to firearms: the Canadian Shooting Sports Association and the National Firearms Association. ${ }^{378}$ New Zealand has several pro-gun organisations including the National Rifle Association of New Zealand (NRANZ) and the Council of Licensed Firearms Owners (COLFO) $)^{379}$ and Australia also has organisations such as the Sporting Shooters' Association of Australia (SSAA) ${ }^{380}$, which advocate for the

${ }^{375}$ Grimaldi and Horwitz, "Industry Pressure Hides Gun Traces, Protects Dealers from Public Scrutiny"; Horwitz and Grimaldi, "NRA-led gun lobby wields powerful influence over ATF, U.S. politics"; National Rifle Association of America (NRA), "NRA-ILA: Election 2010 Recap - Gun Owners' Rights To Be Strengthened In Next Congress!”.

${ }^{376}$ Clinton, "U.S. Support for the Arms Trade Treaty"; Mohammed, "U.S. Reverses Stance on Treaty to Regulate Arms Trade."

${ }^{377}$ See the WFSA website, as above at fn. 371.

${ }^{378}$ Canadian Shooting Sports Association (CSSA), "Canadian Shooting Sports Association and Canadian Institute for Legislative Action"; National Firearms Association (Canada), "National Firearms Association - Canada's Most Effective Firearms Owners Association." The CSSA also has a legislative branch, the Canadian Institute for Legislative Action (CILA).

${ }^{379}$ Council of Licensed Firearms Owners (COLFO) Inc., "Council of Licensed Firearms Owners (COLFO) Inc. - About COLFO"; The National Rifle Association of New Zealand, "The National Rifle Association of New Zealand - Home Page."

${ }^{380}$ Sporting Shooters' Association of Australia (SSAA), "Sporting Shooters' Association of Australia." 
'gun rights' of their members. Many of these powerful NGOs are politically active on limiting regulation on civilian possession. For example, Canada's referendum on changes to its Long Gun Registry was held amid fierce lobbying against the proposed changed by pro-gun NGOs. ${ }^{381}$ These NGOs also have been allowed a political role; COLFO represented New Zealand at the third Biennial Meeting on the Programme of Action and WiSH represented Australia at this same meeting. ${ }^{382}$ Such groups also exist in other countries like Finland and Denmark, and actively lobby their Governments to ensure that legislative and regulatory restrictions on the civilian possession of weapons are minimal. They often link civilian possession to specific cultural and traditional practices, as mentioned earlier, to make changes to existing laws harder. Canada and New Zealand have a tradition of game hunting which is said to be part of the culture of rural life and a right enjoyed for many years. ${ }^{383}$ A related fact is that that there is a "variety of actors and uses" for these weapons, such as for competition shooting and by private security forces ${ }^{384}$, making it more difficult to argue that there is no use for them, as has been possible for other weapons. ${ }^{385}$ Powerful pro-gun NGOs are thus able to argue internationally and domestically that the norm misses its true target, or to successfully frame the norm as rejecting part of the national heritage. Because of this pressure, these states have continued to prevent the norm from gaining any traction at the Treaty debates against promotion of the norm regulating civilian possession by anti-gun NGOs.

\footnotetext{
${ }^{381}$ Hagen, "Vice-President's Corner: Democracy be Damned!".

${ }^{382}$ Council of Licensed Firearms Owners (COLFO) Inc., “Chairman's Report 2008-2009: NZ Council of Licensed Firearms Owners Inc, Report of the Board of Management 2008 - 2009"; Field and Game Federation of Australia Inc., "Field and Game Federation of Australia Newsletter."

${ }^{383}$ Howell, "Blood"; Hunter, Hunting : A New Zealand History.

${ }^{384}$ Indiscriminate weapons are prohibited under other international conventional weapons laws.

${ }^{385}$ Clarke, Transnational Advocacy Coalitions and Human Security Initiatives: Explaining Success and Failure, 5-6; Price, "A Genealogy of the Chemical Weapons Taboo"; Price, "Reversing the Gun Sights: Transnational Civil Society Targets Land Mines."
} 
In a similarly anti-regulation position, New Zealand's remark at the first PrepCom, which noted the state's right to regulate internal transfers, was supported by a number of other powerful states. Canada, the EU, Iran, Israel, and the United Kingdom all agreed that this issue is outside the purview of the Treaty, justifying their stance on the basis that non-intervention in domestic affairs is a cardinal principle of international politics. ${ }^{386}$ Thus in official discussions on the Arms Trade Treaty during 2010, the regulation of civilian possession continued to be politically controversial, with very few states supporting it and several states outright declaring that civilian possession is not an issue which should be included in the Treaty.

\section{Support for the norm regulating civilian possession of small arms}

Despite considerable opposition from powerful states and rival non-state groups, the nascent norm requiring regulation of civilian possession has been raised in ATT debates by a small number of states and several NGOs, including IANSA and the Biting the Bullet Project. Biting the Bullet published a 2003 paper on the issue, which suggested that such regulation of civilian possession was important to ensure human security because

... the civilian possession of weapons increases the risk of gun violence in a way that potentially infringes on individuals' freedom, their human rights and indeed sometimes their lives. ${ }^{387}$

This finding was based on rates of mortality among conflict and non-conflict populations, as well as the injuries sustained from small arms fire and from violence

\footnotetext{
${ }^{386}$ Author's notes from PrepCom Day 1, afternoon session; Author's notes from Day 2, morning session; Author's notes from PrepCom Day 3, morning session; Author's notes from PrepCom Day 3, afternoon session; Author's notes from PrepCom Day 4, morning session; Bauwens, "Statement by H.E. Mr Werner Bauwens, Special Envoy for Disarmament and Non-Proliferation, European Union. EU Statement on the Goals and Objectives of an ATT"; Higgie, "Statement by Ambassador Dell Higgie, Permanent Representative to the United Nations in Geneva, New Zealand"; Williams, "The 'Responsibility to Protect', Norm Localisation and African International Society."'

${ }^{387}$ Cukier et al., Regulation of Civilian Possession of Small Arms and Light Weapons.
} 
perpetrated under threat of small arms fire. ${ }^{388}$ With this in mind, NGOs like Gun Free South Africa, the Gun Control Network and Viva Rio continue to promote the norm, predominantly at the national level. ${ }^{389}$ However few states have promoted this norm regulating civilian possession of small arms with any vigour at the international level and in the ATT, in large part because they know that many powerful states and progun NGOs have taken a strong stance against the norm. ${ }^{390}$ States which had earlier supported the norm were deafeningly silent at the first PrepCom, giving the floor to those states which announced their desire to see the scope of the Treaty restricted to 'international issues' and those which objected to including this norm in the Treaty cluster. $^{391}$

The US had made its position on the norm clear in the lead up to the first PrepCom and its influence remains powerful, because it agreed to enter the negotiations on the basis of consensus. Requiring consensus with regard to the Treaty severely limits the likelihood of creating a strong and enforceable document in 2012 and the decision was much criticised by pro-disarmament NGOs. Because of the US' consensus position and the power of its national pro-gun NGOs, states which support the norm regulating civilian possession have proved reluctant to endorse this norm vigorously, as they are unwilling to jeopardise the whole Treaty

\footnotetext{
${ }^{388}$ Ibid.

${ }^{389}$ Gun Control Network, "Gun Control Network - Home"; Gun Free South Africa, "Gun Free South Africa: About Us"; Viva Rio, "Control Arms."

${ }^{390}$ Author's observations from NGO meetings and states during the PrepCom; Beauchamp, "MicroDisarmament: Controlling Small Arms and Light Weapons and the International Security Agenda"; Horwitz and Grimaldi, "NRA-led gun lobby wields powerful influence over ATF, U.S. politics"; Garcia, Small Arms and Security: New Emerging International Norms, 161-162; Garcia, "Making New International Norms: The Small Arms Case. BCSIA Discussion Paper 2003-13.”

${ }^{391}$ Author's observations from NGO meetings and states during the PrepCom; Greene and Kirkham, Preventing Diversion of Small Arms and Light Weapons: Issues and Priorities for Strengthened Controls, 24-27; "Caribbean Perspective: Sustainable Development and theArms Trade Treaty (ATT). Conference Outcome Document"; Beauchamp, "Micro-Disarmament: Controlling Small Arms and Light Weapons and the International Security Agenda."
} 
being derailed by insisting on its retention. The opposition of New Zealand, Australia and Canada to the inclusion of the norm in the ATT has also undermined its chances. These states openly and influentially endorse many other norms in the Treaty but have come out against this norm regulating civilian possession. This stance seriously weakens the norm's prospects, because both Canada and New Zealand are known for their pro-disarmament positions. Other pro-disarmament states like Norway have focussed on other issues like the inclusion of humanitarian law or victim assistance in the Treaty, and did not engage with the norm. This action has prevented the norm regulating civilian weapons possession reaching a tipping point and diffusing further, allowing the rival opposing norm to flourish.

The only state that openly supported the norm at the first PrepCom was Mexico, whose delegate indicated that all weapons should be included in the scope of the Arms Trade Treaty for regulation. ${ }^{392}$ Mexico's submission declared that decisions on transfers ought to include a consideration of the intended use, not just the intended user, and that "arms created for sports" or hunting are no different from military weapons due to the ease with which they can be modified. ${ }^{393}$ The Mexican position was clearly influenced by its proximity to the US and the struggles it has with illicit trafficking of drugs and SALW by criminal groups. ${ }^{394}$ There is an established trade of legally purchased weapons which are on-sold illegally - in a practice known as straw purchasing - and transported from the US to Mexico and

\footnotetext{
392 Author's notes from Day 2, morning session.

${ }^{393}$ Author's notes from Day 2, morning session; Delegation of Mexico, "Intervention of the Mexican Delegation Regarding the Basic Elements that Should be Included in the ATT." Some organisations dispute this statement. Youngman, "Statement by the Defense Small Arms Advisory Council (DSAAC)."

${ }^{394}$ Horwitz and Grimaldi, "NRA-led gun lobby wields powerful influence over ATF, U.S. politics"; "IANSA Director in Gun Debate with the NRA."
} 
other South American states. ${ }^{395}$ From there, they are used to devastating effect in conflicts with other gangs and with law enforcement. Some South American and Caribbean states voiced concerns about weak regulation on civilian possession, in light of the links made between the illicit trafficking of small arms and narcotics. ${ }^{396}$ None of them have publically called for civilian possession to be included in the face of the formidable opposition by other states and NGOs, and none of these states have the international clout to challenge the opposing norm with success.

Efforts to include the norm within the ATT norm cluster are failing because of the powerful opposition of the US and some traditionally pro-disarmament states but also because the few states and NGOs that are supportive of the comprehensive norm have not been able to create an effective and coherent message. These various norm entrepreneurs have not been able to harmonise their advocacy internationally, which has resulted in a weak presence in ATT meetings. Clarke argues that IANSA's policies have been affected by European governments' focus on illicit weapons trading rather than promoting regulation on all weapons. ${ }^{397}$ IANSA is largely supported with funding from European governments, which has at least an implicit effect on the focus of its campaigns but also on other pro-disarmament NGOs, because it is the dominant NGO campaigning globally on SALW. IANSA's global network helps to gain them perspective on the numerous issues associated with small arms use, but it also makes for a sweeping and potentially divergent advocacy agenda. NGOs such as Amnesty International and the Control Arms Campaign have aligned themselves with IANSA and with general regulation of small arms to prevent

\footnotetext{
${ }^{395}$ Fallis, "Virginia Gun Store D \& R Arms: Fastest from Counter to Crime."

${ }^{396}$ Epps, Towards Global Standards: Regional Experience in Small Arms Transfer Controls. Edited Papers from an International Seminar.

${ }^{397}$ Clarke, Transnational Advocacy Coalitions and Human Security Initiatives: Explaining Success and Failure, 10.
} 
continued armed violence, but have conflicting ideas about where the focus of their attention ought to be and how to go about regulating SALW. At the first ATT PrepCom in 2010, for example, a number of NGOs focussed on other issues, such as the inclusion of norms of human rights and victim assistance. They did not engage with civilian possession in any detail, spending time on other norms and unsuccessfully attempting to gain access to the closed sessions. ${ }^{398}$ The lack of clarity around civilian possession is a barrier to the norm's emergence because it cannot be easily communicated and makes framing the issue as a problem much harder. ${ }^{399}$ It makes opposition to powerful rival NGOs and their actions to prevent the norm regulating civilian possession emerging more difficult. Given the lack of strong norm promotion at the PrepCom ${ }^{400}$, and a lack of clarity about the norm itself, the norm regulating civilian possession has been unable to gain traction with regard to the Arms Trade Treaty.

\section{Conclusions}

The development of a norm regulating the civilian possession of small arms, in the Arms Trade Treaty norm cluster, has been slow due to a number of factors. The most prominent is the power of pro-gun NGOs, particularly in the United States, which has made states reluctant to raise the issue at the international level. Critics of the norm maintain that the real problem lies in the illicit possession of weapons by criminals or in states which have high rates of violence and disorder. They have

\footnotetext{
398 Author's observations from NGO meetings during the PrepCom.

${ }^{399}$ Clarke, Transnational Advocacy Coalitions and Human Security Initiatives: Explaining Success and Failure, 5-7; Finnemore and Sikkink, "International Norm Dynamics and Political Change," 897; Nadelmann, "Global Prohibition Regimes: the Evolution of Norms in International Society," 484485; Payne, "Persuasion, Frames and Norm Construction," 38-39.

${ }^{400}$ Author's observations from NGO meetings during the PrepCom; Author's notes from PrepCom Day 1, afternoon session; Author's notes from Day 2, morning session; Author's notes from PrepCom Day 3, morning session; Author's notes from PrepCom Day 3, afternoon session; Author's notes from PrepCom Day 4, morning session.
} 
successfully petitioned their respective governments for minimal levels of weapons regulation in order to allow civilians to participate in sport shooting or hunting. Moreover, states have been reluctant to allow international regulation of weapons possession and transfers as it is seen as interference in their domestic affairs. The 2011 Chairman's Draft Paper - from the second PrepCom - dropped reference to the norm and reiterated that a core principle of the Treaty will be that states have the right to regulate "internal transfers" and allow "national constitutional protections on private ownership". ${ }^{401}$ For these reasons, advocates for action regulating civilian possession of small arms have been unsuccessful in promoting this norm in the ATT.

${ }^{401}$ Moritán, “Chairman’s Draft Paper - 3 March 2010 [sic].” 


\section{Chapter Seven - Conclusions}

\section{The evolution of the Arms Trade Treaty norm cluster}

The Arms Trade Treaty norm cluster has evolved in discussions among states over the last five years, as norm entrepreneurs have sought to advance a range of goals. At time of writing, two of the three norms examined here - regulation of brokering and preventing weapons transfers to NSAs - are still part of the cluster of norms surrounding the ATT. Regulation of civilian possession has failed to emerge in the Arms Trade Treaty, after powerful states and NGOs linked together to prevent its emergence and promote the rival norm. The relationship between norms and their proponents (and opponents) can clearly be seen in the ATT process. Cooperation between like-minded states and NGOs has resulted in changes to how the two norms of regulating brokering and preventing transfers to NSAs are seen with regard to the Treaty but, conversely, it has also constrained movement with respect to the norm regulating civilian possession.

\section{Some answers to my research questions}

Small arms norms in the ATT norm cluster have been pressed by both NGOs and supportive states, with the three norms explored here noticeably evolving during debates. The analysis presented in this thesis suggests that NGOs and like-minded small and middle-powers were able get these norms on to the ATT agenda and into inter-governmental discussions, but the shape and content of the norm and progress from that point on was dependent on the support of powerful states, who had to be at least ambivalent rather than hostile to the norm concerned. This can be seen in the paths of the three different norms explored here. The norm regulating brokering of small arms began as a comprehensive, widely supported norm addressing the regulation of brokers and their activities. However, during debates it was 
transformed into a much narrower discussion about illicit brokering and questions over the efficacy of the norm for this goal. This change came as a result of the US and EU states moving their focus towards 'illicit transfers' more generally, to allow them the freedom to continue some SALW transfers. This was done because of concerns about terrorism post $9 / 11$ and a desire to continue profitable weapons exports.

The norm on preventing transfers to non-state groups has also been affected by a post-9/11 world. The norm shifted from an initial attempt to ban transfers to one that instead focussed attention on preventing diversion to 'unauthorised' NSAs, such as terrorists. This was because powerful states use NSAs to carry out covert foreign policy or seek to implicitly allow transfers to NSAs fighting regimes that are 'corrupt' or 'repressive'. Furthermore, this norm has lost ground within the ATT context, in 2011, because of difficulties in creating legislation which differentiates between different kinds of non-state actors.

Unsurprisingly, the norm regulating civilian possession was not strong enough to overcome the formidable objections of the US and an associated group of states supporting this position, including Canada and New Zealand, along with pressure from strong, organised NGOs like the NRA and its international counterparts. NGOs promoted a comprehensive norm to prevent human insecurity and armed violence, but states protested at what they perceived to be interference and regulation of their internal transfers and defended their citizens' right to possess firearms.

What was crucial for norm emergence in the ATT cluster? The analysis advanced here suggests that norm promotion by like-minded but less influential states and NGOs led small arms norms to be part of the agenda for international 
negotiations but that their goals were able to be contested and defeated by more powerful states and NGOs once the norms were under discussion at the ATT PrepCom. Organisations which were able to formulate simple and clear messages on the norm in question were more likely to be successful at retaining the norm in the ATT norm cluster, as were those which managed to convince powerful states of the legitimacy of their claims. NGOs were not able to wield a strong influence over the development of the norms in the cluster during the PrepCom, which offers important lessons for all NGOs working on global issues. It is a reminder of the salience of power in international relations, particularly with regard to security norms, and the limited ability of NGOs and like-minded minor states to influence normative emergence. Norms remained in the ATT norm cluster if they had the support of - or avoided hostility from - powerful states, which is a cautionary tale for normative theorists. The high expectations of governments and NGOs promoting small arms action in the prelude to the ATT negotiations were left in tatters by the positions of powerful states on the inclusion of some norms and on the formulation and content of others. The strong views of like-minded but comparatively weak states and NGOs were not enough to ensure the emergence of a norm.

Given the evolution of these three norms, it seems certain that none of them will remain in their original, more comprehensive form once the ATT is finalised. One, civilian possession, will be absent completely. The norm regulating brokering has moved sharply towards the narrower US and EU position of focussing solely on illicit transfers. Similarly, the norm preventing transfers to NSAs has evolved towards preventing transfers to 'illicit' NSAs, rather than all NSAs. ${ }^{402}$ The Arms Trade Treaty will remain a key focus for disarmament discussions at the

\footnotetext{
${ }^{402}$ Both of these changes appear in the 2011 'Chairman's Draft Paper'. Ibid.
} 
international level, but over the last five years the content, shape and strength of its norm cluster has shifted towards a narrow focus on the prevention of transfers that are illicitly brokered or transferred to illicit actors. It remains to be seen if this narrow approach to the structure and content of small arms norms is a permanent shift driven by power politics, that may have implications for other human security initiatives, or if pro-disarmament NGOs and like-minded states can rise to the challenge and develop strategies for advocacy on this issue to ensure that future small arms norms are comprehensive and robust. 


\section{Bibliography}

\section{Primary Sources}

Abelson, Annette. "Statement by Ms. Annette Abelson, Head of Delegation, Norway". New York, 2010.

Acharya, Amitav. "How Ideas Spread: Whose Norms Matter? Norm Localization and Institutional Change in Asian Regionalism." International Organisation 58, no. 2 (2004): 37.

Ackerman, Alice. "The Prevention of Armed Conflicts as an Emerging Norm in International Conflict Management: The OSCE and the UN as Norm Leaders." Peace and Conflict Studies 10, no. 1 (2003): 15.

Akram, Ambassador Zamir. "Statement by Ambassador Zamir Akram, Permanent Representative of Pakistan to the United Nations, Geneva, in the First Committee." 10. Geneva: United Nations, 2010.

Alpers, Philip, and Marcus Wilson. "Gun Policy: Facts and News." Gun Policy: International Firearm Injury Prevention and Policy, 2010. http://www.gunpolicy.org/.

Aly, Ambassador Hossam. "Facilitator's Summary on Implementation and Application”. New York: United Nations General Assembly, 2010.

Amnesty International. Amnesty International Report 2010: State of the World's Human Rights. The Report. London: Amnesty International, 2010. www.thereport.amnesty.org/en/.

. Blood at the Crossroads: Making the Case for a Global Arms Trade Treaty. London: Amnesty International, 2006.

. Dead on Time -Arms Transportation, Brokering and the Threat to Human Rights. Amnesty International, 2006.

- Deadly Movements: Arms Transportation Controls in the Arms Trade Treaty. London: Amnesty International, July 2010. www.amnesty.org/en/library/asset/ACT30/015/.../act300152010en.pdf. . "Italian Courts Release Arms Dealer." Terror Trade Times, May 11, 2003, Volume 4 edition. http://www.amnesty.org/en/library/asset/ACT31/002/2003/en/5f5d46e6d710-11dd-b0cc-1f0860013475/act310022003en.html.

Andean Community. Decision 552: Andean Plan to Prevent, Combat and Eradicate Illicit Trade in Small Arms and Light Weapons in all its Aspects (and Annexes), 2003.

Argentina, Australia, Costa Rica, Finland, Japan, Kenya, and United Kingdom. The Arms Trade Treaty (revised draft resolution). A/C.1/64/L.38/Rev.1, United Nations General Assembly. A/RES/64/48, 2010.

Argentina, Chile, Colombia, Guatemala, Jamaica, Mexico, Peru, Trinidad and Tobago, and Uruguay. "Joint Statement on Elements for a Treaty." 4. New York: United Nations, 2010. 
Asia-Pacific Economic Community. Bangkok Declaration on Partnership for the Future, 2003.

Bauwens, H.E. Mr Werner. "Statement by H.E. Mr Werner Bauwens, Special Envoy for Disarmament and Non-Proliferation, European Union. EU Statement on the Goals and Objectives of an ATT." 2. New York, 2010.

. "Statement by H.E. Mr Werner Bauwens, Special Envoy for Disarmament and Non-Proliferation, European Union. EU Statement on the Principles Governing the Arms Trade Treaty." 3. New York, 2010.

Beauchamp, Clive. "Micro-Disarmament: Controlling Small Arms and Light Weapons and the International Security Agenda." 18. Brisbane, Australia, 2008.

Birkland, Thomas A, and Regina G Lawrence. "Media Framing and Policy Change after Columbine." American Behavioural Scientist 52, no. 10 (June 2009): 21.

Biting the Bullet Project. Reviewing Action on Small Arms 2006: Assessing the First Five Years of the UN Programme of Action. Edited by Biting the Bullet Project. Biting the Bullet Project (International Alert, Saferworld and the University of Bradford) and International Action Network on Small Arms (IANSA), 2006.

Boon, Colonel Lim Yoon. "Statement of Colonel Lim Yoon Boon, Military Adviser, Permanent Mission of Singapore to the United Nations". New York, 2010.

Boutros-Ghali, Boutros. An Agenda for Peace: Preventive Diplomacy, Peacemaking and Peace-keeping. Report of the Secretary-General pursuant to the statement adopted by the Summit Meeting of the Security Council on 31 January 1992. Geneva: United Nations, June 17, 1992. http://www.un.org/Docs/SG/agpeace.html.

Boutwell, Jeffery, and Michael Klare. "A Scourge of Small Arms.” Scientific American 282, no. 6 (2000): 6.

Brunwasser, Matthew. "Gunrunners: Gallery of International Arms Dealers - Leonid Efimovich Minin.” PBS Frontline/World, May 2002. http://www.pbs.org/frontlineworld/stories/sierraleone/minin.html. . "Gunrunners: Gallery of International Arms Dealers - Monzer al Kassar." PBS Frontline/World, May 2002. http://www.pbs.org/frontlineworld/stories/sierraleone/alkassar.html. . "Gunrunners: Gallery of International Arms Dealers - Victor Anatoleyevich Bout.” PBS Frontline/World, May 2002. http://www.pbs.org/frontlineworld/stories/sierraleone/bout.html.

Butler, Christopher K, and Neill J Mitchell. "Non-State Actors, States, and Repression: The Effect of Militias and Informal Armed Groups on Human Rights Violations." Unpublished. University of New Mexico and University of Aberdeen, 2007.

http://www.unm.edu/ ckbutler/workingpapers/ButlerMitchell.pdf.

Cabactulan, Ambassador H.E. Mr Libran N. "Philippine Intervention on Agenda Item 7, Consideration of the implementation of the Programme of Action in 
all its aspects at the national, regional and global levels, including: a) The establishment, where appropriate, of regional and sub-regional mechanisms with a view to preventing, combating, and eradicating the illicit trade in small arms and light weapons across borders, including trans-border customs cooperation and networks for information-sharing among law enforcement, border and customs control agencies". New York: United Nations, 2008. http://www.poa-iss.org/bms3/Statements.html.

Cairns, Edmund. "Dying for Action: Decision Time for an Urgent, Effective Arms Trade Treaty." Oxfam Briefing Note, October 22, 2009. www.oxfam.org.

Canadian Shooting Sports Association (CSSA). "Canadian Shooting Sports Association and Canadian Institute for Legislative Action." Canadian Shooting Sports Association and Canadian Institute for Legislative Action, 2010. http://www.cdnshootingsports.org/.

Capie, David. "Armed Groups, Weapons Availability and Misuse: An Overview of the Issues and Options for Action. Background Paper for a Meeting Organized by the Centre for Humanitarian Dialogue.” 14. Bamako, Mali: Armed Groups Project, University of British Columbia and Relief Web, 2004. http://www.reliefweb.int/rw/lib.nsf/db900sid/LHON-

699FE8/\$file/Armed_Groups_Light_Weapons_AGP_May_2004.pdf?openele ment.

"Localization as Resistance: The Contested Diffusion of Small Arms Norms in Southeast Asia." Security Dialogue 39, no. 6 (2008): 22.

Caraley, Demetrious James. American Hegemony: Preventive War, Iraq, and Imposing Democracy. New York: Academy of Political Science, 2004.

Caribbean Community. "Statement on Behalf of CARICOM Member States by H.E. Henry MacDonald, Permanent Representative of Suriname to the United Nations at the First Session of the Preparatory Committee of the United Nations on the Arms Trade Treaty." New York: United Nations General Assembly, 2010.

"Caribbean Perspective: Sustainable Development and theArms Trade Treaty (ATT). Conference Outcome Document." 4. Antigua and Barbuda, 2008.

Centre for Responsive Policy. “Open Secrets: Interest Groups - Gun Rights”, 2010. http://www.opensecrets.org/industries/indus.php?ind=Q13.

Chabi, M Amine. "Statement by the Kingdom of Morocco by M. Amine Chabi, First Counsellor, Prepcom of the ATT." 2. New York: United Nations, 2010.

. "Statement of the Kingdom of Morocco on the Principles of a Future ATT, by M. Amine Chabi, First Counsellor, Prepcom of the ATT." 3. New York: United Nations, 2010.

http://www.un.org/disarmament/convarms/ATTPrepCom/StatementsMemberStates.html.

Charles, Ambassador Eden. "Facilitator's Summary for Scope”. New York: United Nations General Assembly, 2010.

Checkel, Jeffrey T. "Norms, Institutions, and National Identity in Contemporary Europe." International Studies Quarterly 43, no. 1 (1999): 32. 
"Review: The Constructivist Turn in International Relations Theory." World Politics 50, no. 2 (1998): 25.

Clarke, Warren. Transnational Advocacy Coalitions and Human Security Initiatives: Explaining Success and Failure. Waterloo: University of Waterloo and Hertie School of Governance, 2008.

Clinton, Secretary of State Hillary Rodham. "U.S. Support for the Arms Trade Treaty." U.S. Department of State: Diplomacy in Action, October 14, 2009. http://www.state.gov/secretary/rm/2009a/10/130573.htm.

Control Arms Campaign. Arms Without Borders: Why a Globalised Trade Needs Global Controls. Control Arms Campaign, October 2006.

-. The G8: Global Arms Exporters. Failing to Prevent Irresponsible Arms Transfers. Control Arms Campaign, June 22, 2005.

. Tracking Lethal Tools. Marking and Tracing Arms and Ammunition: A Central Piece of the Arms Control Puzzle. Control Arms Campaign, December 2004.

Cornish, Dr Paul. Arms Trade Treaty - Building Consensus and Making it Work. London: Chatham House (Royal Institute for International Affairs) and Royal College of Defence Studies, June 2, 2007.

Corsi, Jessica. "Towards Peace Through Legal Innovation: The Process and the Promise of the 2008 Cluster Munitions Convention." Harvard Human Rights Journal 22 (2009): 15.

Cortell, Andrew P, and James W Davis Jr. "How Do International Institutions Matter? The Domestic Impact of International Rules and Norms." International Studies Quarterly 40, no. 4 (1996): 28.

Council of Licensed Firearms Owners (COLFO) Inc. “Chairman's Report 20082009: NZ Council of Licensed Firearms Owners Inc, Report of the Board of Management 2008 - 2009." Council of Licensed Firearms Owners (COLFO) Inc., 2010. http://www.colfo.org.nz/index.php/news-/69-chairmans-report2008-2009.

. "Council of Licensed Firearms Owners (COLFO) Inc. - About COLFO." Council of Licensed Firearms Owners (COLFO) Inc., 2010. http://colfo.org.nz/index.php/about-colfo.

Council of the European Union. Council Joint Action of 12 July 2002 on the European Union's Contribution to Combating the Destabilising Accumulation and Spread of Small Arms and Light Weapons and Repealing Joint Action 1999/34/, 2002.

- EU Strategy to Combat Illicit Accumulation and Trafficking of SALW and Their Ammunition, 2006.

. European Code of Conduct on Arms Exports, 1998.

http://www.fas.org/asmp/campaigns/code/eucodetext.htm.

Cukier, Wendy, Derek Miller, Helena Vàzquez, and Charlotte Watson. Regulation of Civilian Possession of Small Arms and Light Weapons. Biting the Bullet Briefing Paper. Biting the Bullet Project (International Alert, Saferworld and 
the University of Bradford), 2003. http://www.international-

alert.org/pdf/BB_Briefing161.pdf.

Cummings, Jeanne, and David L Miller. "Why The NRA Gets Its Way:

Organization's Political Power Means Calls For Gun Control Will Likely Go Unheard." News. CBS News - Politics, April 18, 2007.

http://www.cbsnews.com/stories/2007/04/18/politics/politico/main2698141.s html.

Daniel, Lennox A. "Statement Delivered at the Open-Ended Working Group towards an Arms Trade Treaty (Concluding Session - March 6, 2009). Delivered by Mr Lennox A Daniel, Deputy Permanent Representative, Permanent Mission of Saint Vincent and the Grenadines to the United Nations." 2. New York: United Nations, 2009.

Degia, Mohammed Iqbal. "Intervention by Mr. Mohammed Iqbal Degia, First Secretary, Permanent Mission of Barbados to the United Nations on behalf of CARICOM, on the theme of Other issues, and identification of priority issues or topics of relevance in the illicit trade in small arms and light weapons in all its aspects and of their implementation challenges and opportunities". New York: United Nations, 2008. http://www.poaiss.org/bms3/Statements.html.

Delegation of Brazil. "Brazil: Statement on an Arms Trade Treaty". New York: United Nations, 2010.

Delegation of Indonesia. "Statement by Indonesia on 'Other Issues"'. New York: United Nations, 2008. http://www.poa-iss.org/bms3/Statements.html.

Delegation of Ireland. "Scope of a Potential Arms Trade Treaty." 1. New York: United Nations, 2009.

Delegation of Israel. "Statement made by Israel at the Preparatory Committee for the United Nations Conference on the Arms Trade Treaty." 3. New York: United Nations, 2010.

http://www.un.org/disarmament/convarms/ATTPrepCom/StatementsMemberStates.html.

Delegation of Mexico. "Intervention of the Mexican Delegation Regarding the Basic Elements that Should be Included in the ATT." 3. New York: United Nations, 2010. http://www.un.org/disarmament/convarms/ATTPrepCom/StatementsMemberStates.html.

Delegation of the Russian Federation. "Elements to be Discussed in the Context of a Potential ATT. Introductory Remarks by the Delegation of the Russian Federation.” 3. New York, 2010.

. "Proposals for the Inclusion into the Final Document of the Third Biannual Meeting of States to Consider the Implementation of the UN Programme of Action". New York: United Nations, 2008. http://www.poaiss.org/bms3/Statements.html.

. "Towards an Arms Trade Treaty - Goals and Objectives (Non-Paper)." 2.

New York, 2010. 
Delegation of Turkey. "Statement by the Delegation of Turkey at the First Meeting of the Open-Ended Working Group on Arms Trade Treaty." 1. New York: United Nations, 2009.

Delegation of Uruguay. "Presentation of the Uruguay Delegation: Preparatory Committee ATT, 12th to 23rd of July 2010". New York: United Nations, 2010.

Duggan, Mark. "More Guns, More Crime.” Journal of Political Economy 109, no. 51 (2001): 29.

Duncan, Ambassador John. "Open-Ended Working Group: Towards an Arms Trade Treaty. Intervention by Ambassador John Duncan, 4 March 2009. Scope of a Potential Arms Trade Treaty". New York: United Nations, 2009.

. "Statement by Ambassador John Duncan, UK Ambassador for Multilateral Arms Control Disarmament, on Principles of an Arms Trade Treaty." 2. New York: United Nations, 2010.

Economic Community of West African States (ECOWAS). Declaration of a Moratorium on Importation, Exportation and Manufacture of Light Weapons in West Africa, 1998.

—. ECOWAS Convention on Small Arms and Light Weapons, Their Ammunition and Other Related Materials, 2006.

_ . "Statement by Economic Community of West African States". New York, 2010.

Epps, Kenneth. Towards Global Standards: Regional Experience in Small Arms Transfer Controls. Edited Papers from an International Seminar. Waterloo: Project Ploughshares, February 8, 2007.

Erickson, Jennifer L. "When Do the Takers Become the Makers? The Promotion of 'Responsible Arms Trade' Norms”. Cornell University, April 3, 2008.

Fallis, David S. "Virginia Gun Store D \& R Arms: Fastest from Counter to Crime." Washington Post. Washington DC, October 25, 2010, Online edition, sec. Special Investigation: The Hidden Life of Guns. http://www.washingtonpost.com/wpdyn/content/article/2010/10/24/AR2010102402223.html.

Field and Game Federation of Australia Inc. "Field and Game Federation of Australia Newsletter". Field and Game Federation of Australia Inc., September 2008. http://www.sportingclays.org.au/Newletters/sept_08.pdf.

Finnemore, Martha, and Kathryn Sikkink. "International Norm Dynamics and Political Change.” International Organisation 52, no. 4 (1998): 31.

Florini, Ann. "The Evolution of International Norms.” International Studies Quarterly 40 (1996): 27.

Florquin, Nicholas, and Elisabeth Decrey Warner. "Engaging Non-State Armed Groups or Listing Terrorists? Implications for the Arms Control Community.” Disarmament Forum 1, no. Non-State Armed Groups (2008): 10 .

Frey, Barbara. Progress Report of Barbara Frey, Special Rapporteur on the Prevention of Human Rights Violations Committed with Small Arms and 
Light Weapons. Geneva and University of Minnesota: United Nations Commission on Human Rights, June 21, 2004.

http://www1.umn.edu/humanrts/demo/smallarms2004-2.html.

Gabelnick, Tamar, and Pamina Firchow. "UN Small Arms Conference: Evaluation and Prospects." Foreign Policy in Focus (June 1, 2001).

http://www.fpif.org/articles/un_small_arms_conference_evaluation_and_pros pects.

Garcia, Denise. "Making New International Norms: The Small Arms Case. BCSIA Discussion Paper 2003-13". Kennedy School of Government, Harvard University and Belfer Center for Science and International Affairs (BCSIA), April 2004.

"Norm Building in the Evolution of the Control of Small Arms in the International Agenda." Security and Defense Studies Review 5, no. 2 (2005): 31 .

. Small Arms and Security: New Emerging International Norms.

Contemporary Security Studies. New York and Oxon: Routledge, 2006.

Geneva Declaration Secretariat. "The Geneva Declaration on Armed Violence and Development". Geneva Declaration Secretariat, June 7, 2006. http://www.unhcr.org/refworld/publisher,GDS,,,494a3e7e2,0.html.

- The Global Burden of Armed Violence. Geneva: Geneva Declaration Secretariat, September 2008.

Glatz, Anne-Kathrin. "Norm Diffusion: Top Down or Bottom-Up? Small Arms Norms in El Salvador, South Africa and on the International Level." 48th Annual ISA Convention (2007).

Godnick, William. The Organisation of American States and the 2001 United Nations Conference on the Illicit Trade in Small Arms and Light Weapons in all Aspects: Tackling the Illicit Trade in Small Arms and Light Weapons. Biting the Bullet Project (International Alert, Saferworld and the University of Bradford), Project Ploughshares and The Arias Foundation for Peace and Human Progress, January 2002.

Godnick, William, and Helena Vàzquez. Small Arms Control in Latin America . International Alert, 2003.

Graduate Institute of International and Development Studies. Small Arms Survey 2002: Counting the Human Cost. Small Arms Survey Yearbook. Geneva: Graduate Institute of International and Development Studies, 2002.

—. Small Arms Survey 2009: Shadows of War. Small Arms Survey Yearbook. Cambridge and New York: Cambridge University Press, 2009.

- Small Arms Survey 2010: Gangs, Groups, and Guns. Small Arms Survey Yearbook. Cambridge and New York: Cambridge University Press, 2010.

Greene, Owen. "Examining International Responses to Illicit Arms Trafficking." Crime, Law and Social Change 33 (2000): 40.

Greene, Owen, and Elizabeth Kirkham. Preventing Diversion of Small Arms and Light Weapons: Issues and Priorities for Strengthened Controls. Biting the 
Bullet Policy Report. Biting the Bullet Project (International Alert, Saferworld and the University of Bradford), February 2009.

Greene, Owen, Charlotte Watson, and Elizabeth Kirkham. Developing International Norms to Restrict SALW Transfers to Non-State Actors. Biting the Bullet Project (International Alert, Saferworld and the University of Bradford), 2006.

http://www.smallarmssurvey.org/files/portal/issueareas/measures/Measur_pd f/BtB\%20CGP\%20NSAs.pdf.

Grimaldi, James V, and Sari Horwitz. "Industry Pressure Hides Gun Traces, Protects Dealers from Public Scrutiny." Washington Post. Washington DC, October 24, 2010, Online edition, sec. Special Investigation: The Hidden Life of Guns.

Gun Control Network. "Gun Control Network - Home." Gun Control Network, 2010. http://www.gun-control-network.org/GCN02.htm.

Gun Free South Africa. "Gun Free South Africa: About Us." Gun Free South Africa, 2010. http://www.gfsa.org.za/Home/Aboutus/tabid/1077/language/enUS/Default.aspx.

Haas, Ernst B. "Words Can Hurt You; Or, Who Said What to Who About Regimes." International Organisation 36, no. 2 (1982): 37.

Hagen, Blair. "Vice-President's Corner: Democracy be Damned!” Canadian Firearms Journal (November 2010): 2.

Haque, M. Shamsul. "Government Responses to Terrorism: Critical Views of Their Impacts on People and Public Administration." Public Administration Review 62, no. Special Issue (September 2002): 11.

Hetcher, Steven A. “The Music Industry's Failed Attempt to Influence File Sharing Norms." Vanderbilt Journal of Entertainment and Technology Law 7, no. 1 (2005 2004): 31.

Higgie, Ambassador Dell. "Statement by Ambassador Dell Higgie, Permanent Representative to the United Nations in Geneva, New Zealand". New York: New Zealand Mission to the United Nations, 2010.

Homayun, Jamilla. Brokers Without Borders: How Illicit Arms Brokers can Slip Through Gaps in the Pacific and International Arms Control System. Oxfam Case Study. New Zealand: Oxfam International, October 18, 2010.

Horn, Robert. "Cold Case - Viktor Bout: Arms and The Man." Time Asia, September 20, 2010.

http://www.time.com/time/magazine/article/0,9171,2017012,00.html.

Horwitz, Sari, and James V Grimaldi. "ATF's Oversight Limited in Face of Gun Lobby." Washington Post. Washington DC, October 26, 2010, Online edition, sec. Special Investigation: The Hidden Life of Guns. http://www.washingtonpost.com/wpdyn/content/article/2010/10/25/AR2010102505823.html.

. "NRA-led gun lobby wields powerful influence over ATF, U.S. politics." Washington Post. Washington DC, December 15, 2010, Online edition, sec. Special Investigation: The Hidden Life of Guns. 
http://www.washingtonpost.com/wpdyn/content/article/2010/12/14/AR2010121406045.html.

Howell, Colin D. "Blood." In Blood, Sweat, and Cheers: Sport and the Making of Modern Canada. Themes in Canadian Social History 6. Toronto and Buffalo: University of Toronto Press, 2001.

Hunter, Kathryn (Kate) M. Hunting : A New Zealand History. Auckland, New Zealand: Random House, 2009.

Husain, Neila. Armed and Dangerous: Small Arms and Explosives Trafficking in Bangladesh. South Asia Intelligence Review - Weekly Assessments \& Briefings. South Asia Terrorism Portal, October 14, 2002. http://satp.org/satporgtp/sair/Archives/1_13.htm\#assessment3.

"IANSA Director in Gun Debate with the NRA." International Action Network on Small Arms (IANSA), October 20, 2004. http://www.iansa.org/action/nra_debate.htm.

Inter-American Drug Abuse Control Commission. Model Regulations for the Control of the International Movement of Firearms, their Parts And Components and Ammunition - Updated, 2003.

Interior Ministers Council League of Arab States (General Secretariat). Arab Model Law on Weapons, Ammunitions, Explosives and Hazardous Material, 2002. http://www.international.gc.ca/informalmeetinggeneva2007/arab-model-lawen.asp.

International Commission of Inquiry (Rwanda). "Final Report of the International Commission of Inquiry (Rwanda) [S/1996/1096]”, November 18, 1998. http://www.rwandemb.org/un1.html.

International Committee of the Red Cross. Arms Transfer Decisions: Applying International Humanitarian Law. Practical Guide. International Committee of the Red Cross, June 2007.

International Crisis Group. "Illicit Arms in Indonesia." International Crisis Group, September 6, 2010. http://www.crisisgroup.org/en/publication-type/mediareleases/2010/asia/illicit-arms-in-indonesia.aspx.

International Peace Institute, and Herbert Wulf. Task Force One: Transnational Security Challenges - Small Arms \& Light Weapons. Non-Paper for Opening Plenary Meeting. IPI Task Forces on Strengthening Multilateral Security Capacity. International Peace Institute, April 1, 2008. http://www.wulfherbert.de/IPI\%20Non-Paper.pdf.

Johnson, Thomas H, and M. Christopher Mason. "All Counterinsurgency Is Local." The Atlantic, October 2008. http://www.theatlantic.com/magazine/archive/2008/10/all-counterinsurgencyis-local/6965/.

Karp, Aaron. Surplus Small Arms in South America. Small Arms Survey Working Paper. Geneva: Graduate Institute of International and Development Studies, 2009.

Kessler, Glenn. "Weapons Given to Iraq Are Missing - GAO Estimates 30\% of Arms Are Unaccounted For." Washington Post. Washington, August 6, 2006, 
Online edition. http://www.washingtonpost.com/wpdyn/content/article/2007/08/05/AR2007080501299.html.

Kistner, William. "Gunrunners: Gallery of International Arms Dealers - Sarkis Soghanalian." PBS Frontline/World, 2002.

http://www.pbs.org/frontlineworld/stories/sierraleone/soghanalian.html.

Krasner, Stephen. International Regimes. Cornell Studies in Political Economy. Ithaca and London: Cornell University Press, 1983.

Kytömäki, Elli, and Valerie Yankey-Wayne. Five Years of Implementing the United Nations Programme of Action on Small Arms and Light Weapons: Regional Analysis of National Reports. Geneva: United Nations Institute for Disarmament Research, 2006.

. Implementing the United Nations Programme of Action on Small Arms and Light Weapons: Analysis of Reports Submitted by States in 2003. Geneva: United Nations Institute for Disarmament Research, 2004.

Lahai, Honourable Dr Bernadette. "Statement made on the Occasion of the Preparatory Committee Meeting for the United Nations Conference on the Arms Trade Treaty, Frist Session, 12-23 July, 2010, by Hon Dr Bernadette Lahai (Chair, Parliamentarians for Global Action, Sierra Leone Chapter)." 2. New York: United Nations, 2010.

LaPierre, Wayne. "NRA-ILA: Why You Should Care About Brazil." National Rifle Association of America Institute for Legislative Action, February 2, 2006. http://www.nraila.org/Issues/Articles/Read.aspx?id=189\&issue=.

League of Arab States - Ministerial Council. Resolution 6447 on Arab Coordination for Combating the Illicit Trade in Small Arms and Light Weapons, 2004. http://www.smallarmssurvey.org/files/portal/issueareas/measures/Measur_pd f/Arab\%20League\%20Res\%206447.pdf.

. Resolution 6625 on Arab Coordination for Combating the Illicit Trade in Small Arms and Light Weapons, 2006.

http://www.smallarmssurvey.org/files/portal/issueareas/measures/Measur_pd f/Arab\%20League\%20Res\%206625.pdf.

Legro, Jeffrey W. "Which Norms Matter? Revisiting the 'Failure' of Internationalism.” International Organisation 51, no. 1 (1997): 33.

Ludwig, Jens, and Philip J Cook. "Public Policy Perspectives: Principles for Effective Gun Policy." Fordham Law Review 73 (2005 2004): 26.

Lumpe, Lora. "Curbing the Proliferation of Small Arms and Light Weapons." Security Dialogue 30, no. 2 (June 1999): 13.

Marsh, Nicholas, Cate Buchanan, Anne-Kathrin Glatz, Mireille Widmer, and Maria Karapetyan. "Overview of Governmental Statements Made at the Small Arms PrepCom”. New York: Small Arms Survey, Centre for Humanitarian Dialogue, International Peace Research Institute, Oslo, and Franciscans International, 2006.

Mohammed, Arshad. "U.S. Reverses Stance on Treaty to Regulate Arms Trade." Reuters, October 14, 2009. http://www.reuters.com/article/idUSTRE59E0Q920091015. 
Moir, Lindsay. The Law of Internal Armed Conflict. Cambridge Studies in International and Comparative Law 19. Cambridge: University of Cambridge Press, 2002.

Momen, Dr A.K. Abdul. "Statement by Dr A.K. Abdul Momen, Permanent Representative of Bangladesh to the United Nations". New York, 2010.

Moritán, Ambassador Roberto García. “Chairman's Draft Elements”. New York: United Nations General Assembly, 2010.

. “Chairman's Draft Paper - 22 July 2010”. New York: United Nations General Assembly, 2010.

“"Chairman's Draft Paper - 3 March 2010 [sic]." 10. New York: United Nations, 2011.

http://www.reachingcriticalwill.org/legal/att/prepcom2/docs/ChairDraft3March.pdf.

_. "Chairman's Draft Principles". New York: United Nations General Assembly, 2010.

Mouzos, Jenny. Firearm-Related Violence: The Impact of the Nationwide Agreement on Firearms. Australian Institute of Criminology: Trends \& Issues in Crime and Criminal Justice. Canberra, Australia: Australian Institute of Criminology, May 1999.

Muggah, Robert. Listening for a Change! Participatory Evaluations of DDR and Arms Reduction in Mali, Cambodia and Albania. Geneva: United Nations Institute for Disarmament Research, 2003. http://unidir.ch/pdf/ouvrages/pdf1-92-9045-176-9-en.pdf.

Nadelmann, Ethan A. "Global Prohibition Regimes: the Evolution of Norms in International Society." International Organisation 44, no. 4 (1990): 48.

National Firearms Association (Canada). 'National Firearms Association - Canada's Most Effective Firearms Owners Association." National Firearms Association, 2010. http://www.nfa.ca/.

National Rifle Association of America (NRA). NRA: To See Where Gun Licensing Leads, Look To Great Britain, 2007.

http://www.youtube.com/watch?v=TkS2BRoCd2I\&feature=related.

. 'NRA-ILA: Election 2010 Recap - Gun Owners' Rights To Be

Strengthened In Next Congress!" National Rifle Association of America Institute for Legislative Action, November 5, 2010.

http://www.nraila.org/Legislation/Federal/Read.aspx?id=6071.

. 'NRA-ILA: NRA-ILA Protects Gun Owners' Rights During UN Arms

Trade Treaty Meeting." National Rifle Association of America (NRA), July

23, 2010. http://www.nraila.org/Legislation/Federal/Read.aspx?id=5979.

Nevers, Renee de. "Imposing International Norms: Great Powers and Norm Enforcement.” International Studies Review 9 (2007): 28.

Nicaragua. "Working Paper Submitted by Nicaragua: Code of Conduct of Central American States on the Transfer of Arms, Ammunition, Explosives and Other Related Materiel (A/CONF.192/2006/RC/WP.6)." 5. New York: United Nations General Assembly, 2006. 
Norwegian Initiative for Small Arms Trade (NISAT). "An International Agenda on Small Arms and Light Weapons: Elements of a Common Understanding". Oslo: International Action Network on Small Arms (IANSA), 1998. www.nisat.org or www.iansa.org.

. "Elements of a Common Understanding". Oslo: International Action Network on Small Arms (IANSA), 1999.

O’Dwyer, Diane. "First Landmines, now Small Arms? The International Campaign to Ban Landmines as a Model for Small-Arms Advocacy." Irish Studies in International Affairs 17 (2006): 21.

Obisakin, Lawrence Olufemi. "Statement delivered by Lawrence Olufemi Obisakin, Minister, Permanent Mission of Nigeria to the UN." 2. New York, 2010.

. "Statement of the African Group delivered by Lawrence Olufemi Obisakin, Minister, Permanent Mission of Nigeria to the UN, at the First Session of the Preparatory Committee for the United Nations Conference on the Arms Trade Treaty." 3. New York: United Nations, 2010.

On the Issues. "George W. Bush on Gun Control." On the Issues: Every Political Leader on Every Issue, 2000.

http://www.ontheissues.org/George_W_Bush_Gun_Control.htm.

Organisation for Security and Cooperation in Europe (OSCE). OSCE Document on Small Arms and Light Weapons, 2000.

. "OSCE Handbook of Best Practices on Small Arms and Light Weapons.

Decision No. 5/03 Best Practice Guides on Small Arms and Light Weapons". Organisation for Security and Cooperation in Europe, 2003.

Organisation of American States. Inter-American Convention against the Illicit Manufacturing of and Trafficking in Firearms, Ammunition, Explosives, and Other Related Materials, 1997.

Ostrander, Jeremy. "Changing Direction on Non-Nuclear Arms Control? American Exceptionalism, Power and Constancy.” Berkeley Journal of International Law 21 (2003): 26.

Parker, Sarah. Analysis of States' Views on an Arms Trade Treaty. Geneva: United Nations Institute for Disarmament Research, 2007. http://www.unidir.ch/pdf/ouvrages/pdf-1-92-9045-008-A-en.pdf.

- Implications of States' Views on an Arms Trade Treaty. Geneva: United Nations Institute for Disarmament Research, 2008. www.unidir.ch/pdf/ouvrages/pdf-1-92-9045-008-B-en.pdf.

- National Implementation of the United Nations Small Arms Programme of Action and the International Tracing Instrument: An Analysis of Reporting in 2009-10 (Interim Version, June 2010). Small Arms Survey Working Paper. Geneva: Graduate Institute of International and Development Studies, June 2010.

Parker, Sarah, and Silvia Cattaneo. Implementing the United Nations Programme of Action on Small Arms and Light Weapons: Analysis of the National Reports Submitted by States from 2002 to 2008 (Draft Report). Geneva: United Nations Institute for Disarmament Research, July 2008. 
Parliament of the United Kingdom. "Global Security: Non-Proliferation - Foreign Affairs Committee: Conventional Weapons. The Arms Trade Treaty (ATT)." Parliamentary Business, 2008.

http://www.publications.parliament.uk/pa/cm200809/cmselect/cmfaff/222/22 210.htm\#a62.

Payne, Rodger A. "Persuasion, Frames and Norm Construction." European Journal of International Relations 7, no. 1 (2001): 25.

Permanent Mission of the Philippines to the United Nations. "Philippine Position on the Geneva Declaration on Armed Violence and Development". United Nations, May 29, 2009. http://www.un.org/disarmament/convarms/SALW/Docs/AVMemberStatesViews/Philippines-1.pdf.

Petlyakov, Sergey Y. "On the Activities of the Open-Ended Working Group (OEWG) to Address the Issues of the International Trade in Conventional Arms. Statement by Sergey Y Petlyakov (Russian Federation)." 4. New York: United Nations, 2009.

. "Regarding the Aims and Purposes of an International Arms Trade Treaty. Statement by Sergey Y Petlyakov (Russian Federation)." 4. New York: United Nations, 2009.

Petrasek, David, and Katherine Mann. Ends and Means: Human Rights Approaches to Armed Groups. Versoix, Switzerland: International Council on Human Rights Policy, 2001. http://www.ichrp.org/files/reports/6/105_report_en.pdf.

Policzer, Pablo, and Valerie Yankey-Wayne. Armed Groups and the Arms Trade Treaty: Challenges and Opportunities. Armed Groups Project Working Paper. Calgary, Canada: Armed Groups Project, Latin American Research Centre, University of Calgary, April 2009.

Price, Richard. "A Genealogy of the Chemical Weapons Taboo." International Organisation 49, no. 1 (1995): 31.

. "Reversing the Gun Sights: Transnational Civil Society Targets Land Mines." International Organization 52, no. 3 (1998): 32.

Programme of Action - Implementation Support System. "Statements - Member States." Third Biennial Meeting of States on Small Arms and Light Weapons, July 14, 2008. http://www.poa-iss.org/bms3/Statements.html.

Quinlan, Ambassador Gary Francis. "Facilitator's Summary on Parameters". New York: United Nations General Assembly, 2010.

Quintero, Nohra. "Statement by Mrs Nohra Quintero, Coordinator on Disarmament and International Security, Ministry of Foreign Affairs, Colombia: 'Other Matters"'. New York: United Nations, 2008. http://www.poaiss.org/bms3/Statements.html.

Rall, Ted. Gas War: The Truth Behind the American Occupation of Afghanistan. Lincoln, New England: iUniverse Inc, 2002.

Ramraj, Victor V., Michael Hor, and Kent Roach. Global Anti-Terrorism Law and Policy. New York: Cambridge University Press, 2005. 
Raymond, Gregory A. "Problems and Prospects in the Study of International Norms." Mershon International Studies Review 41, no. 2 (1997): 41.

Republic of Burundi, Democratic Republic of Congo, Republic of Djibouti, Federal Democratic Republic of Ethiopia, State of Eritrea, Republic of Kenya, Republic of Rwanda, et al. The Nairobi Protocol for the Prevention, Control and Reduction of Small Arms and Light Weapons in the Great Lakes Region and the Horn of Africa, 2004.

Reynolds, Julia, William Kistner, and Omar Lavieri. "Gunrunners: Gallery of International Arms Dealers - Jean Bernard Lasnaud.” PBS Frontline/World, May 2002.

http://www.pbs.org/frontlineworld/stories/sierraleone/lasnaud.html.

Richmond, T S, R Cheney, and C W Schwab. "The Global Burden of Non-Conflict Related Firearm Mortality.” Injury Prevention 11 (2005): 5.

Rittberger, Volker, and Peter Mayer. Regime Theory and International Relations. New York: Oxford University Press, 1993.

Segell, Glen M. “Terrorism: London Public Transport - July 7, 2005.” Strategic Insights IV, no. 8 (August 2005).

http://www.nps.edu/Academics/centers/ccc/publications/OnlineJourna1/2005/ Aug/segellAug05.html.

Shapiro, Andrew J. "Briefing on Pending Major Arms Sale." U.S. Department of State: Diplomacy in Action, October 20, 2010. http://www.state.gov/t/pm/rls/rm/149749.htm.

Sheridan, Mary Beth. "Despite Obama Pledge, Democrats Show Little Enthusiasm for CIFTA Treaty on Gun Trafficking." Washington Post. Washington, October 21, 2010, Online edition. http://www.washingtonpost.com/wpdyn/content/article/2010/10/21/AR2010102107266.html.

Snow, David A., E. Burke Rochford Jr., Steven K. Worden, and Robert D. Benford. "Frame Alignment Processes, Micromobilization, and Movement Participation." American Sociological Review 51, no. 4 (1986): 18.

South Pacific Chiefs of Police Conference (SPCPC) Working Group, and Pacific Islands Forum. "Nadi Framework: Legal Framework for a Common Approach to Weapons Control", March 10, 2000.

Southern African Development Community. Protocol on the Control of Firearms, Ammunition and Other Related Materials in the Southern African Development Community (SADC) Region, 2001.

Sporting Shooters' Association of Australia (SSAA). "Press Release: Claims by Anti-Gun Activists Shrill and Ignorant." Sporting Shooters' Association of Australia, August 24, 2010. http://www.ssaa.org.au/press-releases/2010-0824_claims-by-anti-gun-activists-shrill-and-ignorant.html.

_. "Sporting Shooters' Association of Australia." Sporting Shooters' Association of Australia, 2010. http://www.ssaa.org.au/.

Stohl, Rachel. "Questionable Reward: Arms Sales and the War on Terrorism." Arms Control Today 38, no. 1 (February 2008): 7. 
Stohl, Rachel, and Doug Tuttle. "The Small Arms Trade in Latin America." NACLA Report on the Americas 41, no. 2 (2008).

Stohl, Rachel, Michael Stohl, and Cynthia Stohl. "Linking Small Arms, Child Soldiers, NGOs and Citizen Diplomacy: Nicolas Cage and the Lord of War." Suntec City, Singapore: All Academic Inc and International Communication Association, 2010. http://www.allacademic.com/meta/p402186_index.html.

The Cluster Munition Coalition. "The Problem: What is the Oslo Process?" The Cluster Munition Coalition, 2010. http://www.stopclustermunitions.org/theproblem/.

The Fund for Peace. "Model Convention on the Registration of Arms Brokers and the Suppression of Unlicensed Arms Brokering." 12. New York: The Fund for Peace, 2001. www.fundforpeace.org.

The International Campaign to Ban Landmines. "Convention on Cluster Munitions: Ban History." The International Campaign to Ban Landmines, 2010. http://www.icbl.org/index.php/icbl/Treaties/CCM/Ban-History. . "Mine Ban Treaty: Ban History." The International Campaign to Ban Landmines, 2010. http://www.icbl.org/index.php/icbl/Treaties/MBT/BanHistory.

The International Coalition for Women in Shooting and Hunting (WiSH). "The International Coalition for Women in Shooting and Hunting (WiSH) - About WiSH." The International Coalition for Women in Shooting and Hunting (WiSH), 2010. http://www.ic-wish.org/aboutwish.htm.

The National Rifle Association of New Zealand. "The National Rifle Association of New Zealand - Home Page." National Rifle Association of New Zealand (Inc.), 2011. www.nranz.com.

United Nations Department for Disarmament Affairs. "Programme of Action to Prevent, Combat and Eradicate the Illicit Trade in Small Arms and Light Weapons in All Its Aspects". New York: United Nations General Assembly, 2001. http://disarmament.un.org/cab/poa.html.

United Nations Department for Disarmament Affairs, and The League of Arab States Department for Disarmament. "Co-Chair's Summary. Implementation, by the Arab States, of the United Nations Programme of Action on the Illicit Trade in Small Arms and Light Weapons." 7. Cairo: United Nations Department for Disarmament Affairs, 2003.

United Nations Development Programme. How to Guide: Small Arms and Light Weapons Legislation. Geneva: United Nations Development Programme, July 2004.

United Nations Economic and Social Council. Criminal Justice Reform and Strengthening of Legal Institutions: Measures to Regulate Firearms (and Annexes). Report of the UN Secretary-General. Geneva: United Nations Economic and Social Council, March 7, 1997.

. Firearm Regulation for Purposes of Crime Prevention and Public Health and Safety, 1997. 
United Nations General Assembly. Convention against Transnational Organised Crime, 2000.

http://www.unodc.org/documents/treaties/UNTOC/Publications/TOC\%20Co nvention/TOCebook-e.pdf.

- Convention on Prohibitions or Restrictions on the Use of Certain

Conventional Weapons Which May Be Deemed to Be Excessively Injurious or to Have Indiscriminate Effects (and Protocols), 1980.

http://www.icrc.org/Web/Eng/siteeng0.nsf/htmlall/p0811/\$File/ICRC_002_0 811.PDF.

. Convention on the Prohibition of the Use, Stockpiling, Production and

Transfer of Anti-Personnel Mines and on Their Destruction (Ottawa

Convention), 1997. http://www.icbl.org/index.php/icbl/Treaties/MBT/TreatyText-in-Many-Languages/English.

. General and Complete Disarmament: Consolidation of Peace through

Practical Disarmament Measures. A/RES/51/45 N, 1997.

. General and Complete Disarmament: Small Arms. A/RES/50/70 B, 1996.

General and Complete Disarmament: Small Arms (Report of the Panel of

Governmental Experts on Small Arms). A/52/298 and Annex, 1997.

- General and Complete Disarmament: Small Arms. Report of the Group of

Governmental Experts on Small Arms. United Nations, August 19, 1999.

-. General and Complete Disarmament: The Illicit Trade in Small Arms and

Light Weapons in all its Aspects. A/RES/56/24 V, 2002.

. General and Complete Disarmament: Transparency in Armaments, 1991.

- Geneva Conventions (and Additional Protocols), 1949.

http://www.icrc.org/Web/Eng/siteeng0.nsf/html/genevaconventions.

Information on Confidence-Building Measures in the Field of Conventional Arms. A/RES/60/82, 2006.

. International Instrument to Enable States to Identify and Trace, in a Timely and Reliable Manner, Illicit Small Arms and Light Weapons, 2005.

http://disarmament.un.org/cab/docs/International\%20instrument\%20English. pdf.

Preventing and Combatting Illicit Brokering Activities. Vol. A/RES/65/75, 2010. http://www.un.org/en/ga/65/resolutions.shtml;

http://www.un.org/ga/search/view_doc.asp?symbol=A/65/410.

- Protocol against the Illicit Manufacturing of and Trafficking in Firearms, Their Parts and Components and Ammunition, supplementing the United Nations, 2001. http://www.unodc.org/pdf/crime/a_res_55/255e.pdf.

. Report of the Disarmament Commission (Guidelines for International Arms Transfers in the Context of General Assembly Resolution 46/36 H of 6 December 1991), April 24, 1996.

. Report of the Group of Governmental Experts Established Pursuant to General Assembly Resolution 60/81 to Consider Further Steps to Enhance International Cooperation in Preventing, Combating and Eradicating Illicit 
Brokering in Small Arms and Light Weapons. Geneva: United Nations General Assembly, August 3, 2007.

Report of the Group of Governmental Experts to Examine the Feasibility, Scope and Draft Parameters for a Comprehensive, Legally Binding Instrument Establishing Common International Standards for the Import, Export and Transfer of Conventional Arms. Geneva: United Nations General Assembly, August 26, 2008.

. "Report of the Open-Ended Working Group towards an Arms Trade Treaty: Establishing Common International Standards for the Import, Export and Transfer of Conventional Arms". New York: United Nations, 2009.

. Report of the Third Biennial Meeting of States to Consider the Implementation of the Programme of Action to Prevent, Combat and Eradicate the Illicit Trade in Small Arms and Light Weapons in All Its Aspects. New York: United Nations, August 20, 2008.

. Study on Ways and Means of Promoting Transparency in International Transfers of Conventional Arms. Geneva: United Nations General Assembly, September 9, 1991.

- Towards an Arms Trade Treaty: Establishing Common International Standards for the Import, Export and Transfer of Conventional Arms. Vol. A/RES/61/89, 2006.

Towards an Arms Trade Treaty: Establishing Common International Standards for the Import, Export and Transfer of Conventional Arms., 2007.

. Towards an Arms Trade Treaty: Establishing Common International Standards for the Import, Export and Transfer of Conventional Arms., 2007.

. Towards an Arms Trade Treaty: Establishing Common International Standards for the Import, Export and Transfer of Conventional Arms. (Addendum), 2007.

- Towards an Arms Trade Treaty: Establishing Common International Standards for the Import, Export and Transfer of Conventional Arms. (Addendum), 2007.

. Towards an Arms Trade Treaty: Establishing Common International Standards for the Import, Export and Transfer of Conventional Arms. (Addendum), 2007.

- Towards an Arms Trade Treaty: Establishing Common International Standards for the Import, Export and Transfer of Conventional Arms. (Addendum), 2008.

. Towards an Arms Trade Treaty: Establishing Common International Standards for the Import, Export and Transfer of Conventional Weapons. A/RES/63/240, 2009.

United Nations Institute for Disarmament Research (UNIDIR), and European Union. "Promoting Discussion on an Arms Trade Treaty - European Union-UNIDIR Project Regional Seminar for Countries in Central, Northern and Western Africa. Summary Report.” 22. Dakar, Senegal: United Nations Institute for Disarmament Research (UNIDIR) and European Union, 2009. 
"Promoting Discussion on an Arms Trade Treaty - European UnionUNIDIR Project Regional Seminar for Countries in Eastern and Southern Africa. Summary Report." 23. Addis Ababa, Ethiopia: United Nations Institute for Disarmament Research (UNIDIR) and European Union, 2009.

. "Promoting Discussion on an Arms Trade Treaty - European UnionUNIDIR Project Regional Seminar for Countries in the Americas and the Caribbean. Summary Report." 26. Mexico City, Mexico: United Nations Institute for Disarmament Research (UNIDIR), European Union and Ministry of Foreign Affairs, Mexico, 2009.

. "Promoting Discussion on an Arms Trade Treaty - European UnionUNIDIR Project Regional Seminar for Countries in the Middle East. Summary Report.” 23. Amman, Jordan: United Nations Institute for Disarmament Research (UNIDIR) and European Union, 2009.

. "Promoting Discussion on an Arms Trade Treaty - European UnionUNIDIR Project Regional Seminar for Wider Europe. Summary Report.” 18. Vienna, Austria: United Nations Institute for Disarmament Research (UNIDIR), European Union and Austrian Federal Ministry for European and International Affairs, 2010.

. "Promoting Discussion on an Arms Trade Treaty - European UnionUNIDIR Project. Summary Report.” 11. Vienna, Austria: United Nations Institute for Disarmament Research (UNIDIR), European Union and Austrian Federal Ministry for European and International Affairs, 2010.

United Nations Security Council. United Nations Security Council Resolution 1013, 1995. http://www.mtholyoke.edu/acad/intrel/unamir5.htm.

—. United Nations Security Council Resolution 1269. Vol. 1269, 1999.

—. United Nations Security Council Resolution 1373. Vol. 1373, 2001. http://www.un.org/Docs/scres/2001/sc2001.htm.

—. United Nations Security Council Resolution 1540. Vol. 1540, 2004. http://www.reachingcriticalwill.org/political/SC/1540.pdf.

United Nations. "Text and Status of the United Nations Conventions on Terrorism." United Nations Treaty Collection, 2010.

http://untreaty.un.org/English/Terrorism.asp.

- The Charter of the United Nations, 1945. http://www.un.org/en/documents/charter/.

United States of America. "The National Security Strategy of the United States of America". United States of America, September 2002. http://www.au.af.mil/au/awc/awcgate/nss/nss_sep2002.pdf.

—. Uniting and Strengthening America by Providing Appropriate Tools Required to Intercept and Obstruct Terrorism (USA PATRIOT ACT) Act of 2001. Vol. 3162, 2001. http://epic.org/privacy/terrorism/hr3162.pdf.

United States of America v. Monzer al-Kassar, Tareq Mousa Al Ghazi, and Luis Felipe Moreno-Godoy, Defendants (United States District Court, Southern District New York. 2008). 
United States of America v. Viktor Bout, a/k/a "Boris," : a/k/a "Victor Anatoliyevich Bout,": a/k/a "Victor But,": a/k/a "Viktor Budd," : a/k/a "Viktor Butt,": a/k/a "Viktor Bulakin," : a/k/a "Vadim Markovich Aminov," and Andrew Smulian, : Defendants. United States of America : Sealed Complaint: Violations of Title 18, United States Code, Sections 2339B \& 3238 (United States District Court, Southern District New York 2008).

Vasiliev, Victor. "Statement by Mr Victor Vasiliev, Alternate Head of the Russian Delegation to the First Committee of the 64th Session of the UN General Assembly. Explanation of Vote on the Draft Resolution L.38 'Towards an Arms Trade Treaty: Establishing Common International Standards for the Import, Export and Transfer of Conventional Arms'.” 3. New York: United Nations, 2009.

Viva Rio. "Control Arms." Viva Rio, October 20, 2002. http://www.vivario.org.br/publique/cgi/cgilua.exe/sys/start.htm?infoid=152\& sid=31\&UserActiveTemplate=_vivario_en.

Wassenaar Arrangement Secretariat. The Wassenaar Arrangement on Export Controls for Conventional Arms and Dual-Use Goods and Technologies. Basic Documents, 2009.

Wetzels, Peter. "Family Violence in the United States and Abroad, Guns at Home, Guns on the Street: An International Perspective." New York Law School Journal of International and Comparative Law 15 (1995 1994): 6.

Wieland, Christoph. "Statement on Behalf of Austria by Mr. Christoph Wieland, Counsellor at the Austrian Mission to the UN." 3. New York: United Nations, 2010.

Williams, Deon Lloyd. "Statement by Mr Deon Lloyd Williams, Counsellor, Permanent Mission of Jamaica to the United Nations". New York, 2010.

Williams, Paul D. "The 'Responsibility to Protect', Norm Localisation and African International Society." Global Responsibility to Protect 1 (2009): 25.

Yanai, Keiko. "Statement on 'Goals and Objectives of a Feasible Arms Trade Treaty' by Ms Keiko Yanai, Ministry of Foreign Affairs, Japan.” 3. New York: United Nations General Assembly, 2009.

Yankey-Wayne, Valerie. "Widening Our Understanding of the Brokering Issue: Key Developments." In Developing a Mechanism to Prevent Illicit Brokering in Small Arms and Light Weapons-Scope and Implications. Geneva: United Nations Institute for Disarmament Research (UNIDIR), 2007.

Youngman, Major-General (Ret) D. Allen. "Statement by the Defense Small Arms Advisory Council (DSAAC).” 2. New York: United Nations, 2010. 